Prepared in cooperation with the Trinity River Restoration Project

\title{
Assessing Geomorphic Change along the Trinity River Downstream from Lewiston Dam, California, 1980 to 2011
}

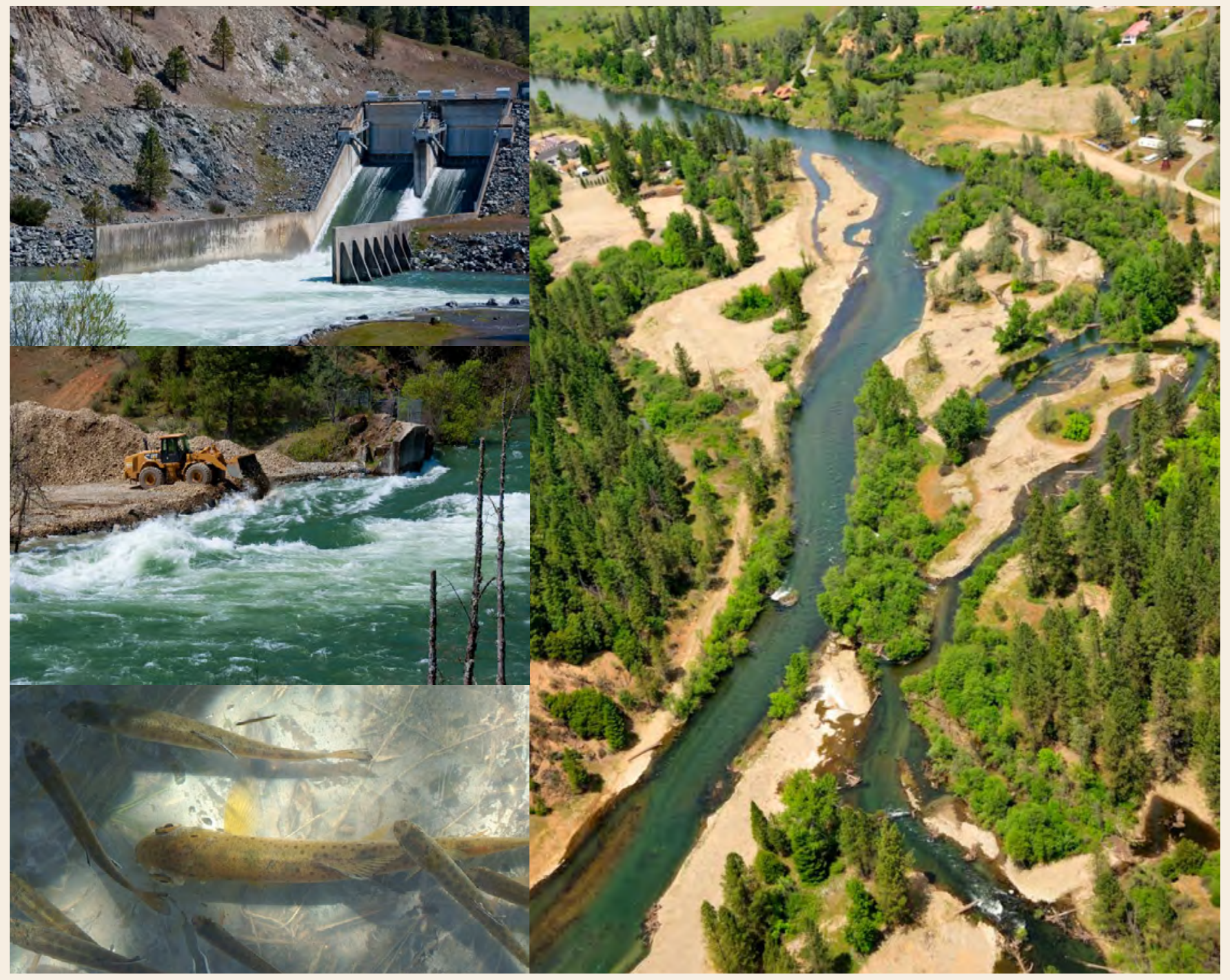

Scientific Investigations Report 2015-5046 
Cover: Photo mosaic showing 2011 peak flow release from Lewiston Dam and concurrent gravel augmentation at Lewiston gaging station (1.5 floodplain kilometers downstream from Lewiston Dam). Sawmill rehabilitation site and juvenile coho, 4 floodplain kilometers downstream from Lewiston Dam. Photo credit: Trinity River Restoration Program on-line photo archives. 


\section{Assessing Geomorphic Change along the Trinity River Downstream from Lewiston Dam, California, 1980 to 2011}

By Jennifer A. Curtis, Scott A. Wright, J. Toby Minear, and Lorraine E. Flint

Prepared in cooperation with the Trinity River Restoration Program

Scientific Investigations Report 2015-5046 


\title{
U.S. Department of the Interior SALLY JEWELL, Secretary
}

\section{U.S. Geological Survey Suzette M. Kimball, Acting Director}

\author{
U.S. Geological Survey, Reston, Virginia: 2015
}

For more information on the USGS - the Federal source for science about the Earth, its natural and living resources, natural hazards, and the environment—visit http://www.usgs.gov or call 1-888-ASK-USGS.

For an overview of USGS information products, including maps, imagery, and publications, visit http://www.usgs.gov/pubprod/.

Any use of trade, firm, or product names is for descriptive purposes only and does not imply endorsement by the U.S. Government.

Although this information product, for the most part, is in the public domain, it also may contain copyrighted materials as noted in the text. Permission to reproduce copyrighted items must be secured from the copyright owner.

Suggested citation:

Curtis, J.A., Wright, S.A., Minear, J.T., and Flint, L.E., 2015, Assessing geomorphic change along the Trinity River downstream from Lewiston Dam, California, 1980-2011: U.S. Geological Survey Scientific Investigations Report 2015-5046, 69 p., plus appendix, http://dx.doi.org/10.3133/sir20155046.

ISSN 2328-0328 (online) 


\section{Contents}

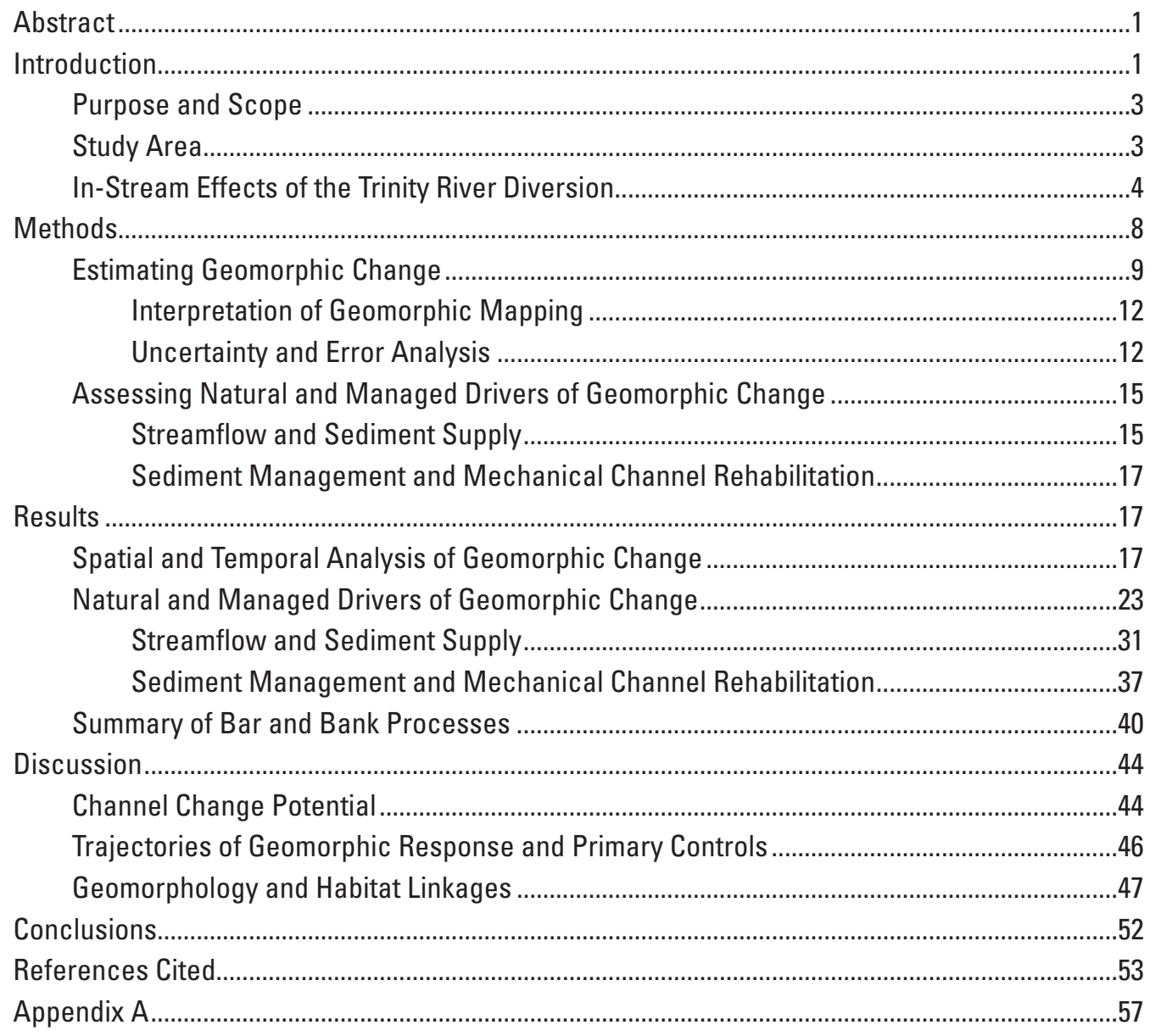




\section{Figures}

1. Map showing study area, Trinity River, California

2. Map showing Trinity River restoration reach, in California, from Lewiston Dam downstream to the North Fork Trinity confluence and 13 geomorphic reaches, within 3 river-channel segments, used as the spatial framework for interpretation of mapping results

3. Graph showing elevation profile of the Trinity River restoration reach, California, estimated from 10-meter-resolution digital elevation data..

4. Raster hydrograph showing mean daily flows measured 1.5 kilometers downstream from Lewiston Dam along the Trinity River, California.

5. Photo showing example of the topographic relations among depositional and constructed features for the Trinity River downstream from Lewiston Dam, California

6. Graphs showing areal extent of riparian and channel features along the Trinity River downstream from Lewiston Dam, California, $A$, in 1980, and change in active-channel area for five periods from 1980 to 2011: $B, 1980$ to $1997 ; C, 1997$ to 2001; D, 2001 to 2006; $E, 2006$ to 2009; and $F, 2009$ to 2011.

7. Bar graphs showing areal extent of lower elevation riparian features along the Trinity River downstream from Lewiston Dam, California, in $A, 1980 ; B, 1997$; $C, 2001 ; D, 2006 ; E, 2009$; and $F, 2011$

8. Bar graphs showing areal extent of channel-complexity features within the active channel along the Trinity River downstream from Lewiston Dam, California, in $A, 1980 ; B, 1997 ; C, 2001 ; D, 2006 ; E, 2009 ;$ and $F, 2011$

9. Graphs showing area of uplands along the Trinity River downstream from Lewiston Dam, California, and change in upland area from 1980 to 2011: $A$, cumulative area by reach; $B$, cumulative change in area per year by reach; $C$, area by study reach and segments over time.

10. Graphs showing area of riparian features along the Trinity River downstream from Lewiston Dam, California, and change in riparian area from 1980 to 2011: $A$, cumulative area by study reach; $B$, cumulative change in area per year by study reach; $C$, area by study reach and segments over time...

11. Graphs showing area of the pre-dam floodplain along the Trinity River downstream from Lewiston Dam, California, and change in pre-dam floodplain area from 1980 to 2011: $A$, cumulative area by study reach; $B$, cumulative change in area per year by study reach; $C$, area by study reach and river segments over time.

12. Graphs showing area of post-dam benches along the Trinity River downstream from Lewiston Dam, California, and change in post-dam bench area from 1980 to 2011: $A$, cumulative area by study reach; $B$, cumulative change in area per year by study reach; $C$, area by study reach and river segments over time.

13. Graphs showing area of constructed floodplains along the Trinity River downstream from Lewiston Dam, California, and change in constructed floodplain area from 1980 to 2011: $A$, cumulative area by study reach; $B$, cumulative change in area per year by study reach; $C$, area by study reach and river segments over time ....26

14. Graphs showing area of stable bars along the Trinity River downstream from Lewiston Dam, California, and change in stable bar area from 1980 to 2011: $A$, cumulative area by study reach; $B$, cumulative change in area per year by study reach; $C$, area by study reach and river segments over time 


\section{Figures-Continued}

15. Graphs showing area of the active channel along the Trinity River downstream from Lewiston Dam, California, and change in active channel area from 1980 to 2011: $A$, cumulative area by study reach; $B$, cumulative change in area per year by study reach; $C$, area by study reach and river segments over time.....

16. Graphs showing area of active bars along the Trinity River downstream from Lewiston Dam, California, and change in active bar area from 1980 to 2011: $A$, cumulative area by study reach; $B$, cumulative change in area per year by study reach; $C$, area by study reach and river segments over time.....

17. Graphs showing area of secondary water features along the Trinity River downstream from Lewiston Dam, California, and change in secondary water feature area from 1980 to 2011: $A$, cumulative area by study reach; $B$, cumulative change in area per year by study reach; $C$, area by study reach and river segments over time.

18. Graphs showing temporal changes in the active-channel from 1980 to 2011 for the Trinity River downstream from Lewiston Dam, California: $A$, baseflow shoreline length; $B$, active-channel width

19. Graphs showing streamflow measured at the Lewiston gage on the Trinity River, California, $1.5 \mathrm{~km}$ downstream from Lewiston Dam, from 1980 to 2011: $A$, mean daily and annual peak flows; $B$, annual average flows. ROD, Record of Decision.

20. Boxplots showing mean daily flows from 1980 to 2011 , grouped by month with minimum in-stream flow, for the Lewiston gage on the Trinity River, California: $A$, pre-ROD (Record of Decision) period; $B$, post-ROD period.

21. Graph showing contributing drainage area for 13 geomorphic reaches, delineated by vertical lines and described in table 2, along the Trinity River downstream from Lewiston Dam, California.

22. Graph showing the mean annual flow measured at five mainstem gages on the Trinity River, California, downstream of Lewiston Dam, California, from 1996 to 2011....35

23. Graphs showing mean daily flows measured at five mainstem gaging stations on the Trinity River, California, downstream from Lewiston Dam, from 1980 to 2011, and annual time series for four wettest years during the study period: $A, 1997 ; B, 1998$; $C, 2006 ; D, 2011$

24. Diagram showing summary of relevant management actions from 1976 to 2011 along the Trinity River downstream from Lewiston Dam, California.

25. Bar graph showing annual and cumulative volumes of sediment extraction and augmentation for Trinity River downstream from Lewiston Dam, California, from 1980 to 2011

26. Summary of constructed riparian and channel features along the Trinity River downstream from Lewiston Dam, California, in 1980, 1997, 2001, 2006, 2009, and 2011 .

27. Graphs showing changes in active-channel area due to bank erosion and accretion along the Trinity River downstream from Lewiston Dam, California, for five periods ending in 1997, 2001, 2006, 2009, and 2011

28. Graphs showing changes in active-bar area due to bar scour and accretion along the Trinity River downstream from Lewiston Dam, California, for five periods ending in 1997, 2001, 2006, 2009, and 2011

29. Graphs showing changes in bar vegetation along the Trinity River downstream from Lewiston Dam, California, for five periods ending in 1997, 2001, 2006, 2009, and 2011 ...43 


\section{Figures-Continued}

30. Graphs showing cumulative downstream change in the areal extent of exposed active bars and of the active channel along the Trinity River downstream from Lewiston Dam, California, for five periods ending in 1997, 2001, 2006, 2009, and 2011 ...45

31. Geomorphic feature maps for the Sven Olbertson Rehabilitation Site on the Trinity River, California, 1.0 floodplain kilometers downstream from Lewiston Dam, in 1980, 2001, and 2011

32. Geomorphic feature maps near Junction City on the Trinity River, California, 50.1 floodplain kilometers downstream from Lewiston Dam, in 1980, 2001, and 2011

33. Geomorphic feature maps for Conner Creek Rehabilitation Site on the Trinity River, California, 53.8 floodplain kilometers downstream from Lewiston Dam, in 1980, 2001, and 2011

34. Geomorphic feature maps at Lime Point on the Trinity River, California, 58.1 floodplain kilometers downstream from Lewiston Dam, in 1980, 2001, and 2011

\section{Tables}

1. Recommended flow releases to the Trinity River, California, from Lewiston Dam and associated management objectives.

2. Mapping protocol structure and geomorphic feature descriptions

3A. Geomorphic reach descriptions and restoration history for study segments along the Trinity River, California, downstream from Lewiston Dam: upper river segment......13

3B. Geomorphic reach descriptions and restoration history for study segments along the Trinity River, California, downstream from Lewiston Dam: central river segment....14

3C. Geomorphic reach descriptions and restoration history for study segments along the Trinity River, California, downstream from Lewiston Dam: lower river segment ......14

4. Uncertainty analysis for six geomorphic maps of the Trinity River, California, downstream from Lewiston Dam.

5. Summary of stream discharge data for the Trinity River, California, downstream from Lewiston Dam.

6. Summary of bar and bank changes during five study periods for the Trinity River, California, downstream from Lewiston Dam 


\section{Conversion Factors}

[Inch/pound to International System of Units]

\begin{tabular}{|c|c|c|}
\hline Multiply & By & To obtain \\
\hline \multicolumn{3}{|c|}{ Volume } \\
\hline acre-foot (acre-ft) & 1,233 & cubic meter $\left(\mathrm{m}^{3}\right)$ \\
\hline \multicolumn{3}{|c|}{ Flow rate } \\
\hline cubic foot per second $\left(\mathrm{ft}^{3} / \mathrm{s}\right)$ & 0.02832 & cubic meter per second $\left(\mathrm{m}^{3} / \mathrm{s}\right)$ \\
\hline \multicolumn{3}{|c|}{ [International System of Units to Inch/pound] } \\
\hline Multiply & By & To obtain \\
\hline \multicolumn{3}{|c|}{ Length } \\
\hline millimeter (mm) & 0.03937 & inch (in.) \\
\hline meter $(\mathrm{m})$ & 3.281 & foot (ft) \\
\hline kilometer (km) & 0.6214 & mile (mi) \\
\hline \multicolumn{3}{|c|}{ Area } \\
\hline square meter $\left(\mathrm{m}^{2}\right)$ & 10.76 & square foot $\left(\mathrm{ft}^{2}\right)$ \\
\hline square kilometer $\left(\mathrm{km}^{2}\right)$ & 0.3861 & square mile $\left(\mathrm{mi}^{2}\right)$ \\
\hline \multicolumn{3}{|c|}{ Volume } \\
\hline cubic meter (m3) & 264.2 & gallon (gal) \\
\hline \multicolumn{3}{|c|}{ Flow rate } \\
\hline cubic meter per year $\left(\mathrm{m}^{3} / \mathrm{yr}\right)$ & 0.000811 & acre-foot per year (acre-ft/yr) \\
\hline meter per year $(\mathrm{m} / \mathrm{yr})$ & 3.281 & foot per year (ft/yr) \\
\hline
\end{tabular}

\section{Datums}

Vertical coordinate information is referenced to the North American Vertical Datum of 1988 (NAVD 88).

Horizontal coordinate information is referenced to the North American Datum of 1983 (NAD 83).

Elevation, as used in this report, refers to distance above the vertical datum. 


\section{Abbreviations and Acronyms}

$\begin{array}{ll}\text { DTM } & \text { digital terrain model } \\ \text { EIS } & \text { Environmental Impact Statement } \\ \text { FPkm } & \text { floodplain kilometer } \\ \text { GIS } & \text { geographic information system } \\ \text { HVT } & \text { Hoopa Valley Tribe } \\ \text { RMSE } & \text { root mean square error } \\ \text { ROD } & \text { Record of Decision } \\ \text { TAF } & \text { thousand acre-feet } \\ \text { TRA } & \text { Trinity Restoration Associates, Inc. } \\ \text { TRD } & \text { Trinity River Division of the Central Valley Project } \\ \text { TRFE } & \text { Trinity River Flow Evaluation } \\ \text { TRRP } & \text { Trinity River Restoration Program } \\ \text { USFWS } & \text { U.S. Fish and Wildlife Service }\end{array}$

\section{Acknowledgements}

This study benefited from discussions with Bureau of Reclamation staff including Andreas Krause, Dave Gaeuman, and Eric Peterson and members of the Trinity River Restoration Program Physical Workgroup who provided helpful guidance and review.

Rose Wallick (U.S. Geological Survey, Portland, Oregon) and MacKenzie Keith (U.S. Geological Survey, Portland, Oregon) were instrumental in the development and analysis of the mapping geodatabase. 


\title{
Assessing Geomorphic Change along the Trinity River Downstream from Lewiston Dam, California, 1980 to 2011
}

\author{
By Jennifer A. Curtis, Scott A. Wright, J. Toby Minear, and Lorraine E. Flint
}

\section{Abstract}

The Trinity River Restoration Program, one of the nation's largest adaptively managed river restoration programs, requires periodic assessment to determine the effectiveness of management actions in restoring channel dynamics and habitat features. This study documents riparian and channel changes along an intensively managed 65-kilometer reach of the Trinity River in California, downstream from Lewiston Dam. The two primary periods of interest, from 1980 to 2001 and from 2001 to 2011, are separated by a shift in restoration activities mandated by the U.S. Department of the Interior December 2000 Record of Decision. The post-2001 restoration strategy increased managed-flow releases, gravel augmentation, watershed restoration, and mechanical channel rehabilitation.

We assessed the nature and extent of geomorphic change and a series of ecological performance measures (channel complexity, shoreline length, and channelfloodplain connectivity) by using a series of maps digitized from available rectified orthophotography acquired during low-flow conditions in 1980, 1997, 2001, 2006, 2009, and 2011. Lateral changes in riparian and channel features were used to quantify alluvial processes, and a review of existing streamflow, sediment, and restoration records was used to assess causal mechanisms. During the study period, natural bank erosion and mechanical rehabilitation of channel margins converted riparian features to channel features and expanded the active-channel area. The primary period of bank erosion and expansion of the active channel was from 1980 to 1997. Subsequent bar accretion from 1997 to 2001, followed by slightly greater bar scour from 2001 to 2006, took place primarily in the central and lower reaches of the study area, downstream of Indian Creek. In comparison, post-2006 bank and bar changes were spatially limited to reaches that had sufficient local transport capacity or sediment supply supported by gravel augmentation, mechanical channel rehabilitation, and tributary contributions.

The highest rates of change in the areal extents of channel and riparian features were observed during the pre-2001 period, which was longer and relatively wetter than the post-2001 period. A series of tributary floods in 1997, 1998, and 2006 increased channel complexity and floodplain connectivity. During the post-2006 period, managed-flow releases, in the absence of tributary flooding, combined with gravel augmentation and mechanical restoration, caused localized increases in sediment supply and transport capacity that led to smaller, but measurable, increases in channel complexity and floodplain connectivity in the upper river near Lewiston Dam. Extensive pre-2001 channel widening and the muted geomorphic response of channel rehabilitation sites to post-2001 managed flows highlight the need for continued monitoring and assessment of the magnitude, duration, and timing of prescriptive flows and associated geomorphic responses.

\section{Introduction}

In 1958, a plan was developed to increase water supplies and generate power for California's Central Valley Project, in part, by transferring water from the Trinity River (fig. 1) to the Sacramento River. The Trinity River Division (TRD) included construction of two main-stem dams. The reservoir behind Trinity Dam began filling in 1960, and Lewiston Dam was completed in 1963. Following closure of the Trinity Dam, annual water diversions commenced, and up to 75 to 90 percent of the upper Trinity River's annual streamflow, measured as inflow to Trinity Lake, was transferred to the upper Sacramento River (U.S. Fish and Wildlife Service and Hoopa Valley Tribe, 1999).

The combination of dam construction, flow diversion, and land-use practices (dredge mining and upland logging) caused channel aggradation, riparian encroachment, and simplification of channel morphology with concurrent reductions in channel complexity and channel-floodplain connectivity downstream from Lewiston Dam (Trinity River Taskforce, 1970).

Recognition that riparian and channel changes coincided with declines in salmon and steelhead populations led to an Environmental Impact Statement (EIS; U.S. Fish and Wildlife Service, 1980). The EIS determined the fisheries decline was primarily caused by streambed sedimentation, insufficient streamflow, and inadequate regulation of fish harvests. On the basis of these findings, channel bank rehabilitation and flow increases were recommended to restore salmon and steelhead populations (U.S. Fish and Wildlife Service, 1980). 


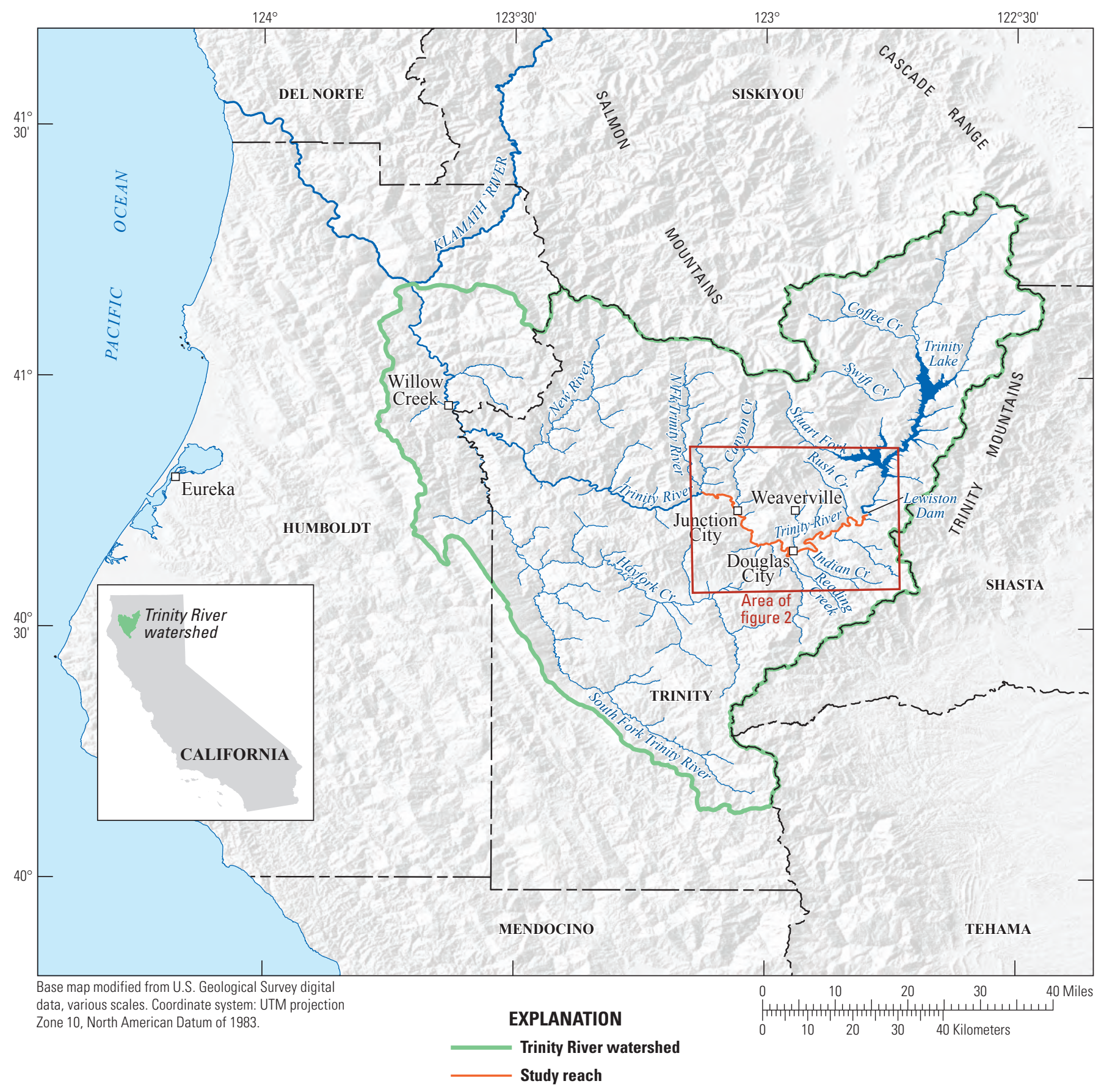

Figure 1. Study area, Trinity River, California. 
Although baseflow increases began in 1981, salmon and steelhead populations continued to decline, which led to additional environmental and experimental flow studies summarized in the Trinity River Flow Evaluation (TRFE; U.S. Fish and Wildlife Service and Hoopa Valley Tribe, 1999). The TRFE presented recommendations that were formally adopted in December 2000 by the U.S. Department of the Interior Record of Decision (ROD; U.S. Department of the Interior, 2000). The ROD explicitly required a restoration strategy that included managed-flow releases, gravel augmentation, mechanical channel rehabilitation, and watershed restoration. The Trinity River Restoration Program (TRRP), a multi-agency partnership, was tasked with overseeing implementation of mandated restoration and adaptive management. The TRRP's mission is to promote geomorphic processes responsible for creating and maintaining habitat sufficient to restore the salmonid fishery to pre-dam levels. Restoration of a dynamic alluvial channel, exhibiting all the characteristics of the pre-dam river, but at a smaller scale, is a primary goal.

\section{Purpose and Scope}

The purpose of this report is to provide results from a geomorphic assessment of the 65-kilometer $(\mathrm{km})$ restoration reach along the mainstem Trinity River, downstream from Lewiston Dam, completed by the USGS in cooperation with the TRRP. The study period began in 1980, prior to implementation of baseflow increases in 1981, and covered approximately two decades (1980 to 2001) prior to the ROD and one decade (2001 to 2011) following. The primary study objectives were as follows:

1. To develop a system-wide perspective of geomorphic features.

2. To determine the evolution of geomorphic features and the trajectories of geomorphic change.

3. To quantify ecologically significant measures of geomorphic change relevant to Trinity River fisheries restoration.

4. To evaluate the cumulative effects of natural and managed drivers of change.

We used six available rectified orthophotographs, acquired during baseflow conditions, to construct a series of retrospective geomorphic feature maps that are published in a companion report and geodatabase (Curtis and Guerrero, 2015; http://dx.doi.org/10.5066/F7TT4P04). The orthophotographs bracketed five study periods that included two pre-ROD periods (May 1980 to October 1997 and October 1997 to November 2001) and three post-ROD periods (November 2001 to July 2006, July 2006 to April 2009, and April 2009 to August 2011). Using the six geomorphic feature maps, we quantified spatial and temporal changes in riparian and channel features and assessed a series of ecological performance measures (channel complexity, shoreline length, and channel-floodplain connectivity) identified as primary metrics for understanding linkages between ecosystem benefits and restoration actions (Trinity River Restoration Program and ESSA Technologies Ltd., 2009).

During each of the five study periods, there were concurrent and sequential alterations in flow, sediment supply, and channel morphology. We interpreted cumulative change during each of the five periods in the context of controlling factors related to natural channel processes, flow and sediment management, and mechanical alterations of channel morphology. Results from this study are intended to help inform the design and implementation of future channel rehabilitation projects (Hoopa Valley Tribe and others, 2011a) and adaptive management of the TRRP restoration reach.

\section{Study Area}

The Trinity River traverses a region in the Central Klamath Mountain geologic province (Irwin, 1972, 1981) underlain by geologic terranes accreted to western North America during the late Mesozoic Era and early Tertiary Period (Ingersoll and Schweickert, 1986). A progression of eastward dipping thrust faults (Irwin, 1994) juxtaposes younger, Jurassic mixed-volcanic and sedimentary rocks against older, Devonian sedimentary rocks. During and subsequent to accretion, these geologic units were metamorphosed and intruded by igneous plutons, dikes, and sills. The Weaverville Formation, a Cenozoic gold-bearing fluvial deposit, was deposited on older stratigraphy (Diller, 1902) in the study area.

Anomalously high topography and surface exposure of Devonian rocks in the Klamath province indicate a period of geologically recent tectonic uplift. Inferred rapid uplift could be related to plate convergence at the nearby Cascadia subduction zone and Mendocino Triple Junction (Anderson, 2008). Inferred uplift rates also provide a tectonic mechanism for river incision and development of bedrock channels draining the central Klamath Mountains.

The Trinity River flows $270 \mathrm{~km}$ westward from its headwaters to its confluence with the Klamath River (fig. 1). The Trinity is the Klamath River's largest tributary and has a total drainage area of 7,670 square kilometers $\left(\mathrm{km}^{2}\right)$. Approximately one quarter of the Trinity River watershed $\left(1,850 \mathrm{~km}^{2}\right)$ is upstream from Lewiston Dam. The watershed is predominately mountainous and forested. Elevations range from 90 to 2,700 meters $(\mathrm{m})$ above sea level, and the highest elevations were glaciated during the Pleistocene. The channel network is primarily bedrock with intermittent alluvial reaches. Downstream of Lewiston Dam, the river flows southwest through a series of antecedent meanders superimposed across northwest-trending terranes. Near Douglas City, the river turns and flows northwest through a structurally controlled landscape. 
Assessing Geomorphic Change along the Trinity River Downstream from Lewiston Dam, California, 1980 to 2011

The climate in this region is Mediterranean, with hot, dry summers and cool, wet winters. Beginning in November, storm systems from the Pacific Ocean bring winter precipitation. Approximately 80 percent of the annual precipitation falls between November and March. The U.S. Forest Service has operated a weather station in Weaverville since 1905 (Weaverville RS, WVR, http:// www.cdec.water.ca.gov). The Weaverville station is at an elevation of $625 \mathrm{~m}$, where average annual precipitation is 935 millimeters $(\mathrm{mm})$, and average annual snowfall is 570 $\mathrm{mm}$. The maximum monthly precipitation, $530 \mathrm{~mm}$, fell in December 2005, and the maximum 24-hour precipitation, 140 $\mathrm{mm}$, fell on January 4, 1982. Elevations between 1,220 and $1,820 \mathrm{~m}$ are susceptible to rain-on-snow events (U.S. Fish and Wildlife Service and Hoopa Valley Tribe, 1999), which can produce large tributary floods.

The TRRP restoration reach extends from Lewiston Dam downstream to the confluence with the North Fork Trinity River (fig. 2). This $65-\mathrm{km}$ river segment along the mainstem Trinity River was identified as the most severely affected by flow regulation and diversion and was recommended for restoration by the initial flow evaluation (U.S. Fish and Wildlife Service, 1994). The study reach is a partially confined gravel-bed river that has a nearly constant slope of 0.002 meters per meter (fig. 3). The nearly constant slope indicates that bedrock functions as a primary control of channel slope. This assertion is further supported by intermittent bedrock exposures in the active channel throughout the study reach. The channel pattern is primarily singlethread, and the dominant channel type is pool-riffle with intermittent plane-bed and canyon reaches (Montgomery and Buffington, 1998).

From the early 1860 s to the early 1900 s, large-scale hydraulic mining of the gold-bearing Weaverville Formation and, to a lesser extent, logging increased sediment supplies to the study reach. Deposition of large-diameter mining sediment aggraded the channel and valley bottom by several feet (Trinity River Taskforce, 1970; Krause and others, 2010). Beginning in the late 1800s and continuing until 1960, dredge mining of the mainstem channel overturned more than 70 percent of the floodplain area (Stearns, 1969), depositing large piles of coarse tailings (gravel, cobble, and boulder) up to $12 \mathrm{~m}$ high that confine the modern river in some locations (Krause, 2012b). Many of these tailings piles were reworked by the 1955 and 1964 floods (Ritter, 1968), producing an extensive set of historic terraces and inset floodplains. Redistribution of stored mining sediment and tributary confluence aggradation during the 1964 flood led to the first mechanical restoration effort in 1965 that involved confluence channelization. Notably, smaller scale hydraulic mining continued in the study reach until 1970.

\section{In-Stream Effects of the Trinity River Diversion}

In-stream effects related to Trinity River flow diversions are documented explicitly in the TRFE (U.S. Fish and Wildlife Service and Hoopa Valley Tribe, 1999) and numerous project reports. In this report, we review the evolution of flow and sediment management strategies to support a thorough understanding of the study reach history. Note that we use English units, cubic feet per second $\left(\mathrm{ft}^{3} / \mathrm{s}\right)$ and thousand acre-feet (TAF), to characterize flow data because they are commonly used by the Trinity River management community.

The influence of flow regulation and diversion on streamflow variability is readily apparent in mean daily flows recorded at the Lewiston gaging station (fig. 4; Trinity River at Lewiston, USGS station identification number 11525500), $1.5 \mathrm{~km}$ downstream from Lewiston Dam (fig. 2). The predam flow regime included summer base flows, winter-storm peaks, and spring-snowmelt peaks, which created variable seasonal flow conditions. Post-dam flow variability decreased and flow releases from 1964 to 1973 were pursuant to the 1955 Congressional Act, which authorized construction and operation of the TRD by the Bureau of Reclamation. The TRD maintained daily flows between 150 and $250 \mathrm{ft}^{3} / \mathrm{s}$ at the Lewiston gage, and the annual flow-release volume was set at 120.5 TAF, with periodic, larger safety-of-dam releases.

Post-dam salmonid habitat deterioration and population declines (Trinity River Taskforce, 1970) prompted a request in 1980 by the California Department of Fish and Game to increase the annual flow release from Lewiston Dam to the Trinity River to 315 TAF. Subsequent investigations of the relation between in-stream flows and salmonid habitat by the U.S. Fish and Wildlife Service (USFWS) were incorporated into an EIS (U.S. Fish and Wildlife Service, 1980), which concluded that insufficient streamflow was the most critical limiting factor for restoring salmonid populations. The EIS explicitly recommended channel rehabilitation by mechanical restoration and increases in minimum annual flow volumes to $140 \mathrm{TAF}$ in critically dry water years, $220 \mathrm{TAF}$ in dry water years, and $340 \mathrm{TAF}$ in normal or wet water years.

In 1981, a Department of the Interior Secretarial Decision was issued that mandated baseflow increases and completion of a flow evaluation study to evaluate the potential effects of implementing prescriptive in-stream flows to mimic variable climatic conditions and provide suitable flows to restore dynamic fluvial processes, maintain channel complexity, and support all stages of the salmonid life cycle. Drier climatic conditions prevailed from 1986 to 1990, which delayed flow increases. In the early $1990 \mathrm{~s}$, a series of 3,000 to $6,000 \mathrm{ft}^{3} / \mathrm{s}$ experimental flows were released, and in-stream effects were monitored as part of an environmental assessment (EA). 


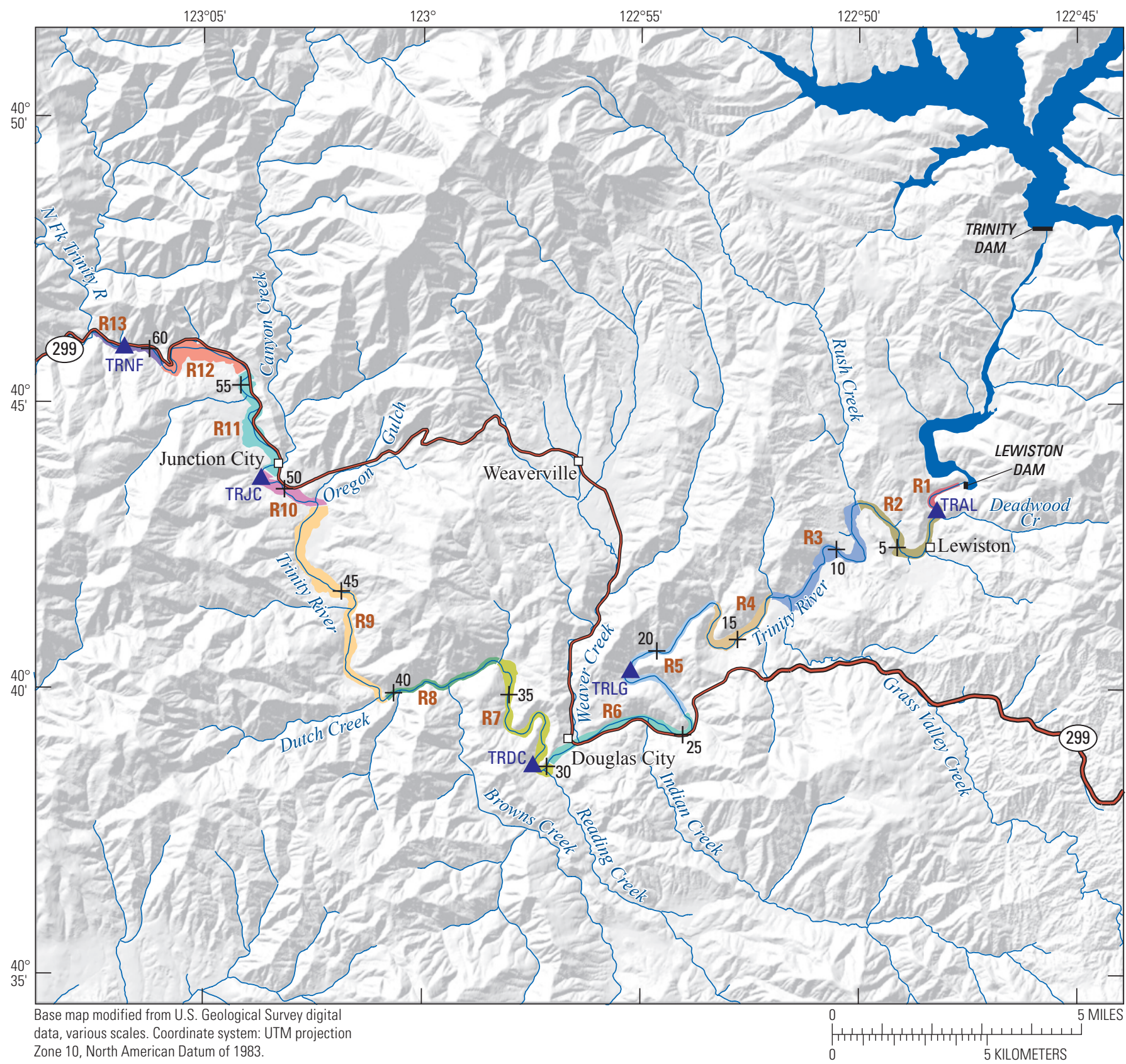

EXPLANATION

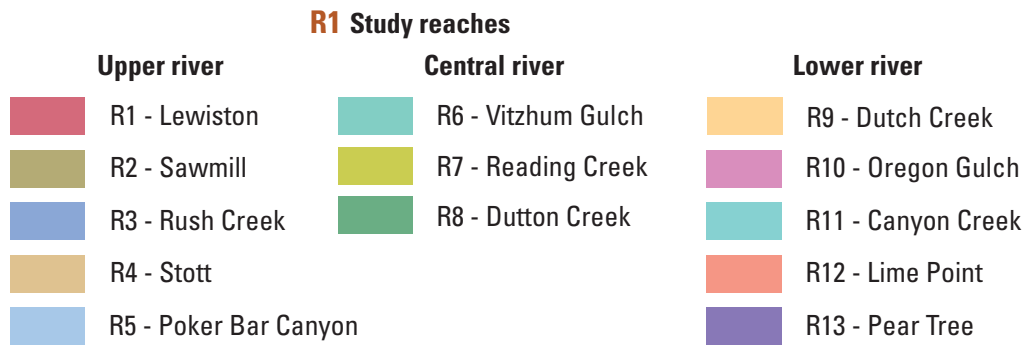

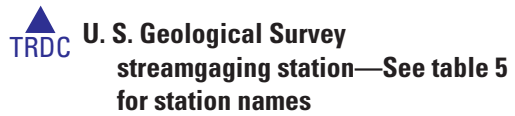

+5 Floodplain kilometer-distance downstream from Lewiston Dam

Figure 2. Trinity River restoration reach, in California, from Lewiston Dam downstream to the North Fork Trinity confluence and 13 geomorphic reaches, within 3 river-channel segments, used as the spatial framework for interpretation of mapping results. 


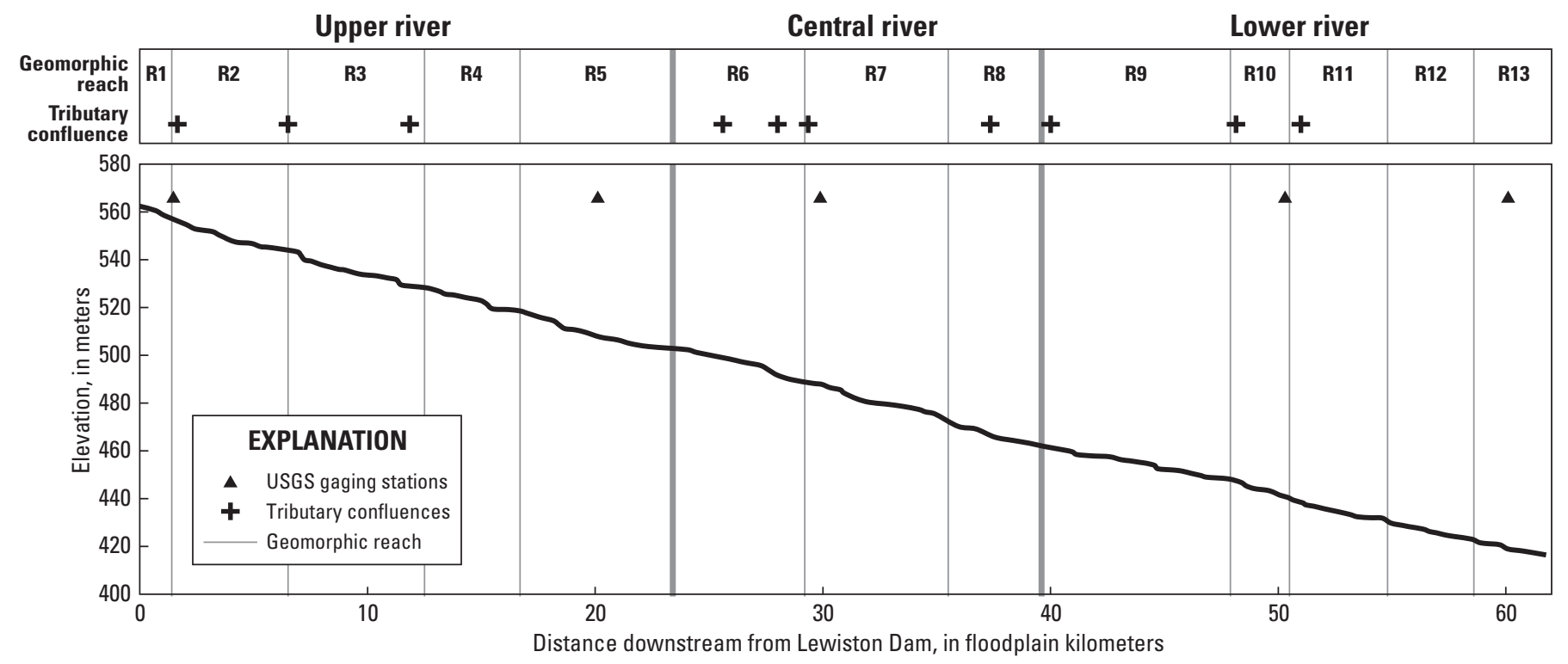

Figure 3. Elevation profile of the Trinity River restoration reach, California, estimated from 10-meter-resolution digital elevation data. See table 3 for description of the 13 geomorphic reaches.

The TRFE was completed in 1999, and flow recommendations were formally adopted in the ROD (U.S. Department of the Interior, 2000), but litigation delayed full implementation of the ROD flows until December 2005. Post-ROD flow management included large increases in annual flow volumes compared to those initially recommended in the 1980 EIS. In critically dry water years, the EIS recommendation of 140 TAF was more than doubled to 369 TAF. The EIS recommendation of 340 TAF was increased to 647 TAF during normal years and to 701 TAF during wet years (table 1).

An important change in post-ROD flow management was the implementation of an annual spring-flow release with specific geomorphic objectives (table 1). The annual peak release typically begins in early May and can extend into mid-July depending on the water-year type. Water-year type and the spring-flow release are determined in April of each year on the basis of forecasted annual-flow volumes at the Lewiston stream gage (Krause, 2012a). The peak release can be described as a "benched" hydrograph, with rapid increases in the rising limb, and a gradual decrease in the falling limb that is punctuated by periods of steady flows referred to as "benches" (U.S. Fish and Wildlife Service and Hoopa Valley Tribe, 1999). The "benches" are designed to support bed mobility, scour, and geomorphic objectives listed in table 1.

A post-dam sediment deficit existed downstream of Lewiston Dam (Gaeuman and Krause, 2011). Sediment deficit conditions occur when transport capacity exceeds sediment supply, which often results in scour and evacuation of bedmaterial to downstream reaches (Schmidt and Wilcock, 2008; Draut and others, 2011). Excess transport capacity immediately downstream from dams, typical for reaches that lack sufficient sediment supply, can lead to coarsening of the channel bed, decreased bed mobility, and channel incision. Within the study reach, changes in the substrate grain size relative to pre-dam conditions are unknown, but gaging measurements, collected at a cableway $2.5 \mathrm{~km}$ downstream from Lewiston Dam, indicated negligible post-dam channel incision (Gaeuman, 2008).

Abundant tributary and in-channel sediment sources exist in downstream study reaches (Graham Matthews and Associates, 2001), where sediment deficit conditions transition to equilibrium or surplus conditions (Gaeuman and Krause, 2011). The transition from deficit to surplus conditions often occurs downstream from the first major tributary confluence (Schmidt and Wilcock, 2008) or in pre-dam aggradation zones, where modern bed and bank processes recruit stored sediment from in-channel or floodplain sources (Draut and others, 2011). Beginning at about $3 \mathrm{~km}$ downstream from Lewiston Dam, large amounts of legacy mine tailings are stored along channel margins, but flows in this reach are insufficient to scour and transport this large-diameter material. Prior to construction of sediment-retention ponds in 1986, Grass Valley Creek (11.9 floodplain kilometers, or FPkm) was the first large contributor of sediment downstream from Lewiston Dam (Graham Matthews and Associates, 2001). At the time of writing this report, almost all bed-material sized sediment from Grass Valley Creek is trapped in a series of retention ponds constructed at the confluence in 1986. After 1986, Indian Creek (25.6 FPkm) functioned as the first important contributor of sediment downstream from Lewiston Dam (Graham Matthews and Associates, 2001). 


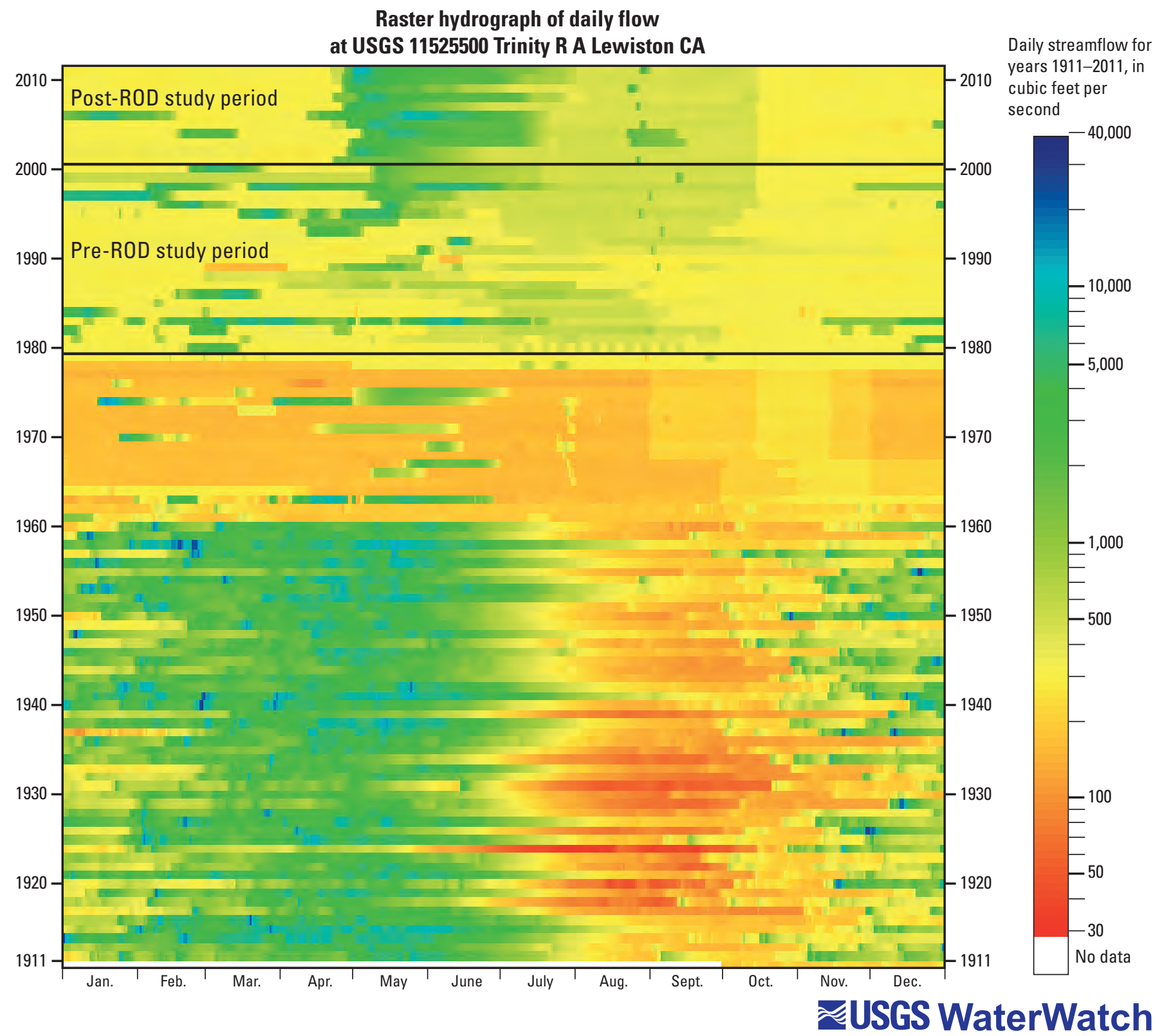

Figure 4. Raster hydrograph (http://waterwatch.usgs.gov/index.php?id=wwchart_rastergraph) showing mean daily flows measured 1.5 kilometers downstream from Lewiston Dam (fig. 2) along the Trinity River, California. Hydrograph shows monthly and annual variability of mean daily flows for 1911 to 2011. Pre- and post-ROD study periods are separated by the U.S. Department of the Interior Record of Decision (U.S. Department of the Interior, 2000). ROD, Record of Decision. 
Table 1. Recommended flow releases to the Trinity River, California, from Lewiston Dam and associated management objectives.

[See report by Hoopa Valley Tribe and others (2011b) for additional details; acre-ft, acre-foot; D84, particle diameter that represents 84 percent of the grain-size distribution of channel bed sediment; days/yr, days per year; $\mathrm{ft}^{3} / \mathrm{s}$, cubic feet per second; ROD, record of decision; yr, year]

\begin{tabular}{|c|c|c|c|c|c|c|c|}
\hline $\begin{array}{l}\text { Water-year } \\
\text { type }\end{array}$ & $\begin{array}{l}\text { Frequency of } \\
\text { water-year } \\
\text { type during } \\
\text { post-ROD } \\
\text { period } \\
\text { (percent) }\end{array}$ & $\begin{array}{l}\text { Recom- } \\
\text { mended } \\
\text { annual flow } \\
\text { released to } \\
\text { Trinity River } \\
\text { (acre-ft) }\end{array}$ & $\begin{array}{l}\text { Recom- } \\
\text { mended } \\
\text { peak } \\
\text { release at } \\
\text { Lewiston } \\
\left(\mathrm{ft}^{3} / \mathrm{s}\right)\end{array}$ & $\begin{array}{l}\text { Recom- } \\
\text { mended } \\
\text { duration of } \\
\text { peak release } \\
\text { (days) }\end{array}$ & $\begin{array}{c}\text { Pre-ROD } \\
\text { exceedence } \\
\text { of recom- } \\
\text { mended } \\
\text { peak flow } \\
\text { (days/yr) }\end{array}$ & $\begin{array}{l}\text { Post-ROD } \\
\text { exceedence } \\
\text { of recom- } \\
\text { mended } \\
\text { peak flow } \\
\text { (days/yr) }\end{array}$ & Objectives \\
\hline Critically dry & 12 & 369,000 & 1,500 & 36 & 31 & 118 & $\begin{array}{l}\text { Discourage encroachment of riparian } \\
\text { vegetation on low bars. }\end{array}$ \\
\hline Normal & 20 & 647,000 & 6,000 & 5 & 5 & 8 & $\begin{array}{l}\text { Channel-bed surface mobilization on } \\
\text { bars and riffles. Coarse-sediment } \\
\text { transport equal to sediment supply. } \\
\text { Tributary confluence maintenance. } \\
\text { Channel migration. Managed floodplain } \\
\text { inundation and fine-sediment deposition. } \\
\text { Scour of 0-1 year old riparian seedlings } \\
\text { on lower bar surfaces. Recharge of } \\
\text { shallow groundwater table. All effects } \\
\text { realized at lower flows. }\end{array}$ \\
\hline Wet & 28 & 701,000 & 8,500 & 5 & 0.1 & 1.7 & $\begin{array}{l}\text { Scour of bar margins greater than or } \\
\text { equal to D84 depth. Coarse sediment } \\
\text { movement. Scour of } 1-2 \text { year old } \\
\text { riparian seedlings and lower bar surfaces. } \\
\text { All effects realized at lower flows. }\end{array}$ \\
\hline $\begin{array}{l}\text { Extremely } \\
\text { wet }\end{array}$ & 12 & 815,000 & 11,000 & 5 & 0 & 0.5 & $\begin{array}{l}\text { Scour depth of alternate bars greater than } \\
\text { two times D84. Managed floodplain } \\
\text { scour. Side-channel maintenance. Scour } \\
\text { of } 2-3 \text { year old riparian seedlings and } \\
\text { lower bar surfaces. All effects realized at } \\
\text { lower flows. }\end{array}$ \\
\hline
\end{tabular}

Decreases in post-dam flows resulted in aggradation of tributary confluences (Ritter, 1968) and accumulation of undesirable fine bed material primarily downstream of Grass Valley Creek (U.S. Fish and Wildlife Service and Hoopa Valley Tribe, 1999). The TRFE suggested that post-dam decreases in coarse bed material reduced successful salmonid spawning and simplified the structure of available physical habitat (U.S. Fish and Wildlife Service and Hoopa Valley Tribe, 1999). There was concern that the relatively large annual flow releases necessary to mobilize and scour undesirable fine bed material would result in the transport and removal of existing gravel in the reach immediately downstream from Lewiston Dam, which, despite effects related to flow regulation and diversion, continued to function as a primary spawning reach for regional salmonid production (U.S. Fish and Wildlife Service, 1989). To mitigate transport of gravel out of the primary spawning reach, the ROD mandated gravel augmentation in the upper river.
Gravel augmentation in the reach immediately downstream from Lewiston Dam began in 1998 with in-channel placement of coarse-sized bed material. Note that the TRRP defines coarse bed material as all particles greater than $8 \mathrm{~mm}$ in diameter (Gaeuman and Krause, 2011). Recently, Gaeuman (2008) determined an optimal particlesize distribution (9.5 to $125 \mathrm{~mm})$ and annual quantity $(5,400$ cubic meters, or $\mathrm{m}^{3}$ ) for long-term maintenance of coarse bed material in the upper river.

\section{Methods}

The objectives of this study were to develop a system-wide perspective of geomorphic features and to assess cumulative geomorphic change and controlling factors during five periods spanning 1980 to 2011. We characterized the spatial distribution of geomorphic features along the study 
reach by using a series of retrospective geomorphic maps and completed geospatial analysis to assess cumulative change during each period. Geomorphic changes were interpreted in the context of controlling factors related to natural processes, flow and sediment management, and mechanical restoration.

\section{Estimating Geomorphic Change}

Geomorphic maps published in a companion report and geodatabase (Curtis and Guerrero, 2015; http://dx.doi. org/10.5066/F7TT4P04) were used to classify upland, riparian, and channel features. The map dates bracket relevant geomorphic events and include three dates that span the preROD period (May 16, 1980; October 20, 1997; November 7, 2001) and three dates that span the post-ROD period (July 25, 2006; April 16, 2009; August 16, 2011). The orthophotographs used as base maps were acquired during baseflow conditions, about $300 \mathrm{ft}^{3} / \mathrm{s}$, when channel features were well exposed.

A map boundary was defined on the basis of the area inundated by a 500 -year recurrence interval flood. This boundary, constructed by a one-dimensional flow model (California Department of Water Resources, 2007), roughly defined the valley bottom. The boundary was extended by $30 \mathrm{~m}$ to include all features of interest. Geomorphic features larger than $30 \mathrm{~m}^{2}$ within the map boundary were digitized at a scale of 1:1,000. Mapping was limited to exposed features because subaqueous features, although evident in some years, could not be consistently digitized.

The hierarchy of the mapping protocol included upland, riparian, and channel features similar to recent studies on the Colorado River and its main tributary, the Green River (Schmidt and others, 1999; Grams and Schmidt, 2002). The protocol was designed to assess spatial and temporal changes in geomorphic features and ecologically important measures of geomorphic change relevant to restoration of Trinity River fisheries. Previous studies determined that the linkage between habitat and channel geomorphology was represented best by channel complexity, channel-floodplain connectivity, and shoreline length, which represent fundamental variables governing the quality and quantity of available salmonid habitat (U.S. Fish and Wildlife Service and Hoopa Valley Tribe, 1999; Trinity River Restoration Program and ESSA Technologies Ltd., 2009). The mapping protocol, geomorphic feature definition, and the ArcGIS (v. 10.0) geodatabase structure are explained in table 2.

Geomorphic features were delineated by orthophoto interpretation, and specific observational criteria are described in table 2. The mapping was further constrained by a contour map derived from a 2009 digital terrain model (DTM, Woolpert, 2010) and a series of water-surface extents constructed by a one-dimensional flow model. The mapping was field checked in the summer of 2012. Observational criteria used to classify geomorphic features included the age, density, and type of vegetation; spatial transitions among vegetation types; evidence of scour or deposition; and presence of stagnant or flowing water. Although features were primarily delineated on the basis of these criteria, the 2009 contour map helped delineate relatively static features, and modeled water surfaces were used to assess riparian inundation extents and to interpret channel-floodplain connectivity. Water-surface extents were constructed on the basis of flow releases from Lewiston Dam, which ranged from 2,000 to $11,000 \mathrm{ft}^{3} / \mathrm{s}$ with tributary flows incorporated downstream. Lower elevation channel features were topographically inset relative to riparian and upland features. This nested topographic relation is illustrated in figure 5. Generally, higher elevation features are older and inundated less frequently by larger flows.

The boundary between the upland and riparian environments is delineated by the pre-dam floodplain, which is a relict depositional landform that is partially inundated at $6,000 \mathrm{ft}^{3} / \mathrm{s}$ and fully inundated at about $11,000 \mathrm{ft}^{3} / \mathrm{s}$. Under the regulated-flow regime in use at the time of writing, the upland environment is inundated only during extreme flows that have large tributary contributions.

Three floodplain types were defined: a relatively continuous, higher elevation pre-dam floodplain; a series of intermittent constructed floodplains; and lower elevation topographic benches created by the post-ROD flow regime. Isolated constructed floodplains were created by mechanical rehabilitation (vegetation removal, re-contouring, and surface lowering) as part of the USFWS bank-rehabilitation program in the early 1990s and by the TRRP after 2005 . The larger scale TRRP projects included constructed floodplains designed to be inundated by the post-ROD mean annual peak-flow release (about $6,000 \mathrm{ft}^{3} / \mathrm{s}$ ). The lowest elevation riparian features are post-dam topographic benches composed of coalesced bars. The post-dam benches are composed of previously active bars that were stabilized by 1975 as a result of declines in transport capacity due to flow regulation and concurrent vegetation encroachment. By 1980, these stable bars had coalesced into relatively continuous low-elevation floodplain features. Under the flow regime in use at the time of writing, these benches are inundated by flows ranging between about 2,000 and 4,500 ft $3 / \mathrm{s}$. Portions of these features are elevated as a result of vegetation encroachment, which facilitated sediment deposition and development of riparian berms. The extent and frequency of inundation is influenced by the presence of these berms, which act as natural levees.

The active-channel environment (table 2) includes the baseflow-wetted channel and morphologically activechannel margins characterized by bedload transport. Similar to previous studies (Grant and Swanson, 1995; Church, 2002; Zilliani and Surian, 2012), we delineated a dynamic active-channel boundary that included wetted-channel features and unvegetated or sparsely vegetated bars. The mapping protocol accommodated the transitional boundary between the channel and riparian environments that expands and contracts through time. 


\section{Assessing Geomorphic Change along the Trinity River Downstream from Lewiston Dam, California, 1980 to 2011}

Table 2. Mapping protocol structure and geomorphic feature descriptions.

[See companion report by Curtis and Guerrero (2015) for additional details. Abbreviations: FPkm, floodplain kilometer; $\mathrm{ft}^{3} / \mathrm{s}$, cubic foot per second; $\mathrm{km}$, kilometer; $\mathrm{km}^{2}$, square kilometer; m, meters; ROD, record of decision; TRRP, Trinity River Restoration Program; USFWS, U.S. Fish and Wildlife Service; $\%$, percent]

\begin{tabular}{|c|c|}
\hline Geomorphic setting & Feature description \\
\hline \multicolumn{2}{|l|}{ Terrestrial environment } \\
\hline Uplands & $\begin{array}{l}\text { Uplands include areas underlain by soil, colluvium, alluvium, bedrock, or legacy mine tailings. Unless } \\
\text { altered by mechanical restoration, the areal extent of upland features typically persists throughout the } \\
\text { historic imagery. }\end{array}$ \\
\hline \multicolumn{2}{|l|}{ Riparian environment } \\
\hline Islands & $\begin{array}{l}\text { Alluvial features bounded on all sides by water and distinguished from medial bars by denser mature } \\
\text { vegetation, greater areal extents, and higher elevations. Although islands existed prior to 1980, most } \\
\text { were created by side-channel construction. }\end{array}$ \\
\hline Floodplains & $\begin{array}{l}\text { Floodplain features typically exhibit a vegetation gradient with the highest density of vegetation along the } \\
\text { active-channel margin; density decreases with increasing distance from the channel margin. }\end{array}$ \\
\hline Pre-dam floodplain & $\begin{array}{l}\text { This broad, relict depositional feature was created and inundated annually by the unregulated pre-dam flow } \\
\text { regime, but is inundated periodically under the post-dam flow regime by flows between about } 6,000 \text { and } \\
11,000 \mathrm{ft}^{3} / \mathrm{s} \text {. }\end{array}$ \\
\hline $\begin{array}{l}\text { Post-dam topographic } \\
\text { bench }\end{array}$ & $\begin{array}{l}\text { Depositional features composed of coalesced bars stabilized prior to } 1975 \text { because of declines in scouring } \\
\text { flows and the associated encroachment of vegetation. Portions of these features are elevated because of } \\
\text { vegetation-facilitated sediment deposition and development of a riparian berm along the channel margin. }\end{array}$ \\
\hline Riparian wetlands & $\begin{array}{l}\text { These disconnected aquatic features are outside the modern active-channel boundary. Only areas containing } \\
\text { water in the base imagery were mapped, even when it was apparent that additional areas would be } \\
\text { inundated seasonally. }\end{array}$ \\
\hline Other & Unique constructed features, such as borrow pits and gravel-recruitment piles. \\
\hline \multicolumn{2}{|l|}{ Active-channel environment } \\
\hline Baseflow wetted channel & $\begin{array}{l}\text { The primary channel delivers the majority of flow and, where the channel splits, it is identified as the } \\
\text { widest channel. Wetted-channel area is delineated by the wetted perimeter, as seen in the base imagery. }\end{array}$ \\
\hline Alcove & $\begin{array}{l}\text { Secondary water feature connected at one end to any wetted channel, including mainstem, tributary, side- } \\
\text { channel, or split-flow channel. }\end{array}$ \\
\hline Wetland & Secondary water feature completely disconnected from any other wetted-channel feature. \\
\hline Side-channel & $\begin{array}{l}\text { Secondary channels connected to the primary channel at the upstream and downstream ends and } \\
\text { distinguished from split-flow channels by conveyance of less than } 20 \% \text { of total summer baseflow and } \\
\text { generally less than } 10 \% \text {. The percentage of flow conveyance was estimated from channel widths. }\end{array}$ \\
\hline Split-flow channel & $\begin{array}{l}\text { Secondary channels created by flow separation that results in a change in the river morphology. Split-flow } \\
\text { channels convey between } 20 \text { and } 50 \% \text { of baseflow. The percentage of flow conveyance was estimated } \\
\text { from channel widths. }\end{array}$ \\
\hline Bar & $\begin{array}{l}\text { Dynamic features created by bedload transport typically oriented parallel to the primary flow direction. The } \\
\text { boundary between bars and adjacent riparian or upland features was delineated by using observational } \\
\text { criteria that included morphology, vegetation type and density, and physical evidence of scour or } \\
\text { deposition. }\end{array}$ \\
\hline Lateral & $\begin{array}{l}\text { Depositional channel feature created and maintained by active bedload transport and attached to the } \\
\text { channel margin. }\end{array}$ \\
\hline Medial & $\begin{array}{l}\text { Depositional channel feature created and maintained by active bedload transport and surrounded by water } \\
\text { on all sides. }\end{array}$ \\
\hline
\end{tabular}


Table 2. Mapping protocol structure and geomorphic feature descriptions.-Continued

[See companion report by Curtis and Guerrero (2015) for additional details. Abbreviations: FPkm, floodplain kilometer; $\mathrm{ft}^{3} / \mathrm{s}$, cubic foot per second; $\mathrm{km}$, kilometer; km², square kilometer; m, meters; ROD, record of decision; TRRP, Trinity River Restoration Program; USFWS, U.S. Fish and Wildlife Service; $\%$, percent]

\begin{tabular}{|c|c|}
\hline Geomorphic setting & Feature description \\
\hline \multicolumn{2}{|c|}{ Active-channel environment-Continued } \\
\hline Bedrock outcrops & $\begin{array}{l}\text { Static, non-alluvial features persistent in most or all years of base imagery. Can be buried by sediment in } \\
\text { some years and exposed in others. Bedrock outcrops are typically darker than alluvial features and have } \\
\text { a rough tone, jagged boundary, and lineations indicative of bedrock texture. }\end{array}$ \\
\hline Other & $\begin{array}{l}\text { Unique constructed features, such as hydraulic grade controls, bank stabilization features, and historic } \\
\text { bridge pilings. }\end{array}$ \\
\hline \multicolumn{2}{|l|}{ Vegetation density } \\
\hline Bare to sparse & Vegetation covers less than $10 \%$. \\
\hline Moderate & Vegetation covers 10 to $40 \%$. \\
\hline Dense & Vegetation covers greater than $40 \%$. \\
\hline Stable & $\begin{array}{l}\text { No physical evidence of scour, mobilization, or deposition in the current imagery when compared to the } \\
\text { previous imagery. The channel margin can have bare to dense vegetation, but must have a stable areal } \\
\text { extent. }\end{array}$ \\
\hline Active & $\begin{array}{l}\text { Obvious physical evidence of scour, mobilization, or incipient deposition when compared to previous } \\
\text { imagery. The baseflow-channel margin and the bar-surface area must be bare to sparsely vegetated in the } \\
\text { current imagery. }\end{array}$ \\
\hline
\end{tabular}

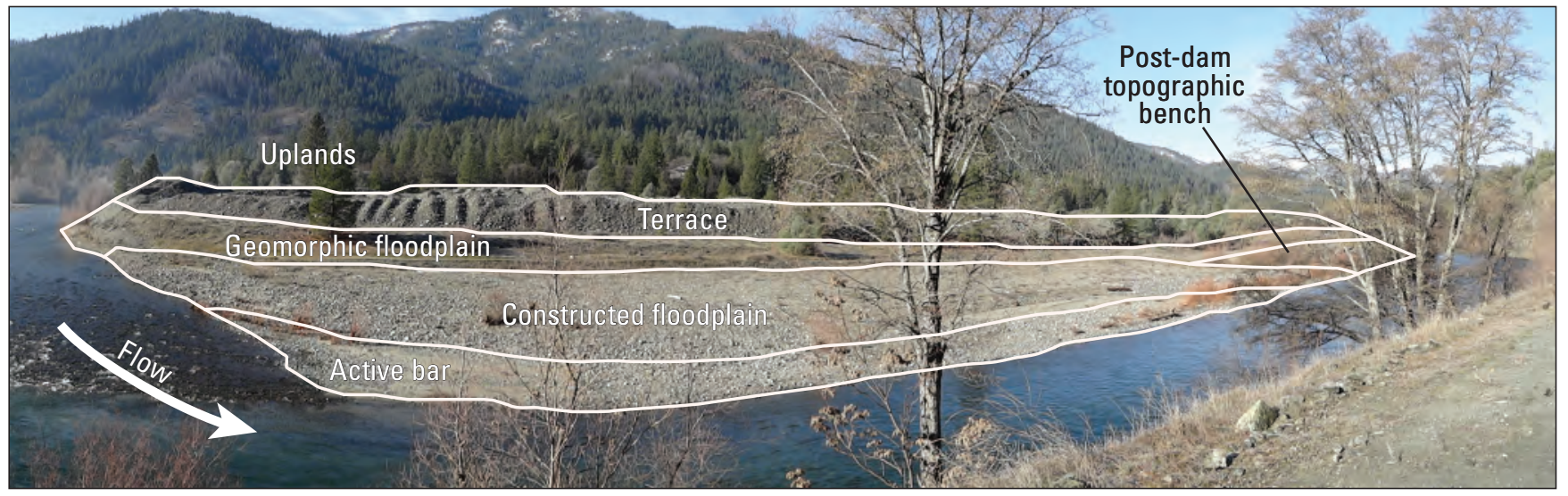

Figure 5. Example of the topographic relations among depositional and constructed features for the Trinity River downstream from Lewiston Dam, California (photograph by J.A. Curtis). Photo shows left bank downstream of Canyon Creek (51 floodplain kilometers, or FPkm). 


\section{Assessing Geomorphic Change along the Trinity River Downstream from Lewiston Dam, California, 1980 to 2011}

Channel features were assigned either to mainstem or tributary environments, and a simple bar classification (medial and lateral) was used (table 2). The presence of flowing or stagnant water delineated the wetted perimeter of baseflow channels and secondary water features (split-flow channels, side channels, alcoves, and aquatic wetlands). For the baseflow channels and secondary water features, only areas containing water were digitized, even when it was apparent that additional areas were inundated at higher flows. Three additional feature attributes were included in the geodatabase: restoration, vegetation density, and bar stability. Constructed features were labeled, which enabled assessment of features created or altered mechanically by in-channel gravel placement, side-channel construction, or bank rehabilitation. Vegetation density was estimated for all bar features, and bar stability was defined by vegetation density estimates, evidence of scour or deposition, and the presence or absence of vegetation along the baseflow-channel margin. Active bars typically have bare-to-sparse vegetation and a dynamic perimeter along the channel margin. In comparison, stable bars can have bare-to-dense vegetation, but more typically are characterized by moderate-to-dense vegetation and generally have a stable areal extent in consecutive orthophotographs.

\section{Interpretation of Geomorphic Mapping}

A spatial framework for interpreting results was developed on the basis of longitudinal changes in transport capacity and sediment-supply conditions. The framework was inferred from valley and channel confinement, location of tributary confluences, and the presence of in-channel legacy mine tailings and was used to delineate study reaches. The mainstem was initially divided into upper, central, and lower channel segments and then was subdivided into 13 geomorphic reaches (table 3). Lateral changes in channel and riparian features caused by bar and bank processes were investigated at a 1-km sub-reach scale.

Similar to recent studies by Wallick and others (2010, 2011), floodplain distance, rather than channel distance, was used to reference study-reach locations because distances along this line were static during the study period, whereas channel distances varied with time. Floodplain distance was defined as the distance downstream from Lewiston Dam along a centerline digitized within the pre-dam floodplain boundary. The numbering system begins at Lewiston Dam and ends upstream from the North Fork Trinity River confluence.

Channel lengths were estimated by using channel centerlines, digitized within the baseflow channel boundary for each of the six orthophotographs. Reach-averaged estimates of active-channel widths were calculated by dividing the active-channel area by channel length. The active-channel area included the primary wetted channel; secondary water features; in-channel features, such as bedrock outcrops; and active bars.
Two channel attributes that characterize the quality and quantity of available habitat are channel complexity and shoreline length (Trinity River Restoration Program and ESSA Technologies Ltd., 2009). Channel complexity was estimated by summing the areal extents of active bar and secondary water features. The perimeter of the wetted channel edge, including the primary baseflow channel and all connected secondary water features, was used to estimate the shoreline length.

We created five change maps, which preserved individual map attributes and bracketed the period of interest, by intersecting consecutive maps. Change polygons, which represent the nature and extent of bar and bank processes, were created and summarized for each of the $1-\mathrm{km}$ subreaches by using a series of conditional statements. Bar-accretion polygons were identified by the conversion of a water feature to a bar feature, and bar-scour polygons were identified by the conversion of a bar to water feature. Bank-erosion polygons were identified by the conversion of an upland or riparian feature to a channel feature, and bank-accretion polygons were identified by the conversion of a channel feature to a riparian feature. We also investigated bar-vegetation dynamics by using conditional statements to quantify the area converted from a sparsely vegetated to a densely vegetated bar, indicative of stabilization by vegetation encroachment, and the area converted from a densely vegetated to sparsely vegetated bar, indicative of scour and mobilization.

\section{Uncertainty and Error Analysis}

Uncertainty and error result when real world data are transferred to digital formats (Mount and Louis, 2005; Hughes and others, 2006). Errors associated with digitized data include operational errors, discharge differences during photo acquisition, and digitizing errors due to features obscured by vegetation or shadows (table 4). Curtis and Guerrero (2015) determined that operational and variable discharge errors were negligible, and digitizing errors based on the accuracy and precision of the digitizing process were conservatively inferred to be about 10 percent.

In this report, we present an additional error analysis associated with interpreting lateral channel changes. Although the root mean square error (RMSE) is generally regarded as a poor indicator of overall horizontal accuracy (Hughes and others, 2006), it is typically the only metric available to define uncertainty associated with lateral channel changes quantified by using repeat rectified photography (O'Connor and others, 2003; Micheli and others, 2004; Draut and others, 2008; Wallick and others, 2010; Wallick and others, 2011).

The greatest RMSE among the orthophotos was used to determine a threshold polygon area to address the horizontal uncertainty due to poor alignment. Change polygons smaller than the threshold area likely represent rectification errors and were removed from the lateral change analyses. The 1980 imagery had the greatest estimated RMSE (9.8 m; table 4). 


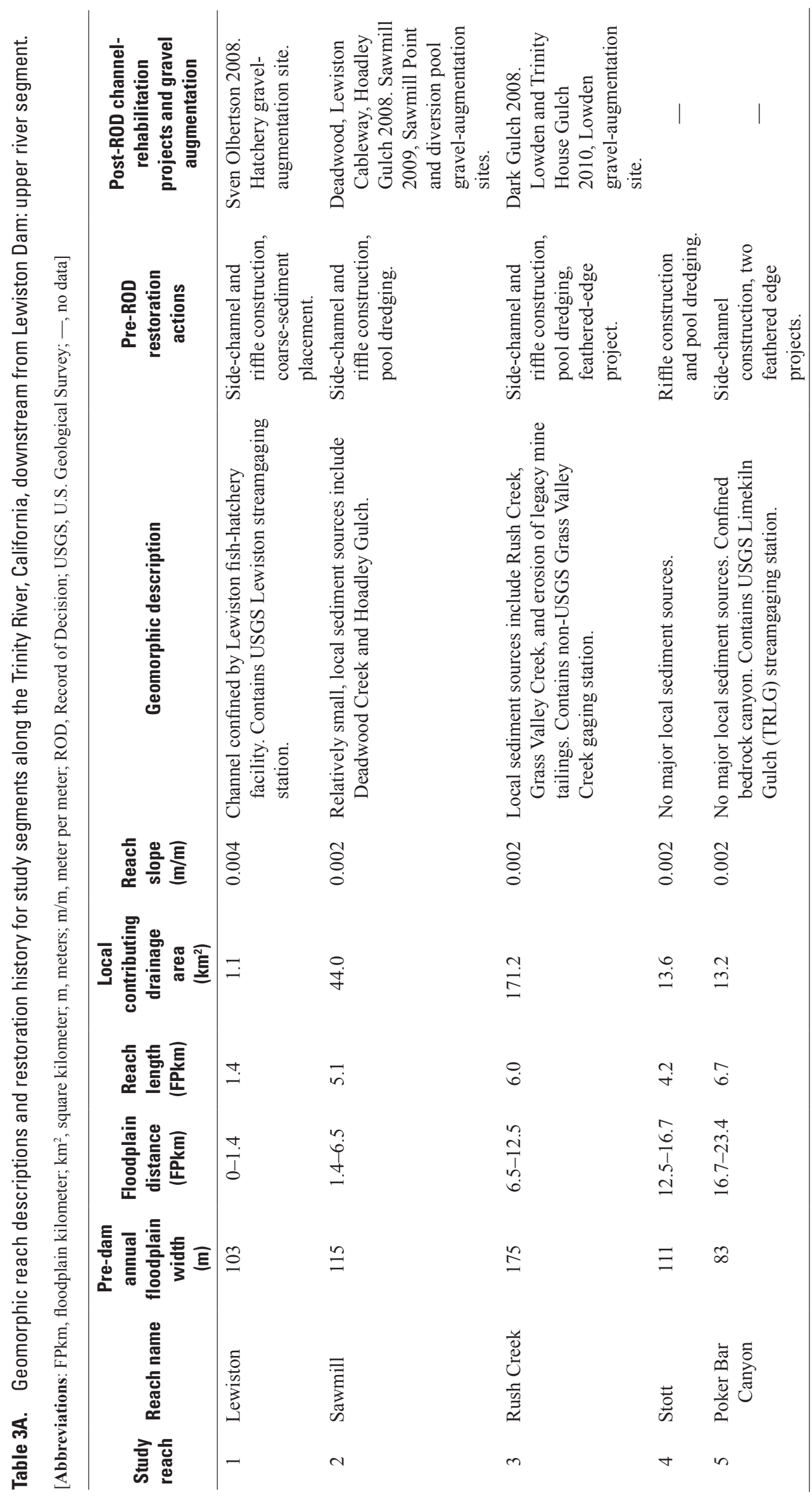



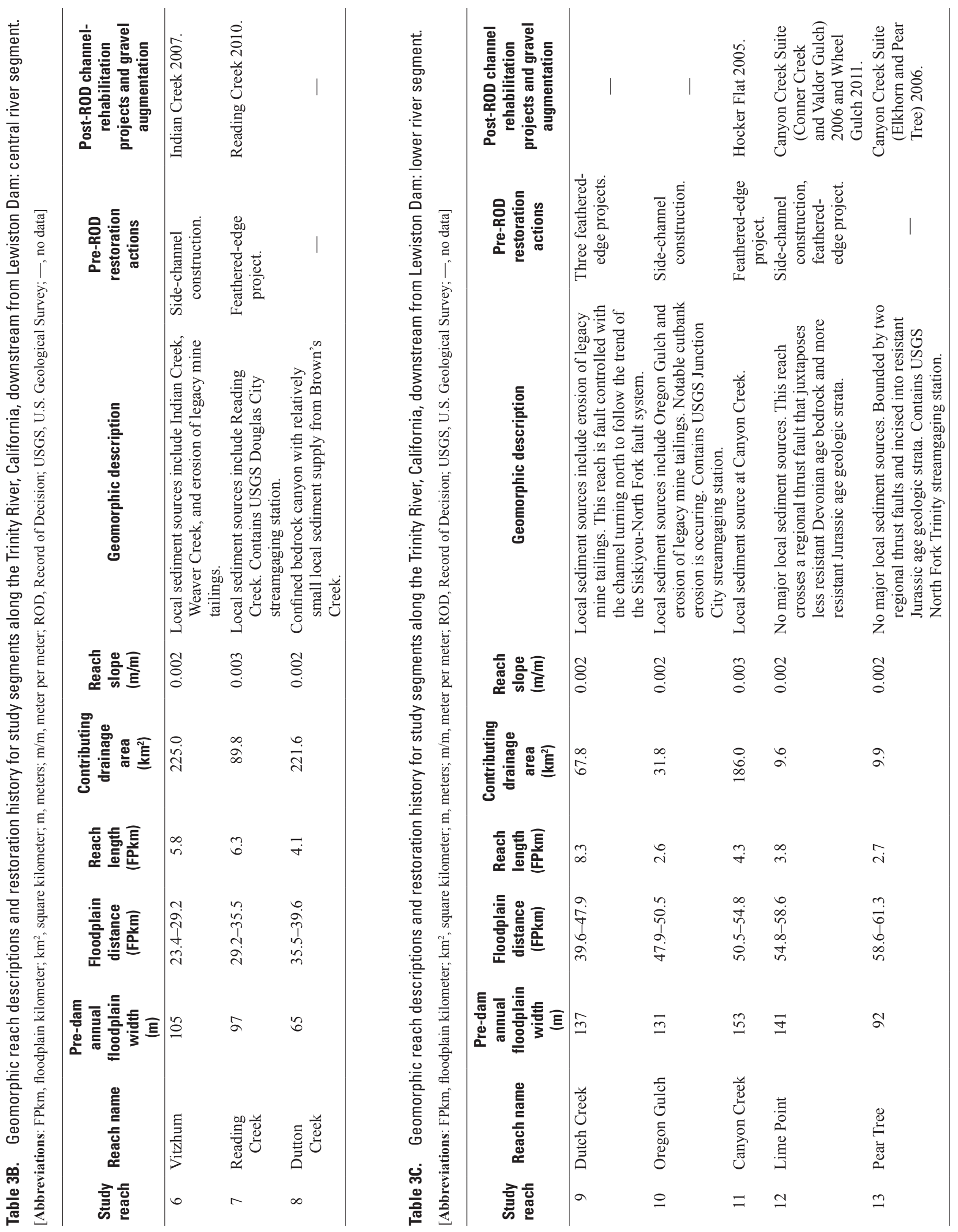
Table 4. Uncertainty analysis for six geomorphic maps of the Trinity River, California, downstream from Lewiston Dam.

[Note see Curtis and Guerrero (2015) for additional details. Abbreviations: $\mathrm{ft}^{3} / \mathrm{s}$, cubic feet per second; m, meters; mm/dd/yyyy, month/day/year; RMSE, root mean squared error]

\begin{tabular}{|c|c|c|c|c|c|c|}
\hline Year & $\begin{array}{c}\text { Date } \\
\text { (mm/dd/yyyy) }\end{array}$ & $\begin{array}{l}\text { Rectified orthophoto } \\
\text { resolution } \\
\text { (m) }\end{array}$ & $\begin{array}{l}\text { RMSE }^{1} \\
\text { (m) }\end{array}$ & $\begin{array}{c}\text { Stream discharge } \\
\text { at Lewiston gage } \\
\left(\mathrm{ft}^{3} / \mathrm{s}\right)\end{array}$ & $\begin{array}{l}\text { Difference in } \\
\text { water depth } \\
\qquad(\mathrm{m})\end{array}$ & $\begin{array}{c}\text { Inferred } \\
\text { digitizing error } \\
\text { (percent) }\end{array}$ \\
\hline 1980 & $05 / 16 / 1980$ & 0.6 & 9.8 & 288.0 & 0.0 & 10 \\
\hline 1997 & 10/20/1997 & 0.2 & 1.5 & 285.0 & 0.0 & 10 \\
\hline 2001 & $11 / 07 / 2001$ & 0.2 & 1.5 & 298.0 & 0.0 & 10 \\
\hline 2006 & $07 / 25 / 2006$ & 0.2 & 1.5 & 405.0 & 0.1 & 10 \\
\hline 2009 & $04 / 16 / 2009$ & 0.2 & 0.4 & 291.0 & 0.0 & 10 \\
\hline 2011 & 08/16/2011 & 0.2 & 0.2 & 446.0 & 0.1 & 10 \\
\hline
\end{tabular}

${ }^{1}$ Represents horizontal uncertainty for each ortho-rectified image.

${ }^{2}$ Error associated with variable discharge during photo acquisition estimated from gaging records.

${ }^{3}$ Digitizing error based on accuracy and precision of digitizing.

This value was inferred from pixel resolution and national accuracy standards (Curtis and Guerrero, 2015). We checked the alignment between the 1980 and1997 photography and concluded that $9.8 \mathrm{~m}$ represented an overly conservative estimate and determined that $5 \mathrm{~m}$ was a more representative estimate of RMSE. By using the less conservative RMSE of $5 \mathrm{~m}$, we estimated a threshold size of $25 \mathrm{~m}^{2}$ and rounded this up to $30 \mathrm{~m}^{2}$, which also represented the minimum polygon size for features included in the geodatabase. All change polygons smaller than $30 \mathrm{~m}^{2}$ were eliminated from the lateral-change analysis.

We did not explicitly quantify uncertainty associated with our geomorphic-change analyses because uncertainty is scale-and location dependent, but here we present some calculations that indicate the error associated with large wellexposed features was about 3 percent compared to about 10 percent for small, obscured features. Curtis and Guerrero (2015) determined digitized-line precision ranged from about 0.85 to $2.0 \mathrm{~m}$. This precision equated to a 7 to 13 percent error, or an average error of plus or minus 10 percent, for a representative 30-m channel width. The mean perimeter of active bars in 2011 was $130 \mathrm{~m}$, and active bars were typically well exposed, so application of the lowest linework precision (plus or minus $0.85 \mathrm{~m}$ ) was appropriate. For an equi-dimensional feature, with a perimeter of $130 \mathrm{~m}$ and area of $1,056 \mathrm{~m}^{2}$, the estimated uncertainty was within 3 percent.

\section{Assessing Natural and Managed Drivers of Geomorphic Change}

In fluvial systems, geomorphic change is driven by a complex set of interrelated causal mechanisms including numerous climatic, lithologic, topologic, biologic, and anthropogenic factors that often exist concurrently and sequentially, making it difficult to disentangle their relative importance. We specifically investigated the cumulative influence of streamflow, sediment supply, sediment management, and mechanical channel rehabilitation during the five study periods.

\section{Streamflow and Sediment Supply}

Flow analysis was limited by a lack of gaging records. We analyzed available records from the five mainstem gaging stations (fig. 2) and focused our analysis on the Lewiston gage, which has the longest period of record that spans the study period (table 5). We inferred ungaged tributary-flows by comparing mainstem-flows at stations upstream and downstream of tributary confluences. Our goal was to characterize the relative differences between mainstem flows during the five study periods. With this in mind, we assessed the magnitude, frequency, timing, and duration of flows and investigated the characteristics of geomorphically important flow events that took place in 1997, 1998, 2006, and 2011.

Previous investigations characterized the study reach as sediment-rich with abundant tributary sediment supplies (Pitlick and Wilcock, 2001). The exception to this generalization was in the upper river immediately downstream from Lewiston Dam, where post-dam sediment-deficit conditions existed (Gaeuman and Krause, 2010). The primary post-dam sediment sources, listed in order of importance, included tributary contributions, localized scour of in-channel sources, and gravel augmentation (Ritter, 1968; Knott, 1974; Trinity River Taskforce, 1979; Trinity Restoration Associates, Inc., 1993; Graham Matthews and Associates, 2001; Pitlick and Wilcock, 2001; Gaeuman and Krause, 2010).

Although there has been extensive monitoring of mainstem sediment transport in the upper river since 2005 (Graham Matthews and Associates, 2012), few measured data were available for the pre-2005 periods. Without direct measurements, sediment supply could only be evaluated indirectly. We assumed there was no supply of bed-materialsized sediment (greater than $0.5 \mathrm{~mm}$ ) from sources upstream of Lewiston Dam. We then assumed a positive correlation between flow and sediment supply and inferred an increase in sediment supply with increasing mainstem flow. 


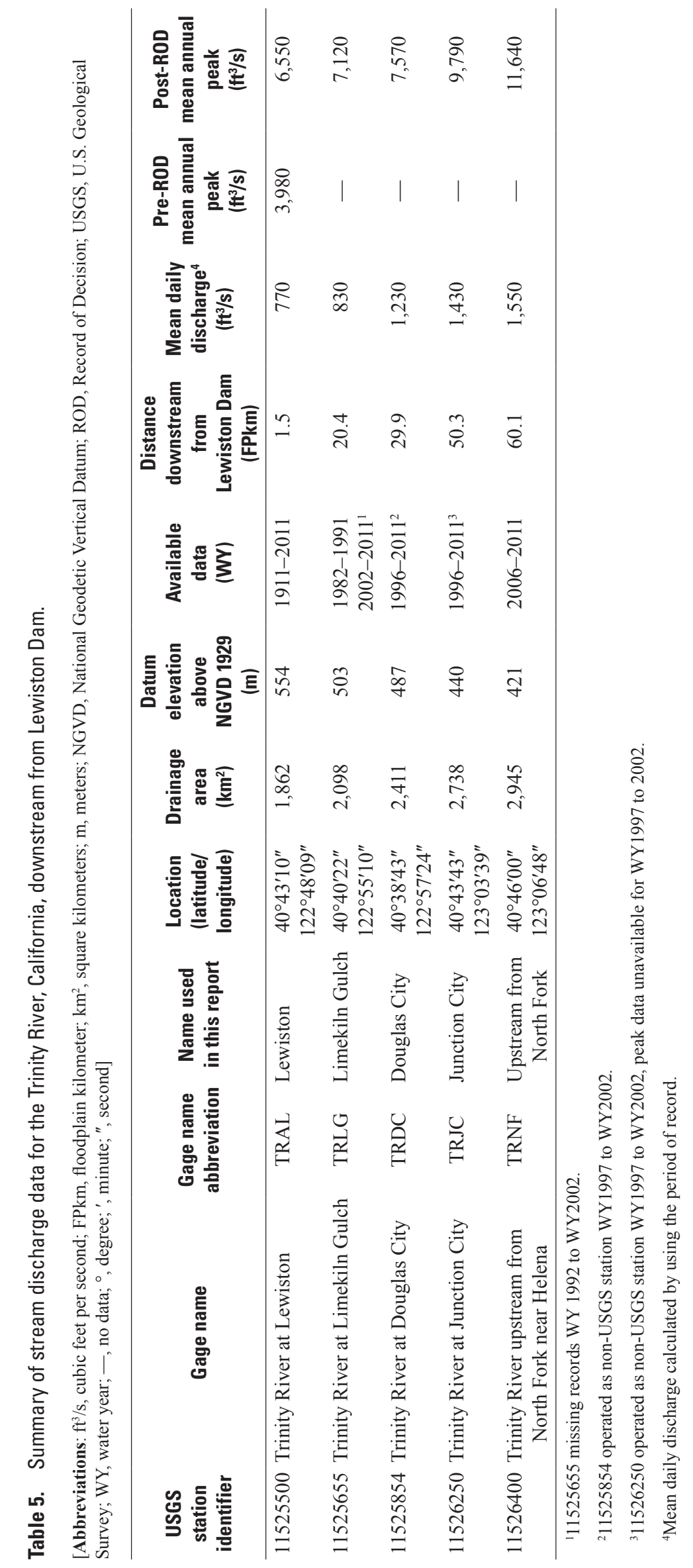




\section{Sediment Management and Mechanical Channel Rehabilitation}

We compiled, analyzed, and summarized information related to sediment management and mechanical rehabilitation from available reports (Kondolf and Minear, 2004; Gaeuman, 2008; Gaeuman and Krause, 2011; Hoopa Valley Tribe and others, 2011b; Graham Matthews and Associates, 2012; Krause, 2012b) and from communication with TRRP staff. A lack of "as built" surveys, which reflect any changes made during construction, required that we use the original design specifications to identify the location and extent of constructed features. The digitized extent of constructed features do not always represent the actual "as built" extents because geomorphic changes could have occurred between construction and photo acquisition. Although these data required little analysis, they were critical for interpreting management actions that altered river morphology.

\section{Results}

Our results focus on spatial and temporal trends in the areal distribution of geomorphic features. The mapping data represent channel conditions at discrete points in time, whereas estimates of geomorphic change represent the cumulative response to numerous controlling factors during each study period. We present estimates of cumulative geomorphic change, describe controlling factors, and assess the primary causal mechanisms that created geomorphic change during each of the five study periods. The areal extent of individual geomorphic features, summarized for each of the thirteen geomorphic reaches, is presented in appendix A.

\section{Spatial and Temporal Analysis of Geomorphic Change}

When the areal extent of the riparian and channel environments were compared at the system-scale geomorphic change was not apparent because large riparian features dominated the landscape (fig.6A). In particular, the riparian environment was dominated by the pre-dam floodplain. The active-channel margin represents the boundary between riparian and channel features. In figures $6 B$ to $6 F$, the change in active-channel area is shown for the five periods of interest. An increase in the active-channel area equated to an equal loss of riparian area, and likewise a decrease in the active-channel area equated to an equal increase in riparian area.

Excluding the pre-dam floodplain and focusing on smaller-scale lower-elevation features highlighted spatial and temporal changes in riparian diversity (fig. 7). In
1980, post-dam benches composed 94 percent of the lower elevation riparian environment (fig. 7 A). By 2001, floodplain construction and bar stabilization increased riparian diversity, and the proportion of post-dam benches decreased to 86 percent (fig. 7 C). By the end of the study period in 2011, the relative proportions of post-dam benches, constructed floodplains, stable bars, and riparian wetlands were 60, 27, 10 and 3 percent, respectively (fig. $7 F$ ).

The diversity of channel features was more variable than riparian features in space and time (fig. 8). In 1980, channel diversity was greatest in the upper and central river reaches and channel-complexity features, such as active bars and secondary water features (split-flow channels, side channels, alcoves, and aquatic wetlands), composed approximately 12 percent of the active-channel area (fig. $8 A$ ). From 1980 to 2001, the active-channel area increased by 20 percent (fig.6). By 2001, there were relatively more channel complexity features in the upper and central river reaches (fig. $8 B$ ) and these features composed 17 percent of the active-channel area. From 2001 to 2011, the increase in active-channel area was about 5 percent. By 2011, channel complexity had increased in the upper river, but decreased in the lower river. By 2011, the channel-complexity features occupied 14 percent of the active-channel area (fig. $8 F$ ). During the longer (21 years) and relatively wetter pre-ROD period, increases in activechannel area and channel complexity were 20 and 70 percent, respectively. The post-ROD period was shorter (10 years) and relatively drier, with intensified management. During this later period, there were smaller, but measurable, increases in active-channel area of about 5 percent, and channel complexity decreased by 3 percent.

Spatial and temporal changes in geomorphic features are illustrated in greater detail in this section and are used to interpret trajectories and rates of geomorphic change during the five study periods. We present summary data for individual upland, riparian, or channel features in the context of the 13 geomorphic reaches and the upper, central, and lower river segments, as defined in table 3 . In each figure, panel A shows the cumulative area of each geomorphic feature summed in the downstream direction from Lewiston Dam to the confluence with the North Fork Trinity River; panel B shows cumulative change in feature area per year, where the slope of the line represents and annual rate of change; and panel C shows a time series of feature area scaled by reach length and illustrates trajectories of change. Note the differences in the scale of the y-axis in these figures.

Uplands showed little cumulative change during the study period (fig. 9), particularly when compared to changes in total riparian area (fig. 10) and individual riparian features (figs. 11-14). The exception to this generality was Reach 3 (fig. 9B), where uplands were converted to constructed floodplains by mechanical surface lowering from 2009 to 2011 . 

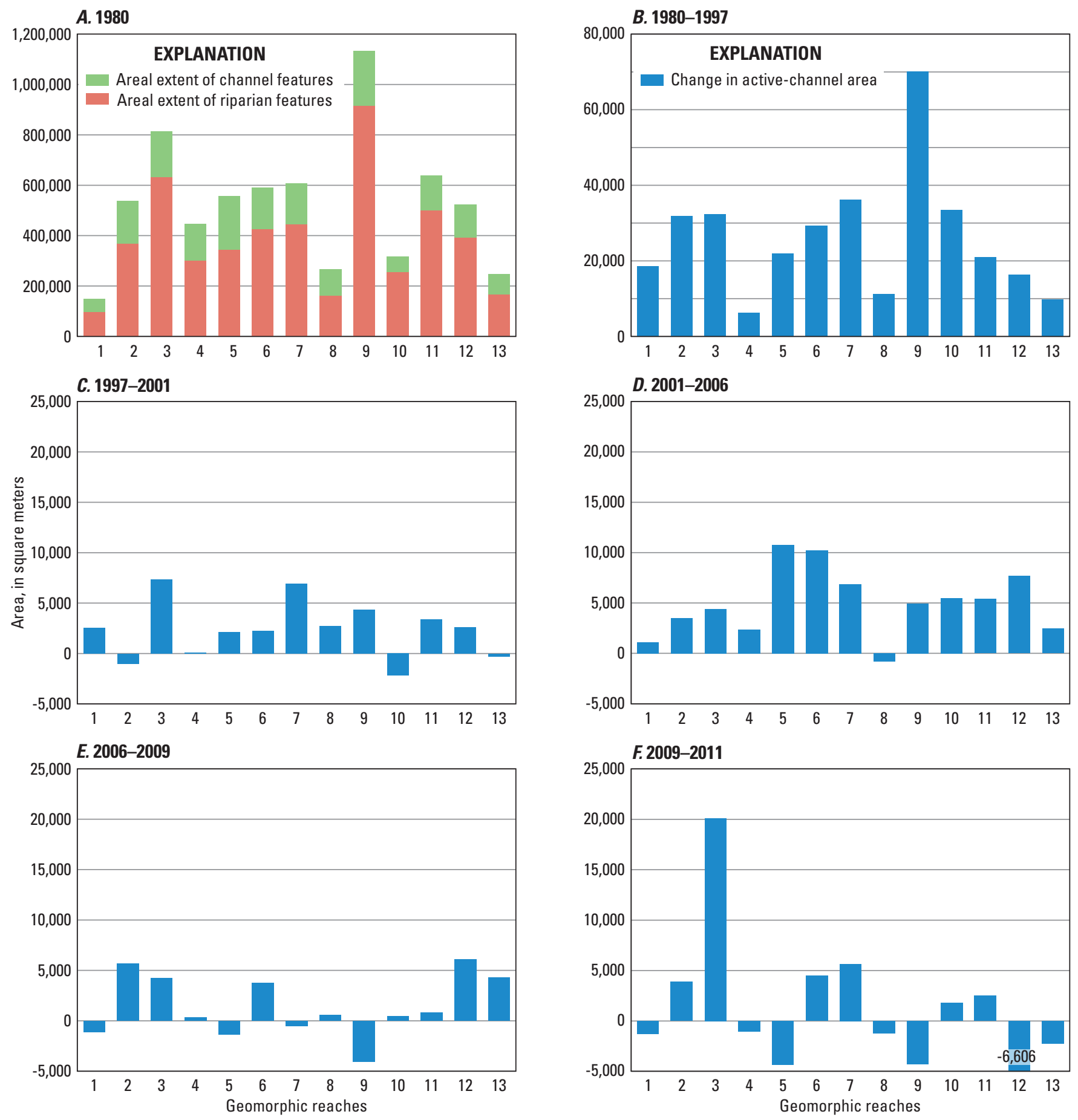

Figure 6. Areal extent of riparian and channel features along the Trinity River downstream from Lewiston Dam, California, $A$, in 1980, and change in active-channel area for five periods from 1980 to 2011: $B, 1980$ to 1997; C, 1997 to 2001; $D, 2001$ to 2006; $E$, 2006 to 2009; and $F, 2009$ to 2011. Note differences in y-axis scale among periods. 

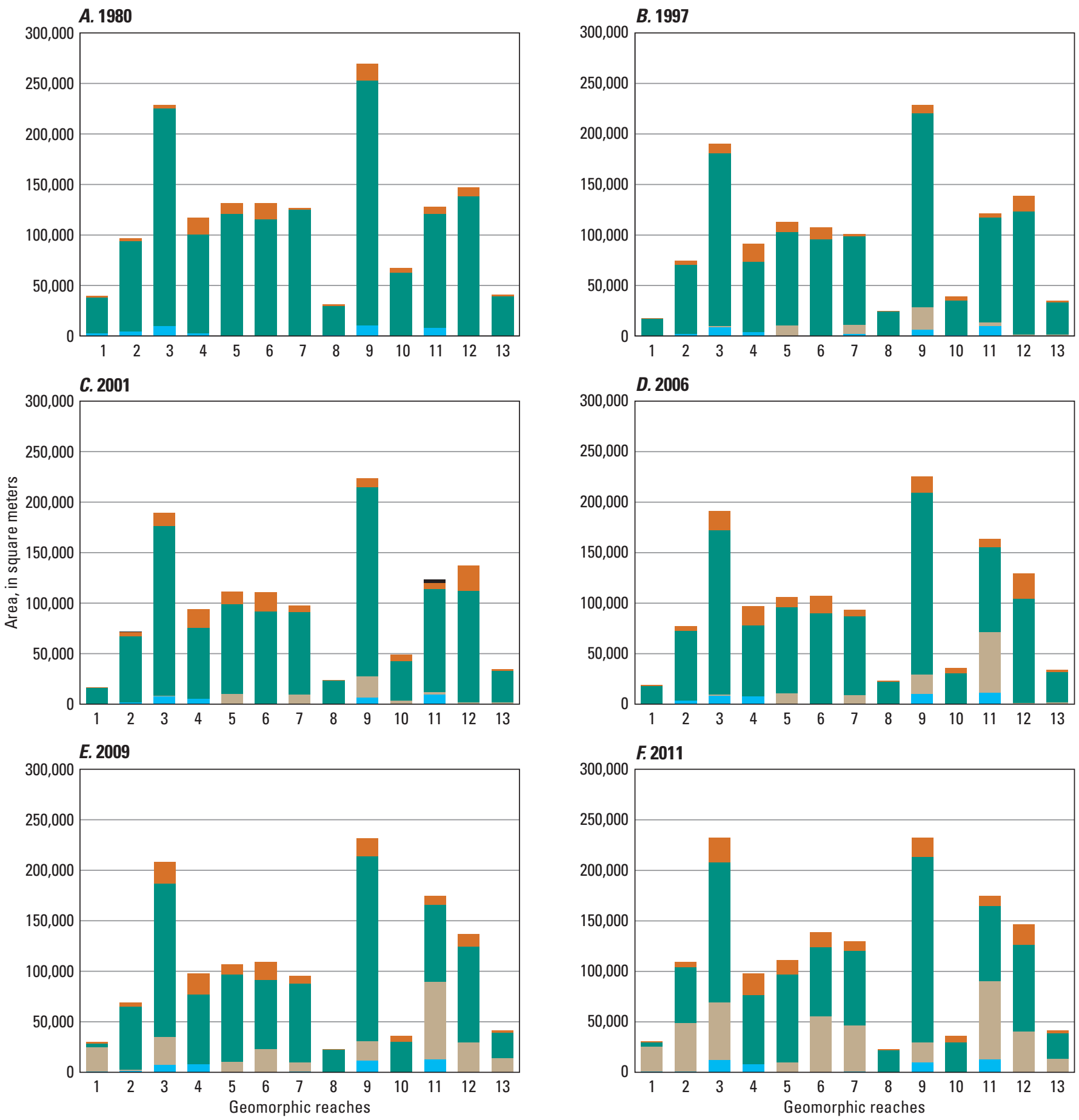

\section{EXPLANATION}

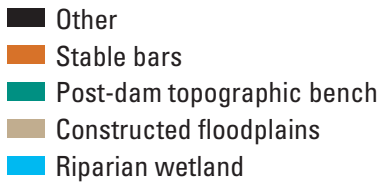

Figure 7. Areal extent of lower elevation riparian features along the Trinity River downstream from Lewiston Dam, California, in $A, 1980 ; B, 1997 ; C, 2001 ; D, 2006 ; E, 2009$; and $F, 2011$. 

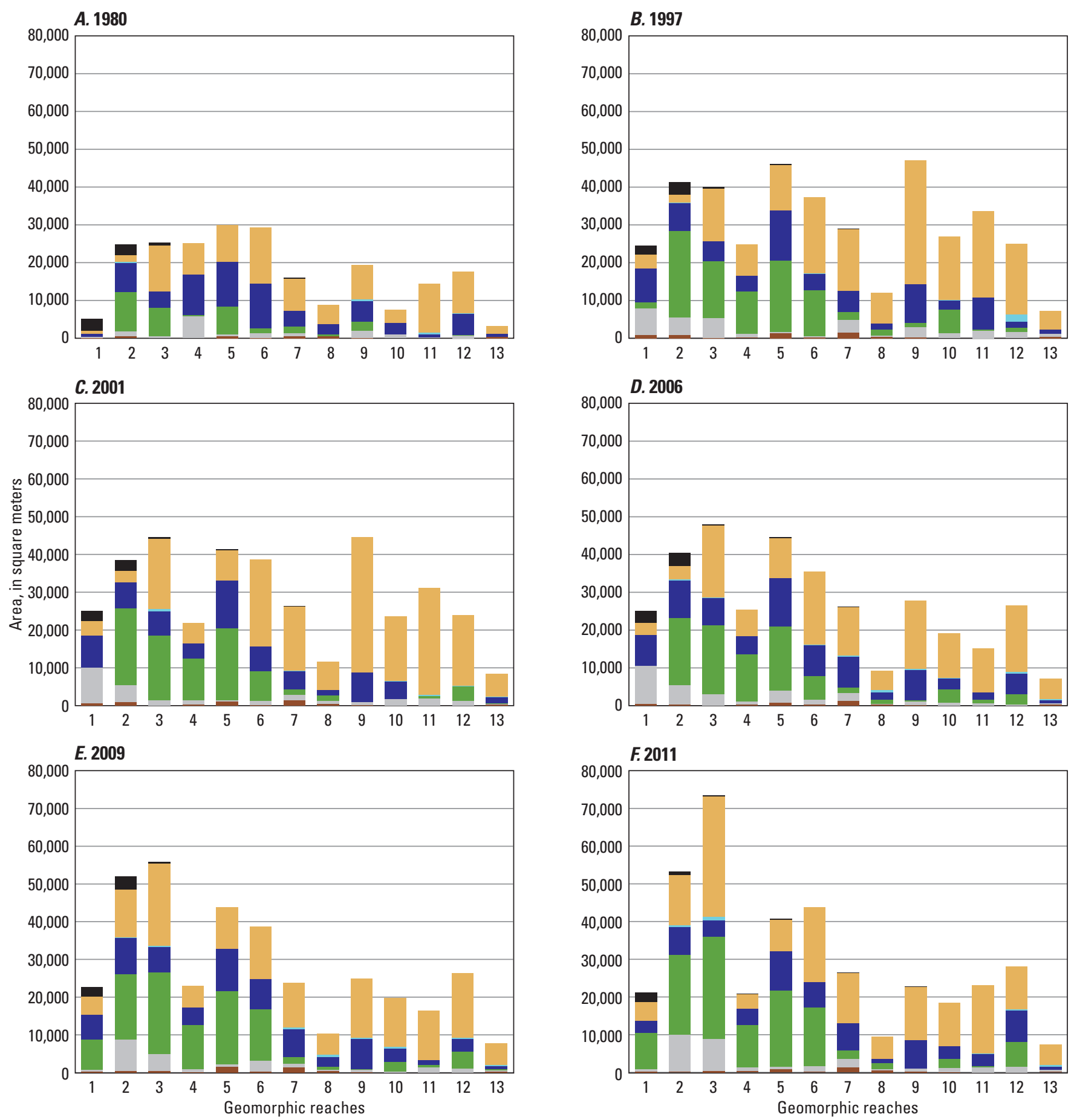

\section{EXPLANATION}

Other

Active bars

Aquatic wetland

- Split-flow channel

Side channel

Alcove

Exposed bedrock

Figure 8. Areal extent of channel-complexity features within the active channel along the Trinity River downstream from Lewiston Dam, California, in A, 1980; B, 1997; C, 2001; D, 2006; E, 2009; and F, 2011. 
Uplands

\begin{tabular}{c|c|c|c|c|c|c|c|c|c|c|c|c|c|c|}
$\begin{array}{c}\text { Geomorphic } \\
\text { reach } \\
\begin{array}{c}\text { Tributary } \\
\text { confluence }\end{array}\end{array}$ & R1 & R2 & & R3 & R4 & R5 & R6 & R7 & R8 & R9 \\
\hline
\end{tabular}
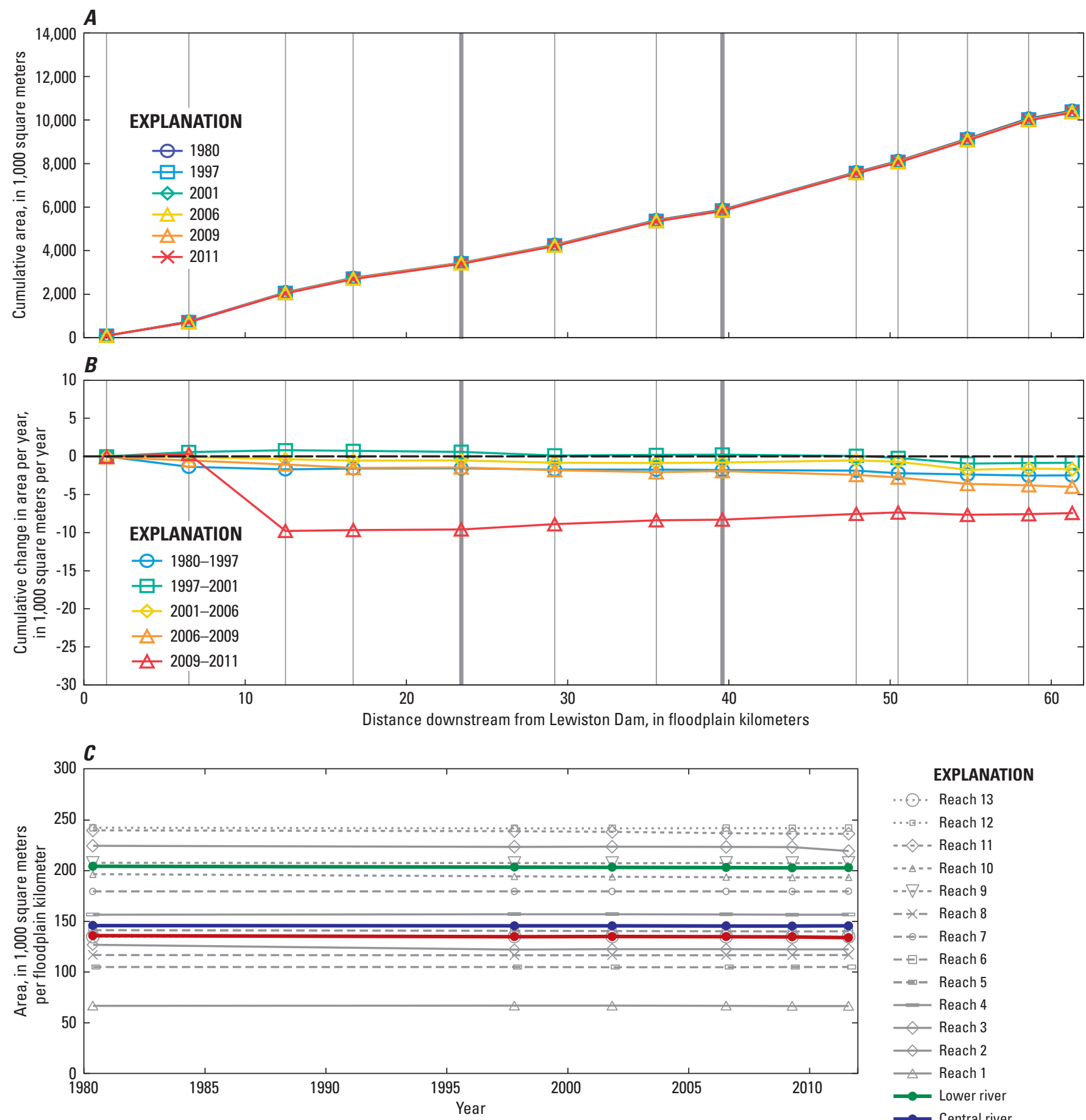

EXPLANATION

. - .). Reach 13

.... . Reach 12

$-\prec-$ Reach 11

$=-\Delta=-$ Reach 10

- - $\nabla$ - - Reach 9

$-\star x-$ Reach 8

$-\ominus-$ Reach 7

$-\boxminus-$ Reach 6

$-\square-$ Reach 5

- Reach 4

$\checkmark$ Reach 3

$\smile$ Reach 2

$\triangle$ Reach 1

$\longrightarrow$ Lower river

$\longrightarrow$ Central river

- Upper river

R8 Geomorphic reach

+ Tributary confluence

Figure 9. Area of uplands along the Trinity River downstream from Lewiston Dam, California, and change in upland area from 1980 to 2011: $A$, cumulative area by reach; $B$, cumulative change in area per year by reach; $C$, area by study reach and segments over time. 
Riparian features

\begin{tabular}{|c|c|c|c|c|c|c|c|c|c|c|c|c|c|}
\hline $\begin{array}{r}\text { Geomorphic } \\
\text { reach } \\
\text { Tributary } \\
\text { confluence }\end{array}$ & R1 & $\mathbf{R 2}$ & R3 & R4 & R5 & $\begin{array}{r}\text { R6 } \\
+\end{array}$ & R7 & $\begin{array}{l}\text { R8 } \\
+\end{array}$ & R9 & $\begin{array}{r}\text { R10 } \\
+\end{array}$ & $\begin{array}{r}\text { R11 } \\
+\quad\end{array}$ & R12 & R13 \\
\hline
\end{tabular}
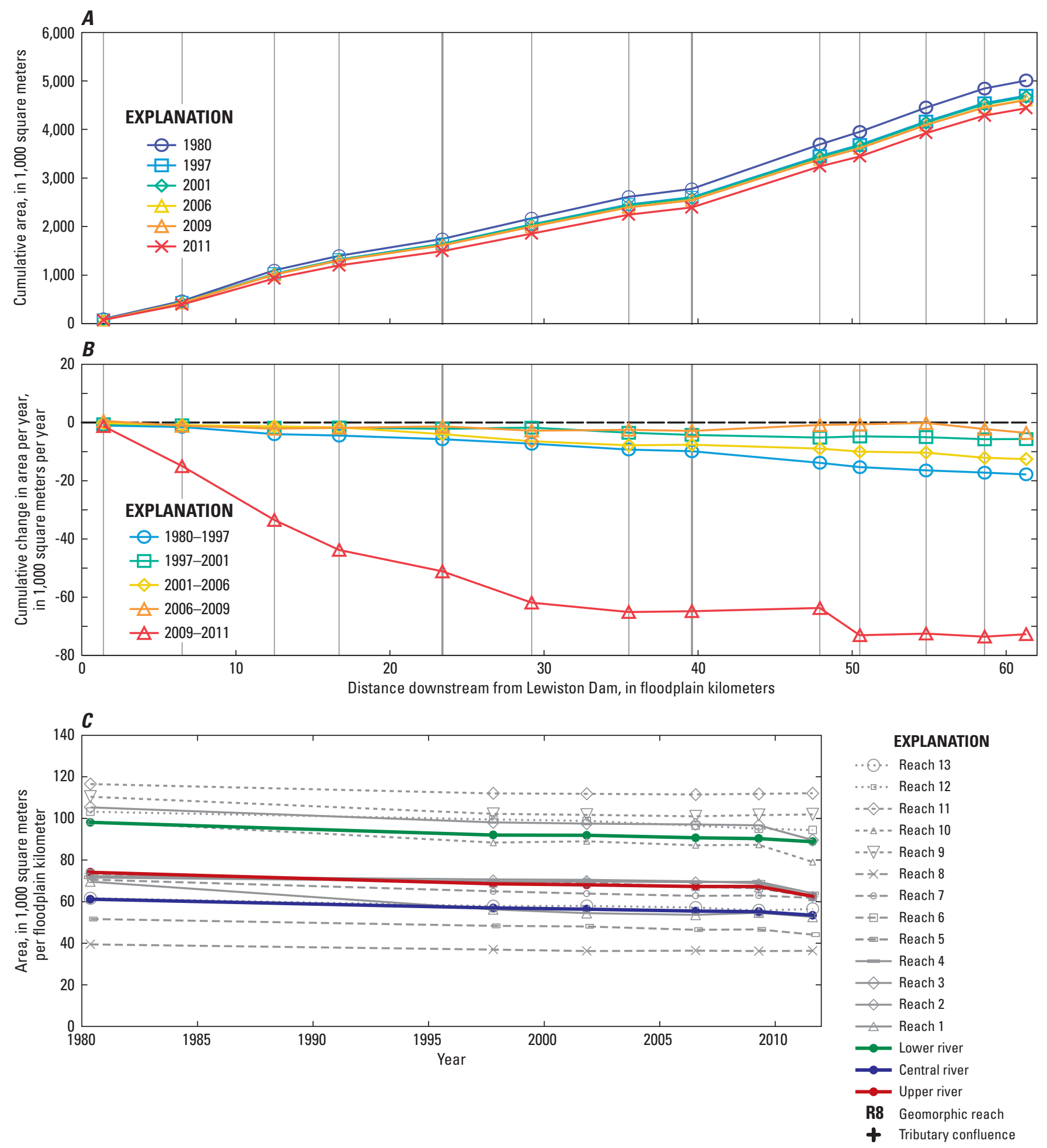

Figure 10. Area of riparian features along the Trinity River downstream from Lewiston Dam, California, and change in riparian area from 1980 to 2011: $A$, cumulative area by study reach; $B$, cumulative change in area per year by study reach; $C$, area by study reach and segments over time. 
Riparian area generally decreased during the study period, but the decrease accelerated after 2009 (fig. 10B). The post-2009 decrease in riparian area was primarily caused by conversion of a large portion of pre-dam floodplain (fig. 11B) into a series of constructed floodplains by mechanical surface lowering. The area of post-dam benches also decreased during the study period, with the largest cumalative decreases from 1980 to 1997 (fig. 12A) caused by bank erosion and bar scour. Post-dam benches were also converted into constructed floodplains by vegetated berm removal and mechanical surface lowering. Floodplain construction accelerated during the post-ROD period, especially after 2006 (fig. 13).

Stable bars are transitional units, originally deposited in the active channel, but are part of the riparian environment when stabilized by vegetation and revert back to the active channel when scoured and remobilized. Bar stabilization accelerated from 1997 to 2001(fig. 14A), and the area of stable bars continued to increase until the end of the study period in 2011 (fig. 14C). The exception to this generalization was a decrease in stable bar area from 2006 to 2009 in the lower river caused by the 2006 tributary-flow event.

The active-channel area generally increased during the study period as upland and riparian features were eroded or mechanically altered. The largest cumulative increase in active-channel area occurred from 1980 to 1997 (fig. 15A). When cumulative change is scaled by time (fig. $15 B$ ), the highest rate of change in the upper river was in Reach 3 during the relatively short period from 2009 to 2011 . This period included the 2011 flow release, the largest since 1974 (Krause, 2012a), and several large scale TRRP bank rehabilitation projects. The cumulative change in active-channel area across the study area from 2009 to 2011 was slightly less than the rate estimated for the much longer and relatively wetter period from 1980 to 1997.

The largest cumulative increase in active-bar area occurred between 1997 and 2001, primarily downstream from Indian Creek (25.6 percent; fig. 16A). Post-2001 changes in active-bar area were variable across the study area. From 2001 to 2006 , there was a slight increase in active-bar area in the upper river (fig. 16B). With the start of gravel augmentation by direct injection in 2008, active-bar area increased notably in the upper river between 2006 and 2011 (fig. 16C). From 2001 to 2009, active-bar area decreased in the central river, which was followed by an increase from 2009 to 2011. From 2001 to 2006 , active bar area decreased notably in the lower river, then remained relatively stable from 2006 to 2009, and decreased slightly from 2009 to 2011 (fig. 16C).

We combined the area of secondary water features (split-flow channels, side channels, alcoves, and aquatic wetlands) into a single category for analysis because the trajectories of change for these small features were highly variable. There were large increases in the area of secondary water features from 1980 to 1997 (fig. 17A), primarily in the upper river. The area of secondary water features remained fairly static after 1997 (fig.17A), and there were minor decreases from 1997 to 2001, primarily in the central and lower river (fig. 17B). From 2001 to 2006 and 2006 to 2009, there were small increases in the area of secondary water features primarily in the central river, and from 2009 to 2011, there were larger increases in the area of secondary water features primarily in the lower river (fig. 17C). Trends in shoreline length were similar to those for secondary water features (fig. 18A).

From 1980 to 2006, average active-channel widths increased in all the study reaches (fig. 18B). In 1980, the active channel width was much greater in the upper river, but by 1997, active-channel widths in the upper and lower river were about equal and remained similar for the remainder of the study period. Channel widths continued to increase from 1997 to 2006, but remained stable from 2006 to 2009. From 2009 to 2011, channel widths decreased slightly in the upper and lower river and increased slightly in the central river.

\section{Natural and Managed Drivers of Geomorphic Change}

Sediment retention by upstream dams, flow diversion, and flow regulation led to diminished sediment supply and transport capacity, particularly in the reach that extends from Lewiston Dam downstream to Rush Creek (0-6.5 FPkm). Further downstream, sediment supply from Grass Valley Creek $(11.85 \mathrm{FPkm})$ was effectively eliminated by sediment retention dams constructed in 1986 (Trinity River Taskforce, 1970). These retention ponds are actively maintained by dredging, under the present sediment-management program (Krause, 2012b). Although Deadwood Creek (1.65 FPkm) and Rush Creek (6.5 FPkm) contribute flow and sediment, transport capacity remains low downstream to Poker Bar Canyon, where channel confinement and transport capacity increase as the river flows through a confined bedrock canyon (16.7-23.4 FPkm).

Contributing drainage area, sediment supply, and flow increase in the central river as a result of tributary contributions from Indian Creek (25.6 FPkm), Weaver Creek (28.0 FPkm), and Reading Creek (29.4 FPkm) and localized bank erosion of legacy mine tailings. Further downstream, the central river flows through a second confined bedrock reach (35.5-39.6 FPkm), where transport capacity increases, but sediment supply diminishes. 
Pre-dam floodplain

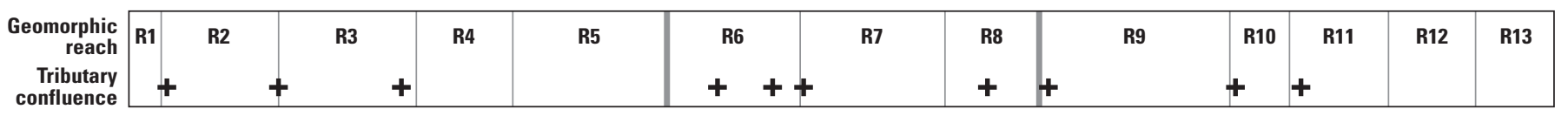
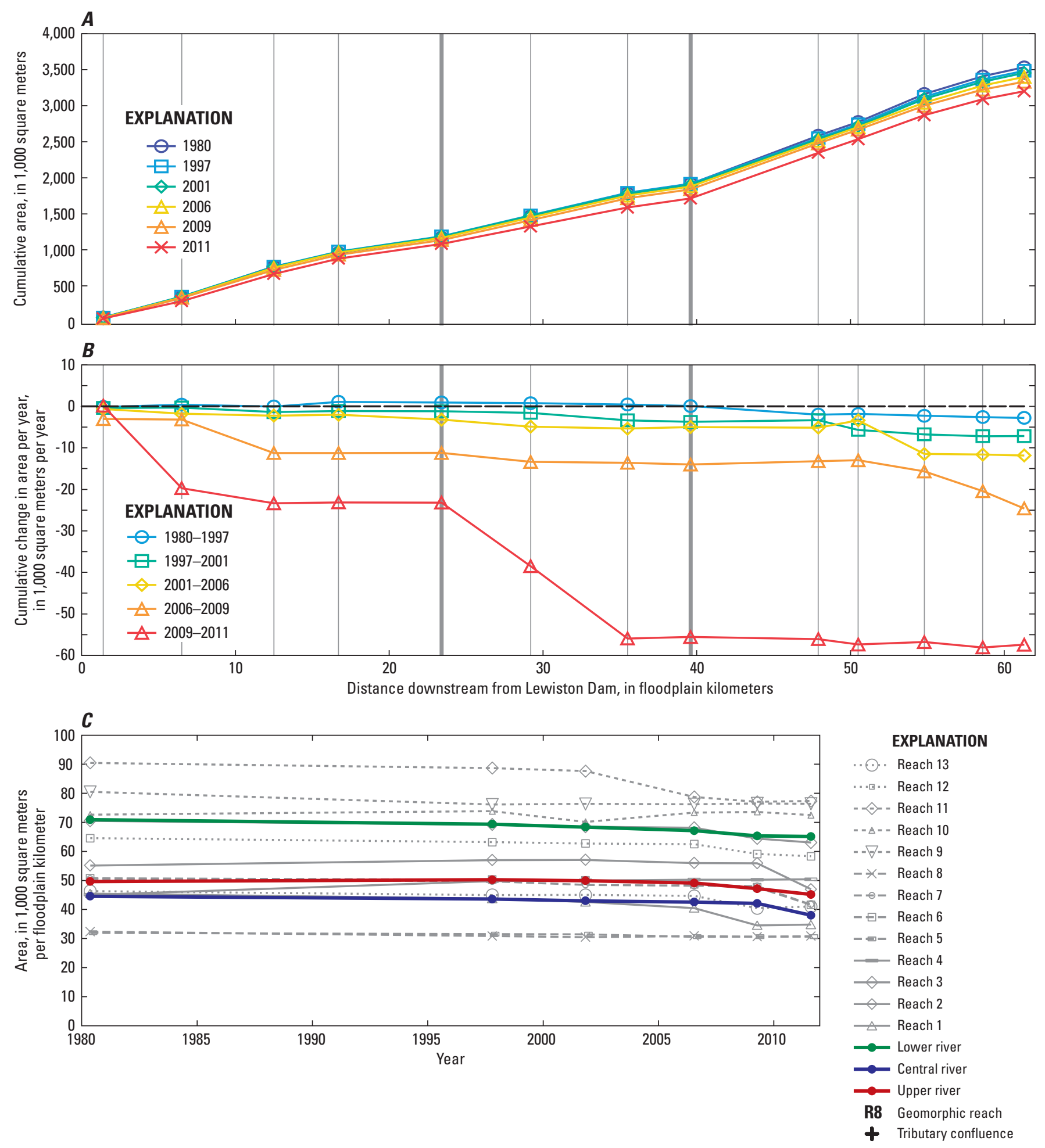

Figure 11. Area of the pre-dam floodplain along the Trinity River downstream from Lewiston Dam, California, and change in pre-dam floodplain area from 1980 to 2011: A, cumulative area by study reach; $B$, cumulative change in area per year by study reach; $C$, area by study reach and river segments over time. 
Post-dam topographic benches

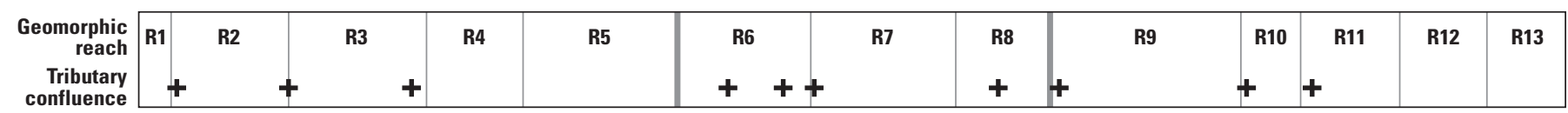
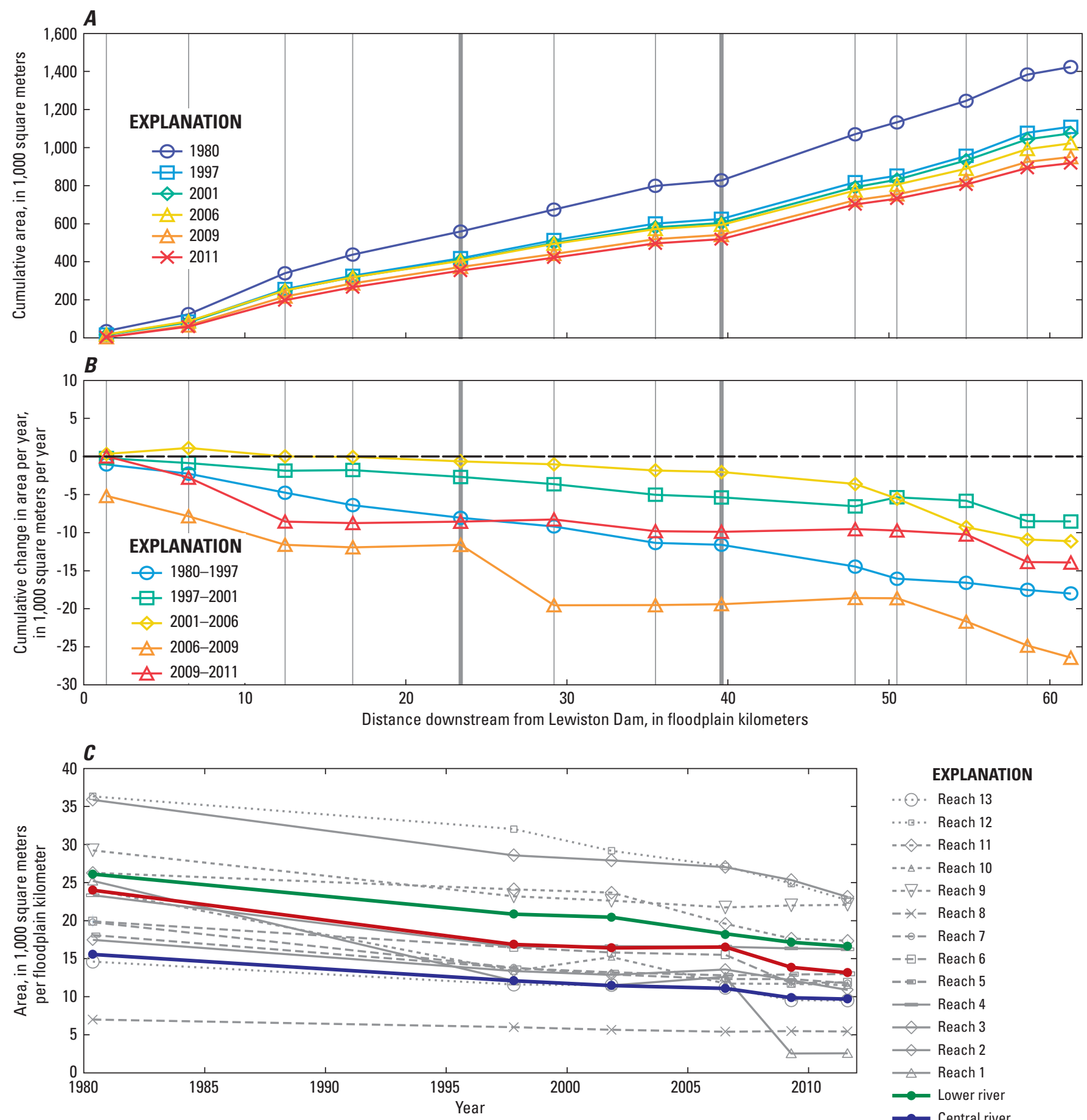

EXPLANATION

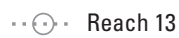

... [.. Reach 12

$-\diamond-$ Reach 11

$=-\Delta=-$ Reach 10

- - $\nabla$ - - Reach 9

$-\star x-$ Reach 8

$-\ominus-$ Reach 7

$-\boxminus-$ Reach 6

$-\square-$ Reach 5

- Reach 4

$\checkmark$ Reach 3

$\leadsto$ Reach 2

$\triangle$ Reach 1

- Lower river

$\longrightarrow$ Central river

- Upper river

R8 Geomorphic reach

+ Tributary confluence

Figure 12. Area of post-dam benches along the Trinity River downstream from Lewiston Dam, California, and change in post-dam bench area from 1980 to 2011: $A$, cumulative area by study reach; $B$, cumulative change in area per year by study reach; $C$, area by study reach and river segments over time. 
Constructed floodplains

\begin{tabular}{|c|c|c|c|c|c|c|c|c|c|c|c|c|c|}
\hline $\begin{array}{r}\text { Geomorphic } \\
\text { reach } \\
\text { Tributary }\end{array}$ & R1 & R2 & R3 & R4 & R5 & $\begin{array}{r}\text { R6 } \\
+\end{array}$ & R7 & $\begin{array}{l}\mathbf{R 8} \\
+\end{array}$ & R9 & $\begin{array}{l}\text { R10 } \\
+\end{array}$ & $\begin{array}{r}\text { R11 } \\
+\quad\end{array}$ & R12 & R13 \\
\hline
\end{tabular}
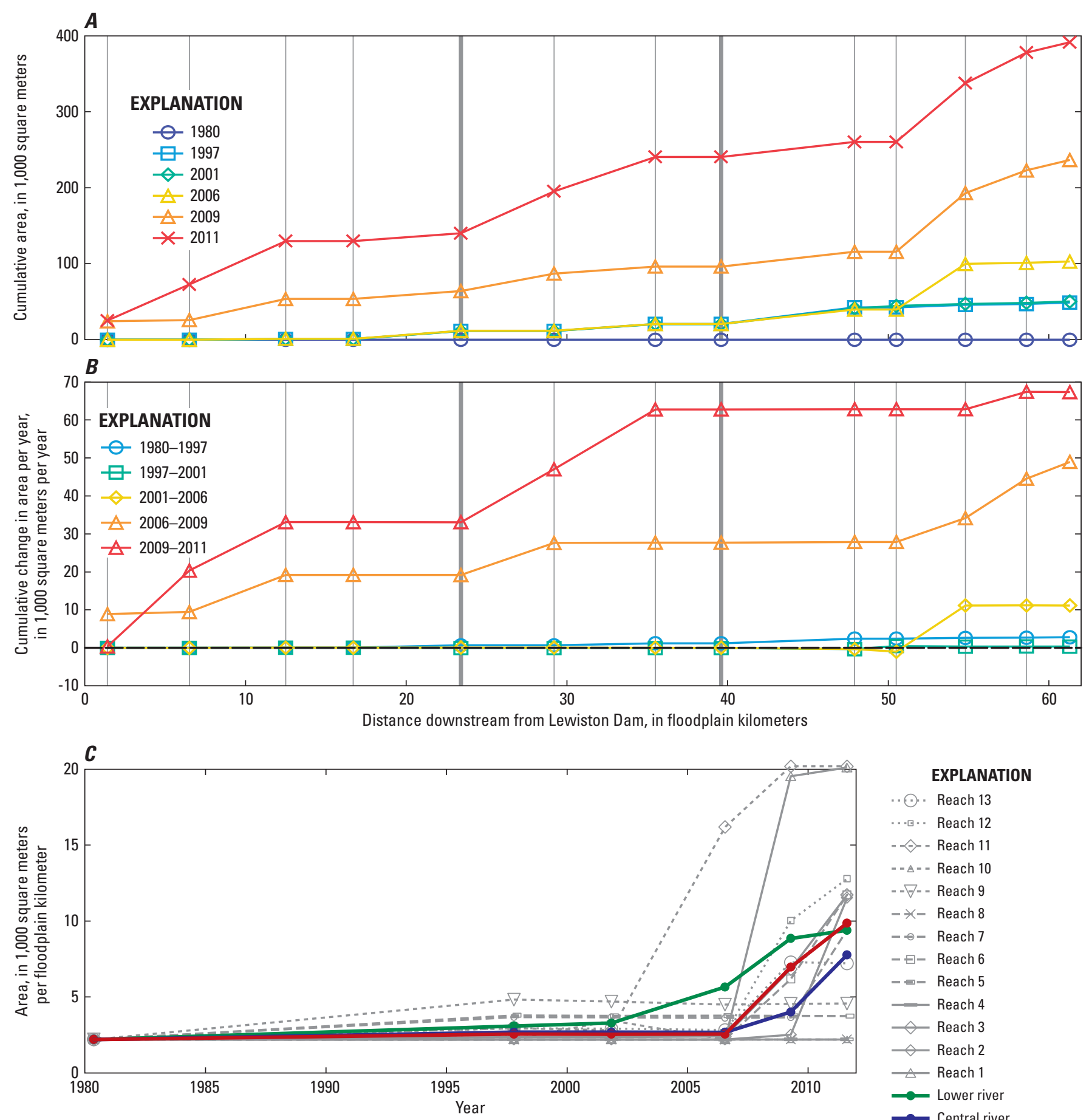

EXPLANATION

\section{$\therefore$. Reach 13}

.... . Reach 12

$-\diamond-$ - Reach 11

$=-\Delta=-$ Reach 10

$--\nabla--$ Reach 9

$-\nsucc-$ Reach 8

$-\ominus-$ Reach 7

$-\boxminus-$ Reach 6

-- Reach 5

- Reach 4

$\checkmark$ Reach 3

$\checkmark$ Reach 2

$\triangle$ Reach 1

$\longrightarrow$ Lower river

$\longrightarrow$ Central river

$\longrightarrow$ Upper river

R8 Geomorphic reach

+ Tributary confluence

Figure 13. Area of constructed floodplains along the Trinity River downstream from Lewiston Dam, California, and change in constructed floodplain area from 1980 to 2011: $A$, cumulative area by study reach; $B$, cumulative change in area per year by study reach; $C$, area by study reach and river segments over time. 
Stable bars

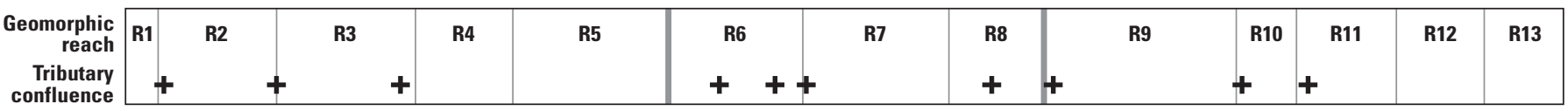
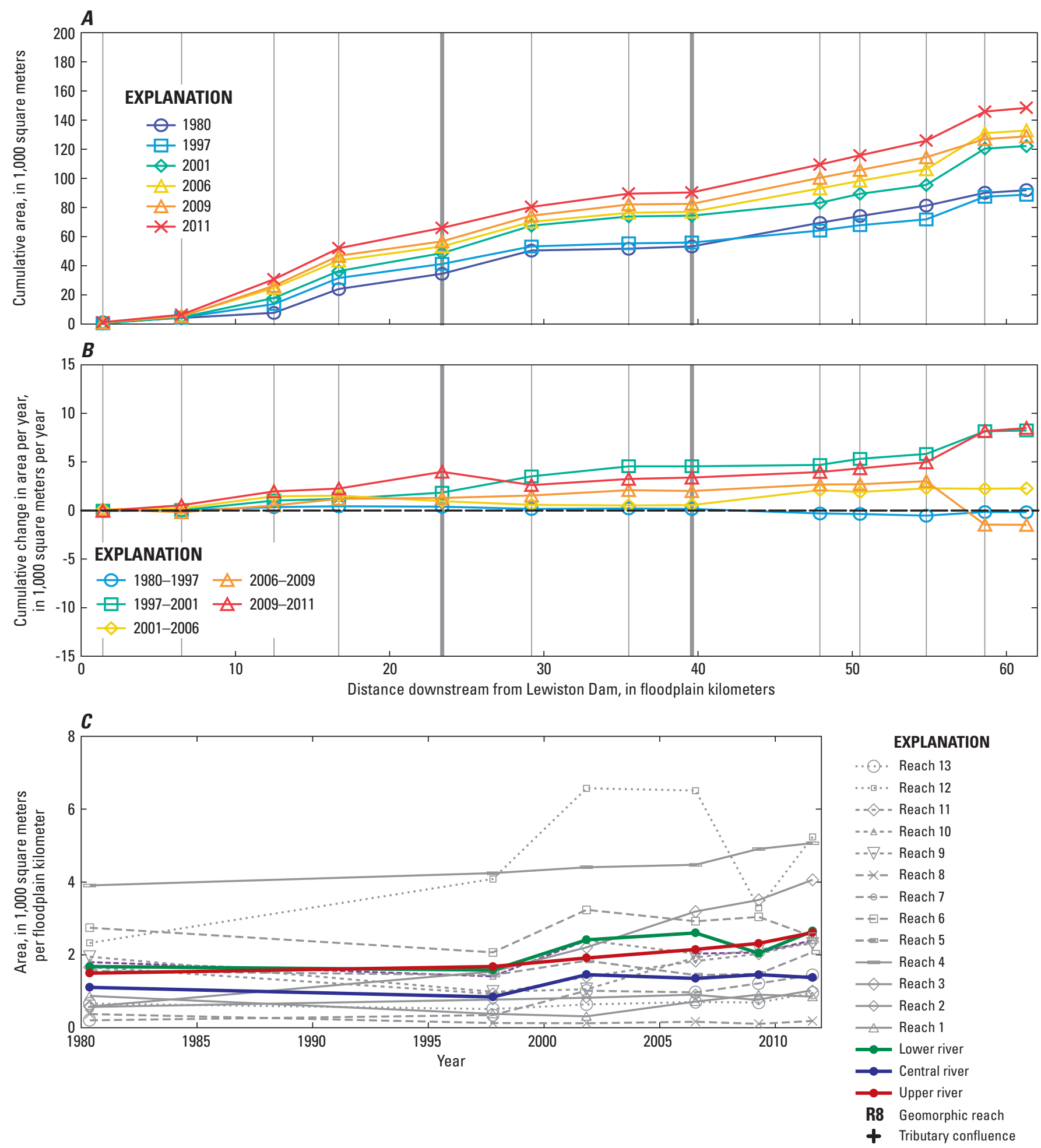

Figure 14. Area of stable bars along the Trinity River downstream from Lewiston Dam, California, and change in stable bar area from 1980 to 2011: $A$, cumulative area by study reach; $B$, cumulative change in area per year by study reach; $C$, area by study reach and river segments over time. 
Active-channel area

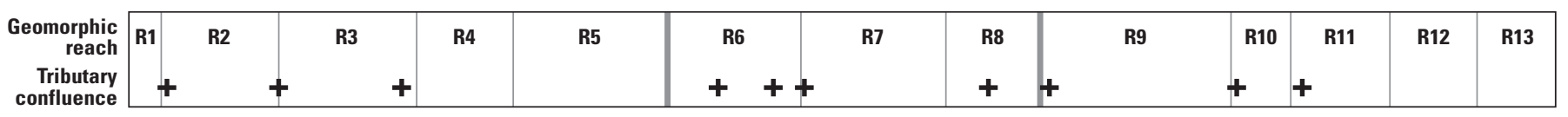
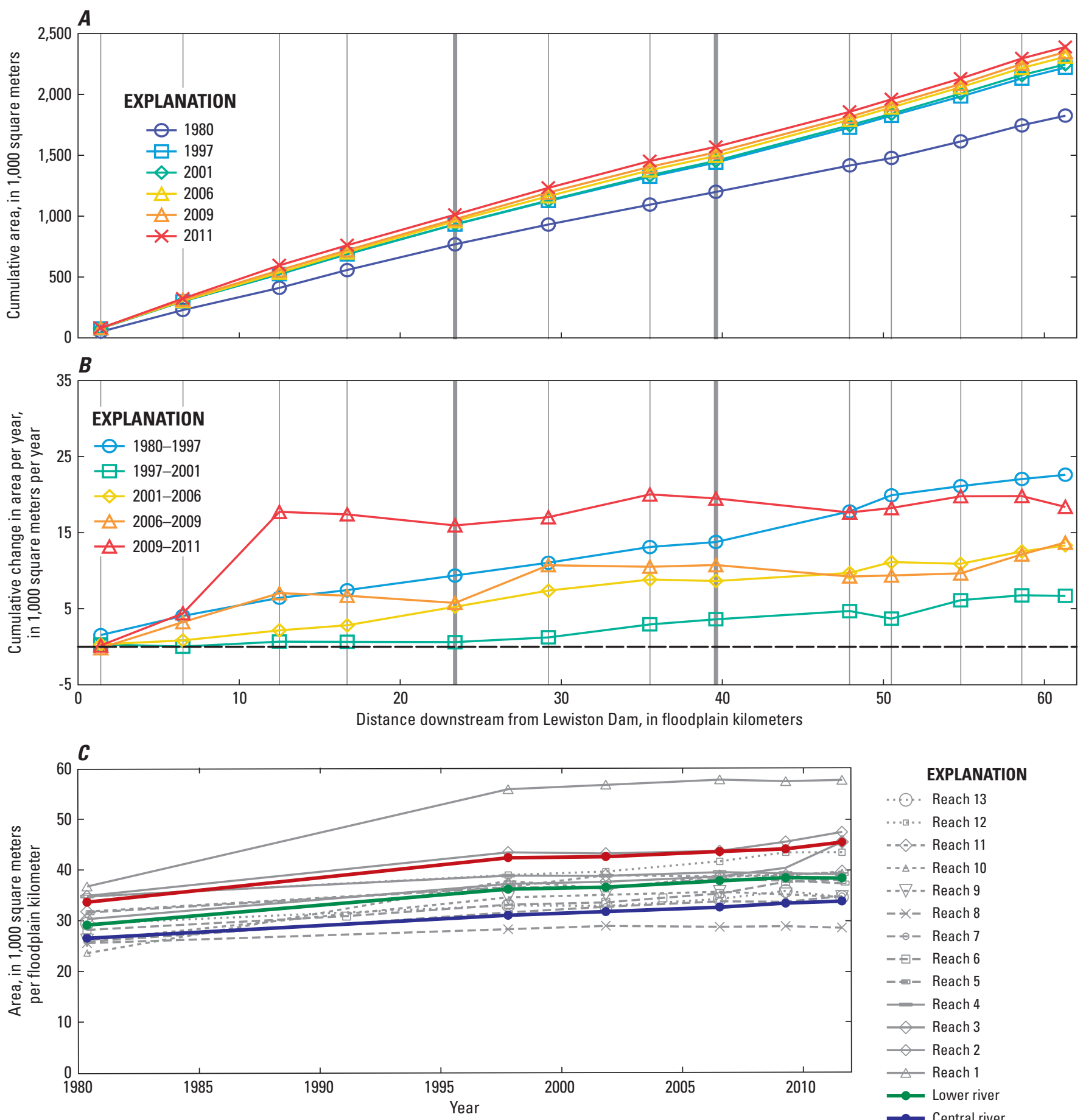

EXPLANATION

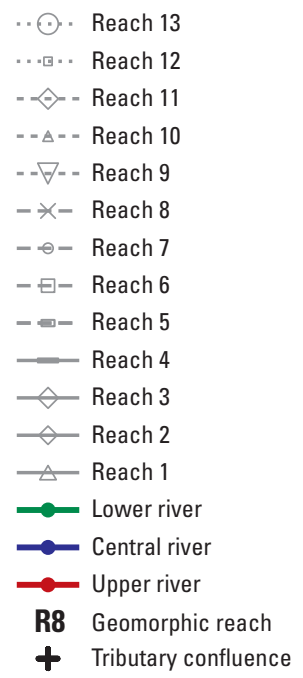

Figure 15. Area of the active channel along the Trinity River downstream from Lewiston Dam, California, and change in active channel area from 1980 to 2011: $A$, cumulative area by study reach; $B$, cumulative change in area per year by study reach; $C$, area by study reach and river segments over time. 


\section{Active bars}

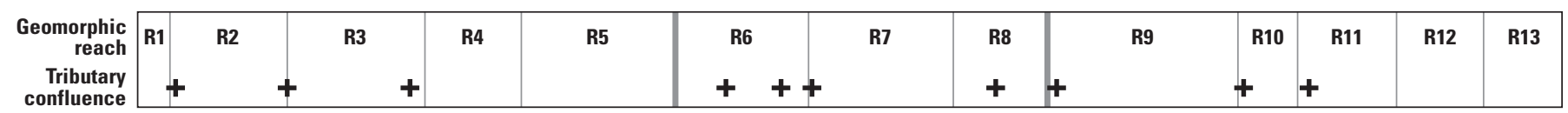
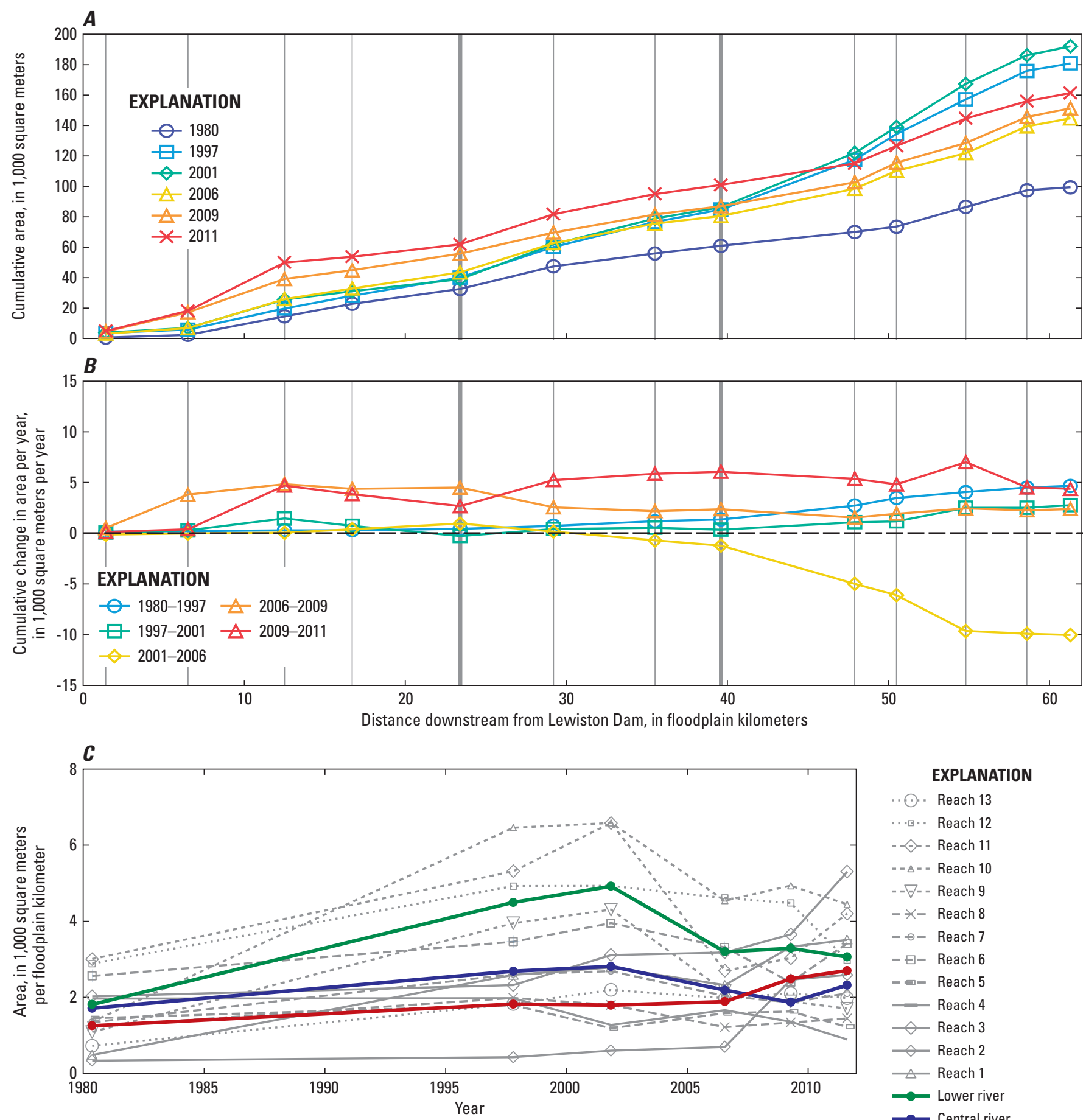

EXPLANATION

\section{..... Reach 13}

.... . Reach 12

$-\diamond-$ Reach 11

$=-\Delta=-$ Reach 10

- - $\nabla-$ - Reach 9

$-*-$ Reach 8

$-\ominus-$ Reach 7

$-\boxminus-$ Reach 6

-- - Reach 5

- Reach 4

$\checkmark$ Reach 3

$\checkmark$ Reach 2

$\triangle$ Reach 1

$\longrightarrow$ Lower river

$\rightarrow$ Central river

Upper rive

R8 Geomorphic reach

+ Tributary confluence

Figure 16. Area of active bars along the Trinity River downstream from Lewiston Dam, California, and change in active bar area from 1980 to 2011: $A$, cumulative area by study reach; $B$, cumulative change in area per year by study reach; $C$, area by study reach and river segments over time. 
Secondary water features

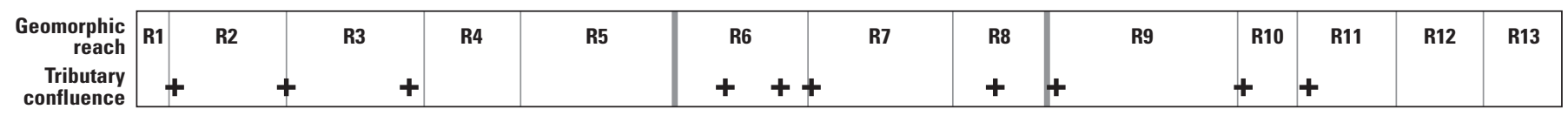
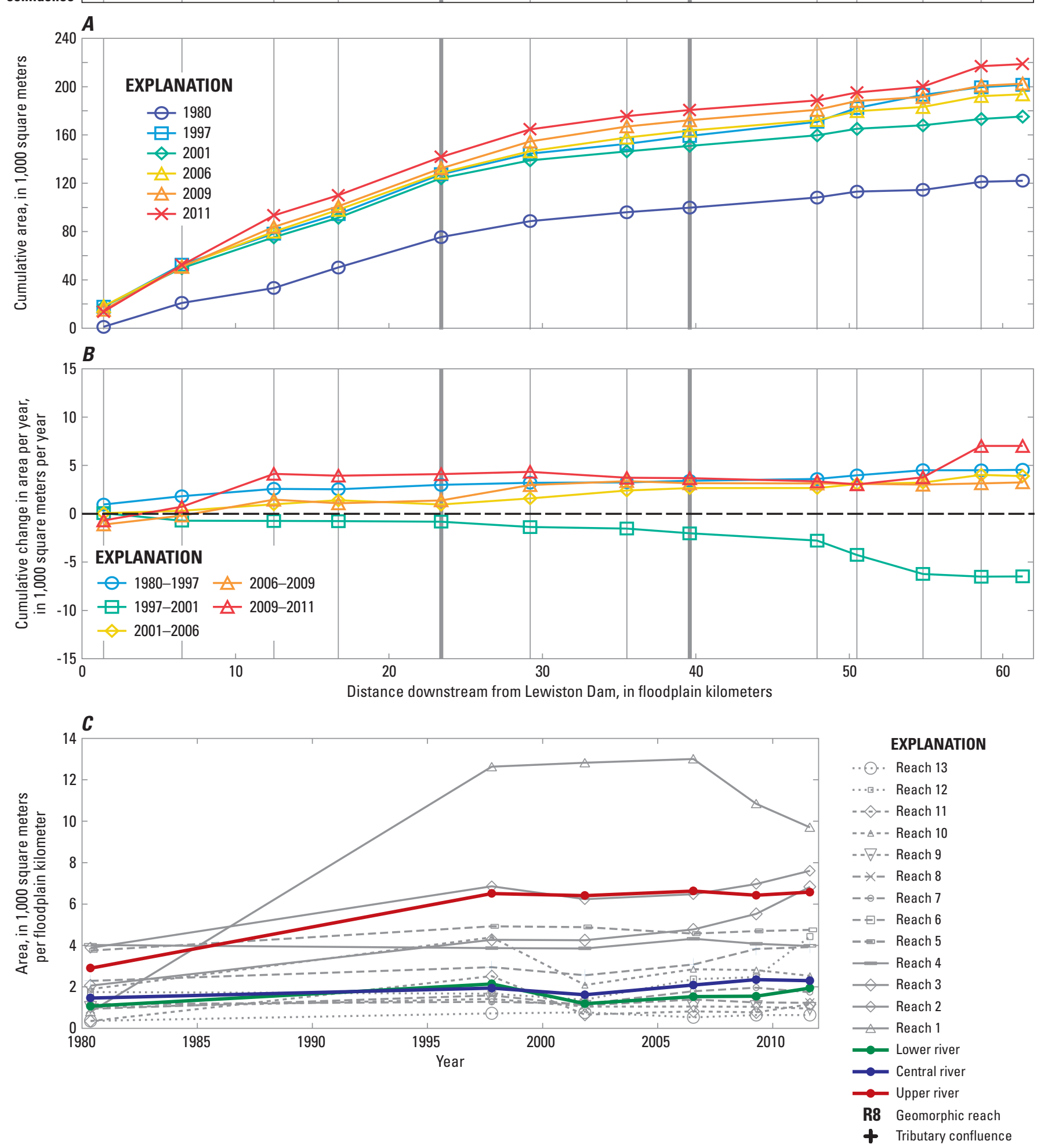

Figure 17. Area of secondary water features (split-flow channels, side channels, alcoves, and aquatic wetlands) along the Trinity River downstream from Lewiston Dam, California, and change in secondary water feature area from 1980 to 2011: $A$, cumulative area by study reach; $B$, cumulative change in area per year by study reach; $C$, area by study reach and river segments over time. 

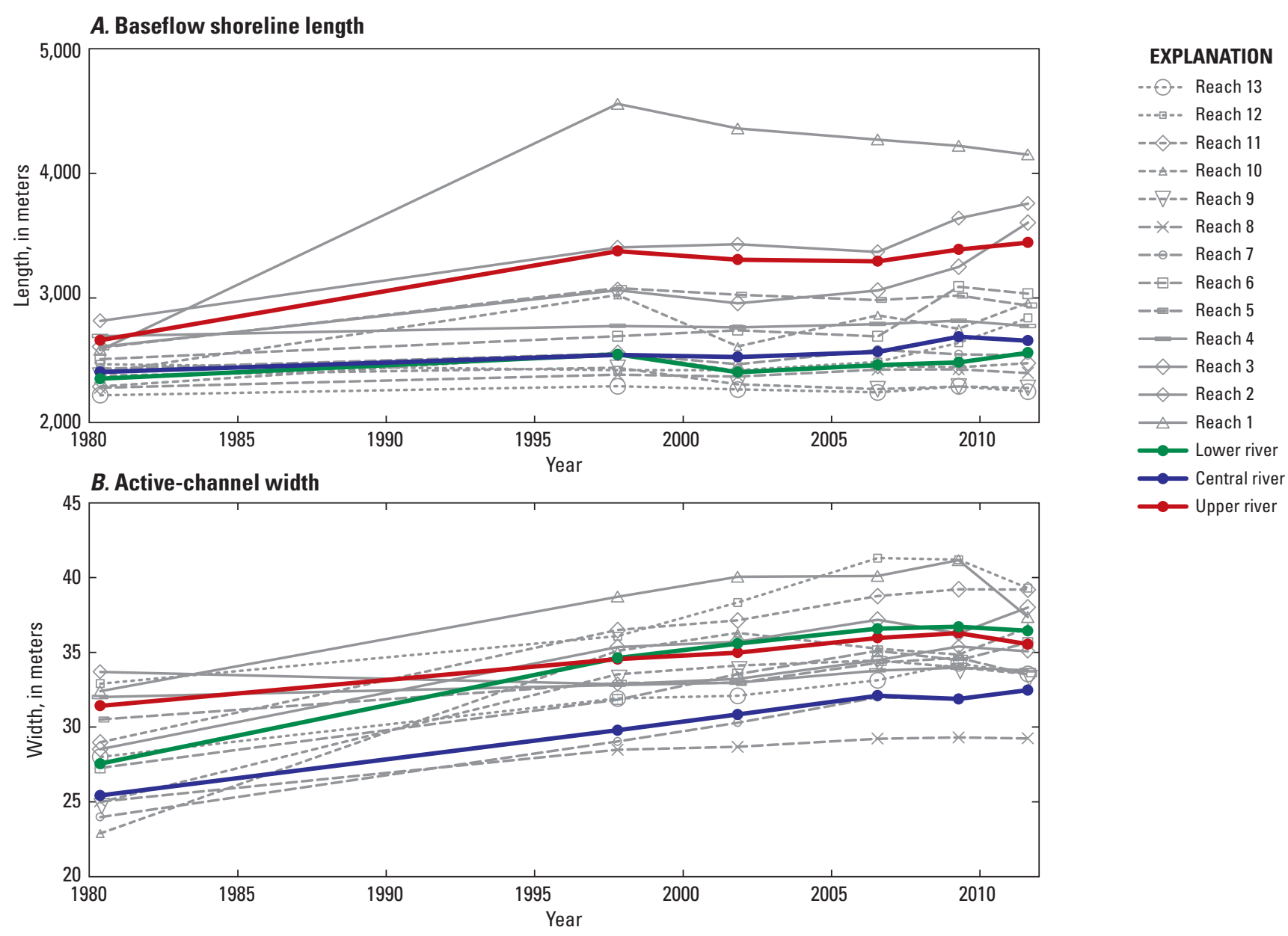

Figure 18. Temporal changes in the active-channel from 1980 to 2011 for the Trinity River downstream from Lewiston Dam, California: $A$, baseflow shoreline length; $B$, active-channel width.

At the upstream end of the lower river segment, the river flows through a wider reach (39.6-47.9 FPkm), where the local sediment supply increases as a result of bank erosion. Continuing downstream (47.9-54.8 FPkm), transport capacity and sediment supply increase again as a result of contributions from bank erosion, Canyon Creek (51.0 FPkm), and, to a lesser extent, Oregon Gulch (48.2 FPkm). Although there are no large local sediment sources at the bottom of the study reach (54.8-61.3 FPkm), upstream sources of flow and sediment maintain dynamic river processes.

\section{Streamflow and Sediment Supply}

To assess transport capacity in greater detail, we analyzed the size, frequency, and duration of flows at five USGS gaging stations along the mainstem Trinity River (fig. 2; table 5). Our analyses necessarily focused on the Lewiston gage, which is approximately $1.5 \mathrm{~km}$ downstream from Lewiston Dam. Flows at the Lewiston gage represented regulated conditions, but this was the only site with continuous daily flow data spanning the study period. The four downstream gages had partial records.
Mean daily flows at the Lewiston gage for the pre- and post-ROD periods were $700 \mathrm{ft}^{3} / \mathrm{s}$ and $890 \mathrm{ft}^{3} / \mathrm{s}$, respectively. Analysis of local precipitation records indicated the increase in mean daily flows was caused by increases in post-ROD annual flow releases rather than increased precipitation. Monthly precipitation records from the National Weather Service station near Weaverville, California, indicated the long-term mean annual precipitation from 1911 to 2011 was $935 \mathrm{~mm}$. Mean annual precipitation during the pre-ROD period $(979 \mathrm{~mm})$ was slightly greater than the long-term average, but the post-ROD mean annual precipitation $(465 \mathrm{~mm})$ was about 50 percent of the long-term average.

Figure 19 presents mean daily flows, annual peaks, and annual average flows for the Lewiston gage. During the relatively wetter pre-ROD period, there were three water years (1983, 1997, and 1998) classified as "extremely wet," and one year (1995) classified as "wet" (table 1). The years 1983 and 1995 bracketed a decade of lower flows from 1985 to 1994. During the relatively drier post-ROD period, one year (2006) was classified as "extremely wet," and two years (2004 and 2011) were classified as "wet." 

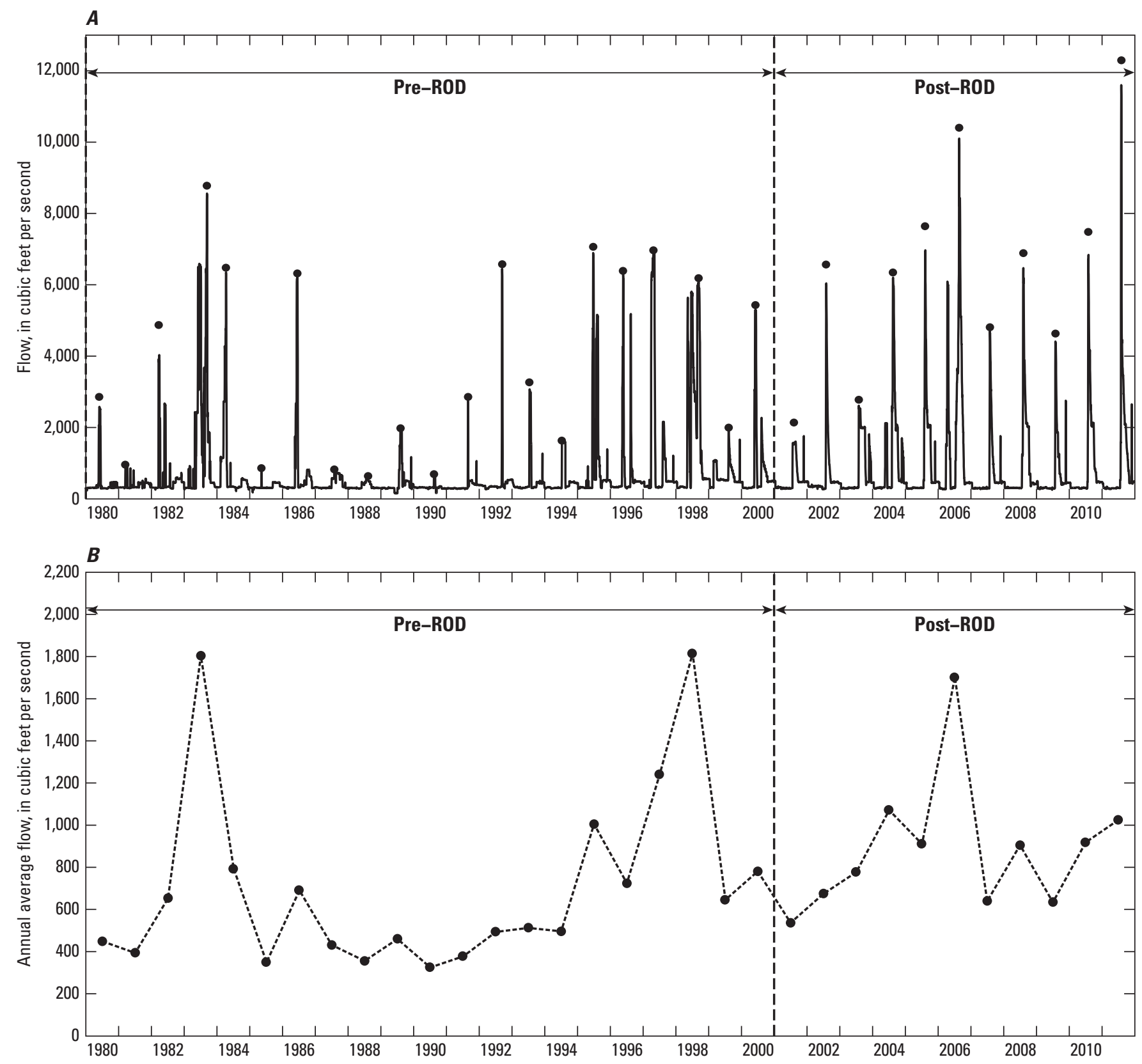

Figure 19. Streamflow measured at the Lewiston gage on the Trinity River, California, $1.5 \mathrm{~km}$ downstream from Lewiston Dam, from 1980 to 2011: $A$, mean daily and annual peak flows; $B$, annual average flows. ROD, Record of Decision. 
The post-ROD flow regime altered the timing and variability of annual peak flows released from Lewiston Dam. Winter peak-flow releases were eliminated, and the peak release was shifted to the spring to mimic snowmelt conditions. Analysis of the monthly distribution of mean daily flows at the Lewiston gage indicated that annual peak-flow releases during the pre-ROD period were distributed from December to June, whereas the post-ROD peak-flow releases were larger in May and June (fig. 20). Notably, post-ROD flows from February to April were lower compared to preROD flows.

Post-ROD flows were also evaluated by computing the number of exceedance days at the Lewiston gage for the prescriptive ROD-flow thresholds (table 1). Mean daily flows greater than $1,500 \mathrm{ft}^{3} / \mathrm{s}$ occurred about three times more frequently during the post-ROD period compared to the pre-ROD-period, whereas the medium-range flow thresholds of 4,500 and $6,000 \mathrm{ft}^{3} / \mathrm{s}$ were exceeded 90 and 60 percent more frequently, respectively, during the post-ROD period. Flows greater than $8,500 \mathrm{ft}^{3} / \mathrm{s}$ were exceeded an average of about 1.7 days per year during the post-ROD period compared to 0.1 days per year during the pre-ROD period.

Tributary flows were important drivers of geomorphic change, particularly during wet periods. Unlike clear-water releases from Lewiston Dam, the amount of sediment delivered to the mainstem study reach from ungaged tributaries is unknown, but likely substantial (Ritter, 1968; Knox, 1974; Trinity River Taskforce, 1979; U.S. Fish and Wildlife Service and Hoopa Valley Tribe, 1999; Graham Matthews and Associates, 2001). The contributing area upstream from Lewiston Dam $\left(1,850 \mathrm{~km}^{2}\right)$ represents 63 percent of the total contributing area upstream from the North Fork Trinity River $\left(2,930 \mathrm{~km}^{2}\right)$. Sediment supply from Grass Valley Creek (11.85 FPkm; fig. 2), which represents 3 percent $\left(94 \mathrm{~km}^{2}\right)$ of the contributing area, is detained by a series of retention ponds so that only 34 percent $\left(986 \mathrm{~km}^{2}\right)$ of the Trinity River watershed contributes bedload to the study reach (fig. 21). The contributing areas for the upper, central, and lower river reaches were 131,550 , and $305 \mathrm{~km}^{2}$, representing 13, 56, and 31 percent, respectively. Indian, Weaver, and Redding Creek all flow into the central river upstream from the Douglas City gage (29.9 FPkm). A recent sediment-budget estimate of the study reach upstream from the Douglas City streamgage determined that the transition between sediment deficit and surplus conditions under present conditions is between the Douglas City and Limekiln Gulch gage (20.4 FPkm; Gaeuman and Krause, 2011), which is upstream from the central river reach's boundary (23.4 FPkm). Based on contributing area, sediment budget estimates, and active bar area, the transition from a sediment deficit to a sediment surplus condition is downstream from Indian Creek (25.6 FPkm).
Inconsistencies in the timing of tributary-flow events and mainstem flushing-flow releases influenced sediment dynamics in the study reach. Precipitation-driven tributary flows and the associated sediment delivery peaked during the winter and spring and did not coincide with the peak-flow releases. Peak-flow releases occurred from May to June, and from 2008 to 2011, these were accompanied by the direct injection of gravel. The delay of peak-flow releases results in interim channel aggradation.

Aggradation of tributary confluences has been a recurring problem (Ritter, 1968; Trinity River Taskforce, 1979; U.S. Fish and Wildlife Service and Hoopa Valley Tribe, 1999) because it produces upstream slackwater conditions on the mainstem, where undesirable fine bed material (less than $8 \mathrm{~mm}$ ) accumulates. Wilcock and others (1995) recommended moderate peak-flow releases $\left(4,500\right.$ to $\left.6,000 \mathrm{ft}^{3} / \mathrm{s}\right)$ to mobilize bed material and remove undesirable fine-grained bed material and higher peak flows $\left(8,500\right.$ to $\left.11,000 \mathrm{ft}^{3} / \mathrm{s}\right)$ to produce deeper scour and greater transport.

The effects of tributary-flow contributions on mainstem transport capacity are illustrated in figure 22, which shows mean annual flows for the five mainstem gages from 1996 to 2011, the period in which multiple mainstem gages were in operation (table 5). During the relatively wetter 2006 and 2011 water years, mean annual flow at the North Fork gage was 70 to 80 percent greater than at the Lewiston gage. Again, we inferred, on the basis of previous investigations, that these tributary-flow events contributed large, but unknown, amounts of sediment.

Figure 23 illustrates mean daily flows for mainstem gages and highlights two pre-ROD water years $(1997,1998)$ and two post-ROD years $(2006,2011)$, which represent the four largest tributary-flow events during the study period. The influence of tributaries on mainstem flows was clear in December 1997, when mean daily flows increased from about $6,900 \mathrm{ft}^{3} / \mathrm{s}$ at Lewiston to $10,200 \mathrm{ft}^{3} / \mathrm{s}$ at Douglas City and to 27,000 $\mathrm{ft}^{3} / \mathrm{s}$ at Junction City. In February 1998, mean daily flows increased from about 5,600 $\mathrm{ft}^{3} / \mathrm{s}$ at Lewiston to $9,900 \mathrm{ft}^{3} / \mathrm{s}$ at Douglas City and to $25,000 \mathrm{ft}^{3} / \mathrm{s}$ at Junction City. Mean daily flows released in December of 2006 were about $1,500 \mathrm{ft}^{3} / \mathrm{s}$ at Lewiston, but increased to 7,500 $\mathrm{ft}^{3} / \mathrm{s}$ at Douglas City, to $12,000 \mathrm{ft}^{3} / \mathrm{s}$ at Junction City, and to nearly $20,000 \mathrm{ft}^{3} / \mathrm{s}$ at the North Fork gage (fig.23D). In comparison, mean daily flows in May 2011, during the largest flow release since 1974 (Krause, 2012a), lacked tributary contributions because the flow release did not coincide with tributary runoff. In May 2011, flow releases at Lewiston peaked at $12,000 \mathrm{ft}^{3} / \mathrm{s}$, compared to $12,500 \mathrm{ft}^{3} / \mathrm{s}$ at Limekiln Gulch, 12,900 $\mathrm{ft}^{3} / \mathrm{s}$ at Douglas City, $13,700 \mathrm{ft}^{3} / \mathrm{s}$ at Junction City, and $12,900 \mathrm{ft}^{3} / \mathrm{s}$ at the North Fork gage (fig.23E). 


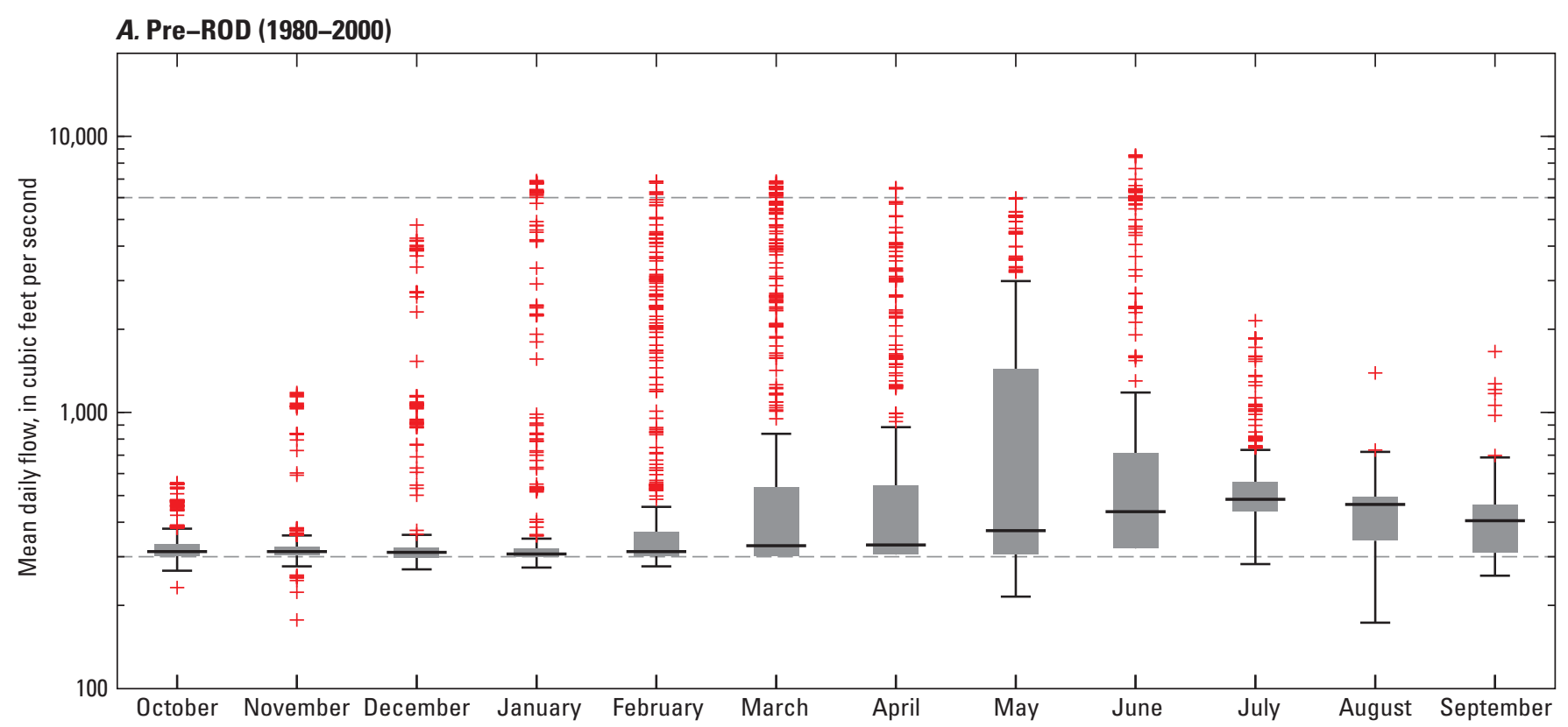

B. Post-ROD (2001-2011)

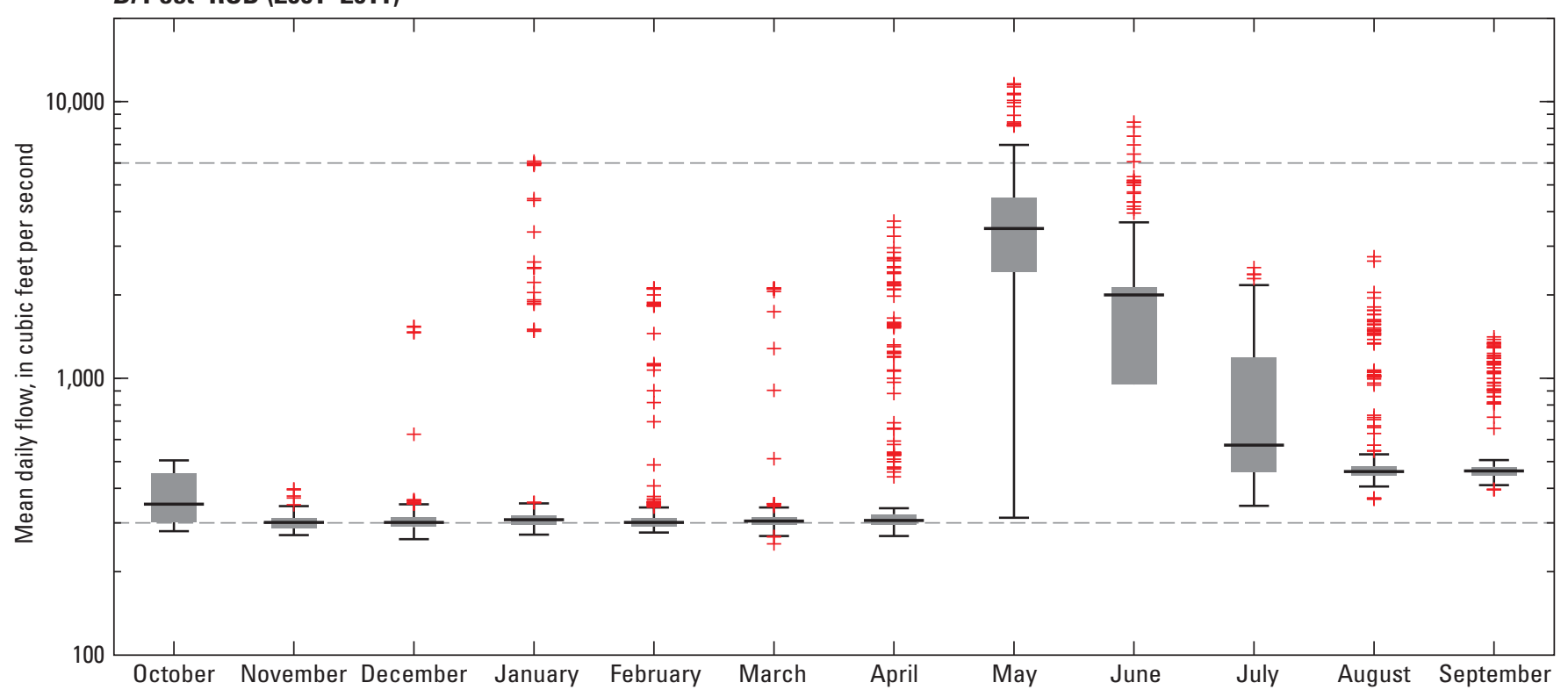

Figure 20. Mean daily flows from 1980 to 2011, grouped by month with minimum in-stream flow, for the Lewiston gage on the Trinity River, California: $A$, pre-ROD (Record of Decision) period; $B$, post-ROD period. The horizontal dashed lines indicate 300 cubic feet per second, which represents summer-baseflow conditions, and 6,000 cubic feet per second, which represents the post-ROD mean annual peak flow. 
Results

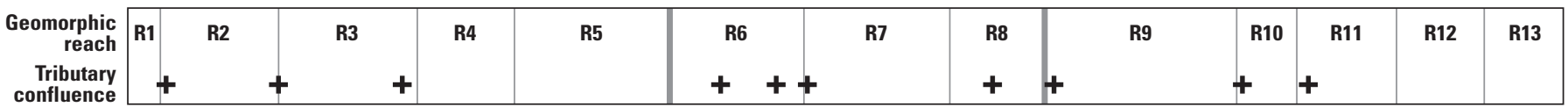

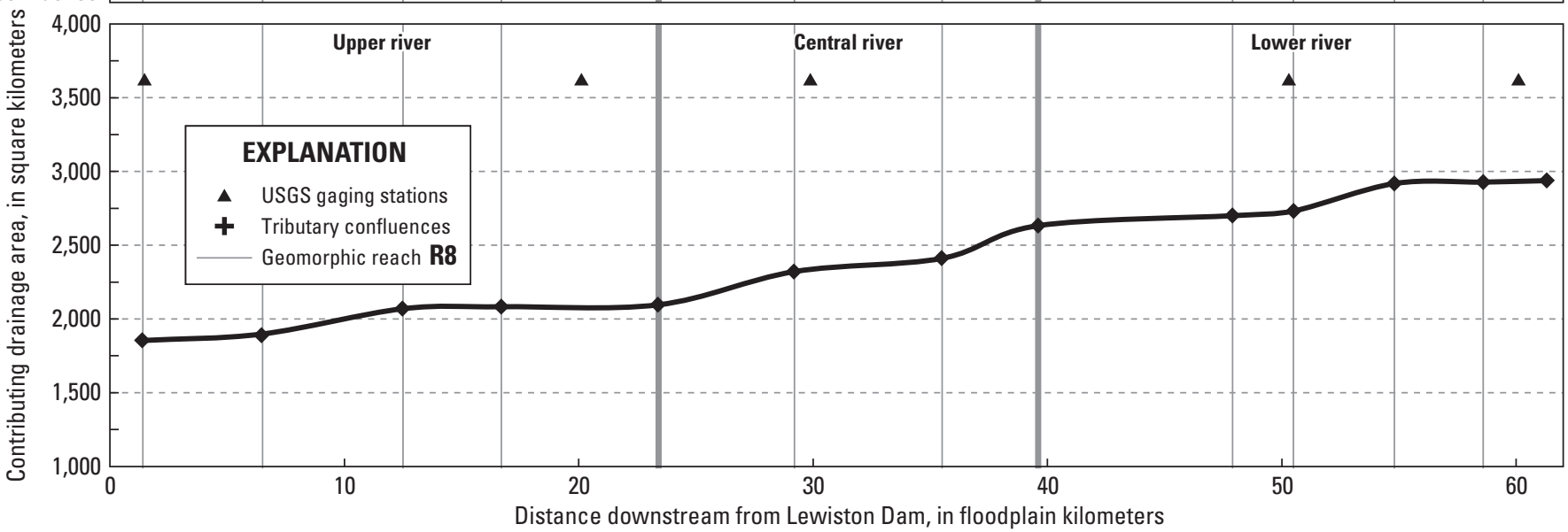

Figure 21. Contributing drainage area for 13 geomorphic reaches, delineated by vertical lines and described in table 2 , along the Trinity River downstream from Lewiston Dam, California. USGS, U.S. Geological Survey.

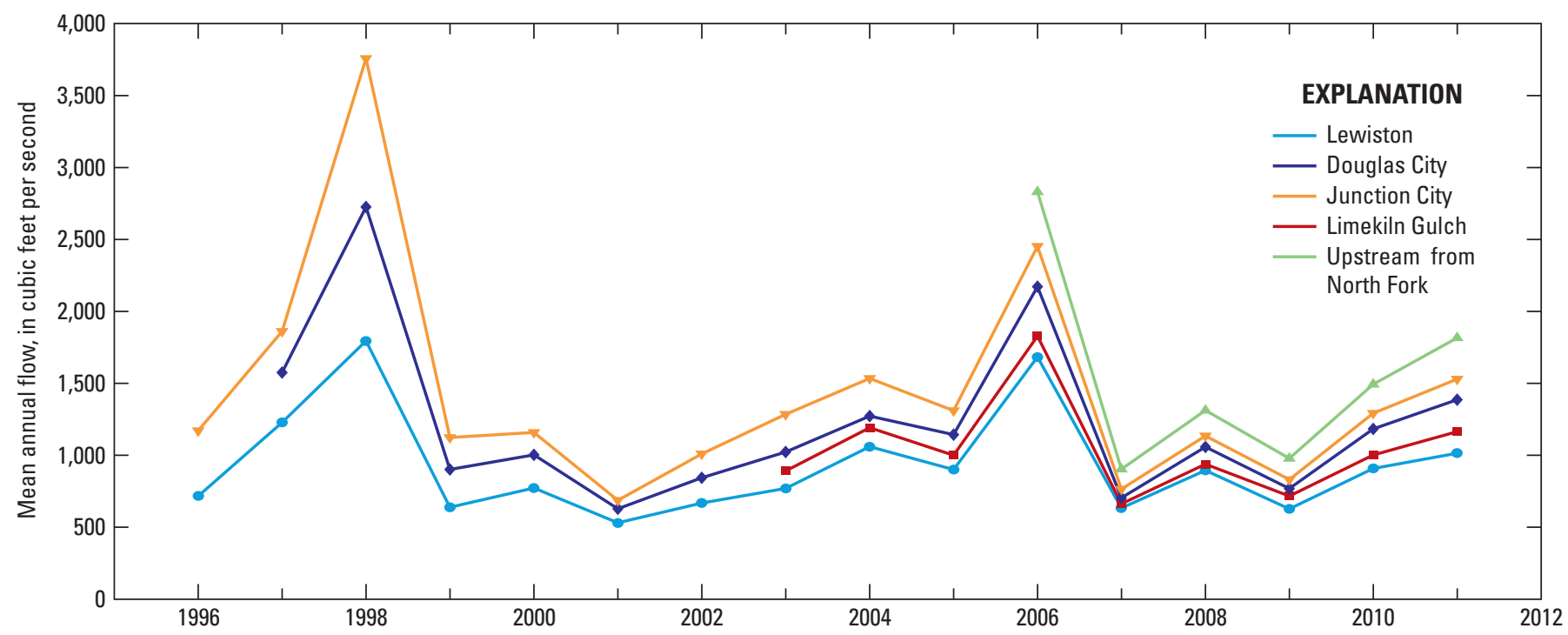

Figure 22. Mean annual flow measured at five mainstem gages on the Trinity River, California, downstream of Lewiston Dam, California, from 1996 to 2011. 

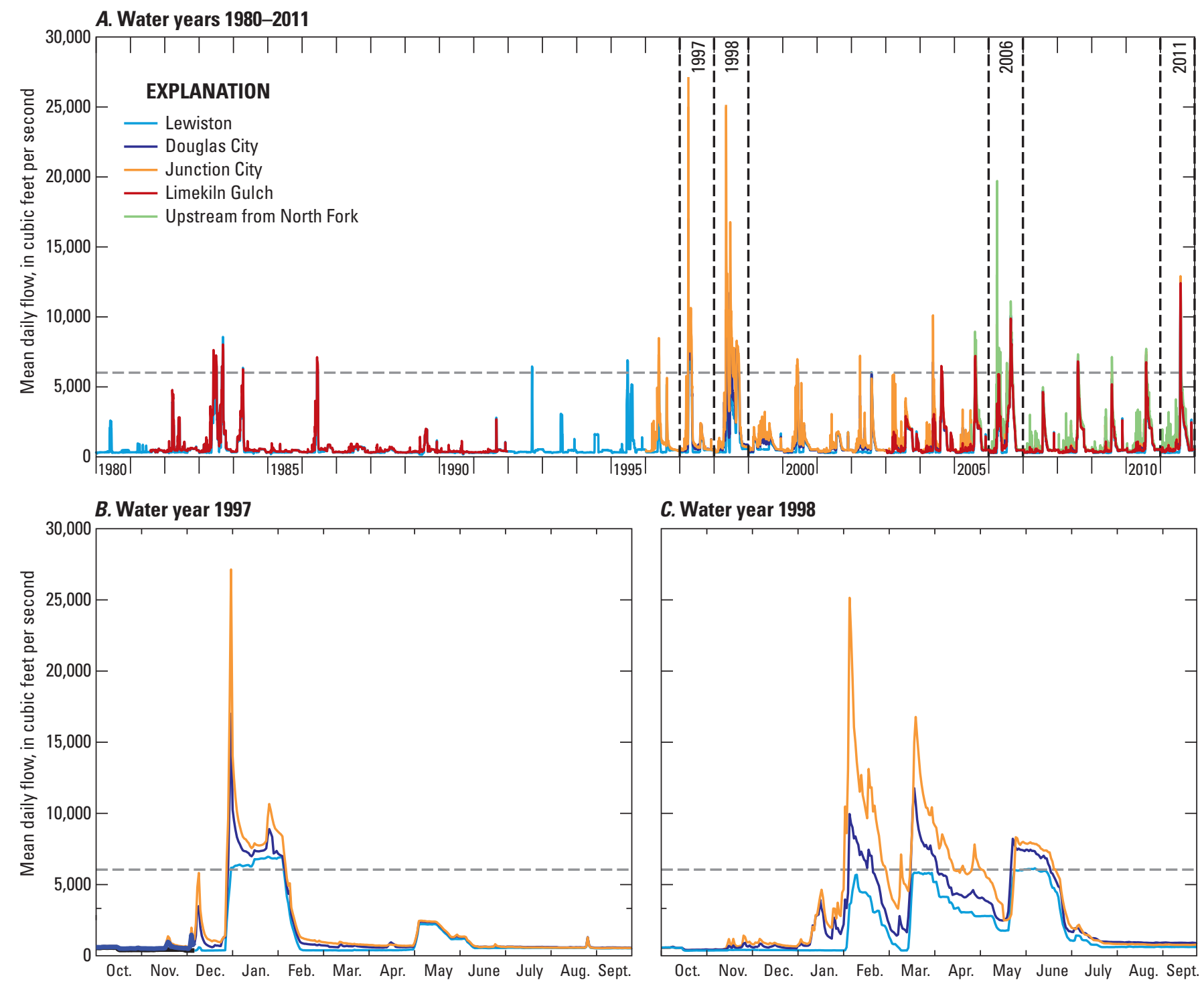

\section{Water year 1998}
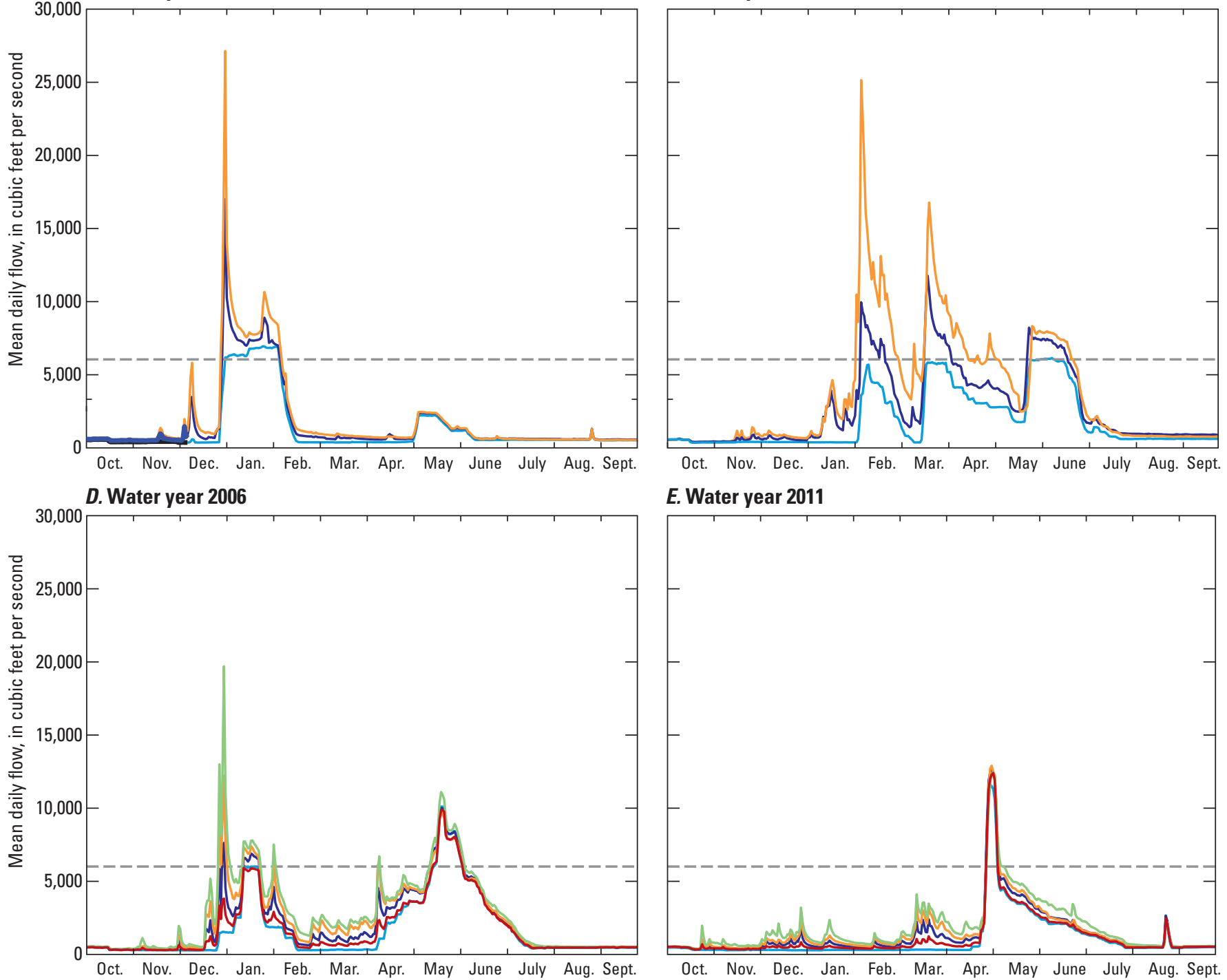

E. Water year 2011

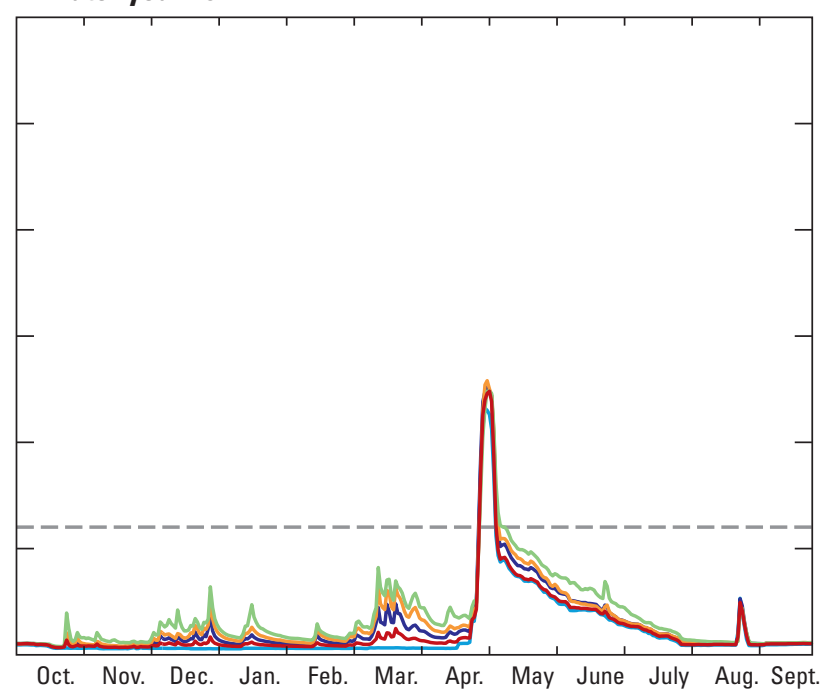

Figure 23. Mean daily flows measured at five mainstem gaging stations on the Trinity River, California, downstream from Lewiston Dam, from 1980 to 2011, and annual time series for four wettest years during the study period: $A, 1997 ; B, 1998$; $C, 2006 ; D, 2011$. Dashed horizontal line denotes 6,000 cubic feet per second, which represents the post-Record of Decision mean annual peak flow. 


\section{Sediment Management and Mechanical Channel Rehabilitation}

The history of sediment management and mechanical channel rehabilitation were reviewed earlier in this report, and in this section we present pertinent details. Figure 24 provides a spatial and temporal summary of management actions in the project reach. Pre-ROD management was focused on restoring adult-holding and spawning habitat (Trinity River Taskforce, 1970). Adult salmonids require deep-water holding pools and spawning riffles free of fine bed material (less than $8 \mathrm{~mm}$ ). Pre-ROD dredging of mainstem pools increased and maintained deep-water adult-holding habitat. Riffle and grade-control construction created spawning habitat, whereas upland watershed restoration and sediment-retention basins at the Grass Valley Creek confluence reduced the delivery of undesirable fine-sediment (U.S. Bureau of Land Management, 1995; Graham Matthews and Associates, 2001).

Krause (2012a) provided a detailed history of sediment extraction and augmentation for the study reach, which is summarized in figure 25. Following dam closure, flow diversions, combined with elevated tributary sediment supply related to land use, caused significant aggradation of the channel bed with sand-sized bed material that filled pools and inundated spawning areas (U.S. Fish and Wildlife Service and Hoopa Valley Tribe, 1999). Sediment extraction, primarily by pool dredging, and to a lesser degree bar scalping, began in 1976 and continued until 1990. Extracted volumes of sediment were composed of approximately 15-25 percent coarse-grained sediment (greater than 16-mm in diameter) and about 75-85 percent finer grained material (less than $16 \mathrm{~mm}$ ).

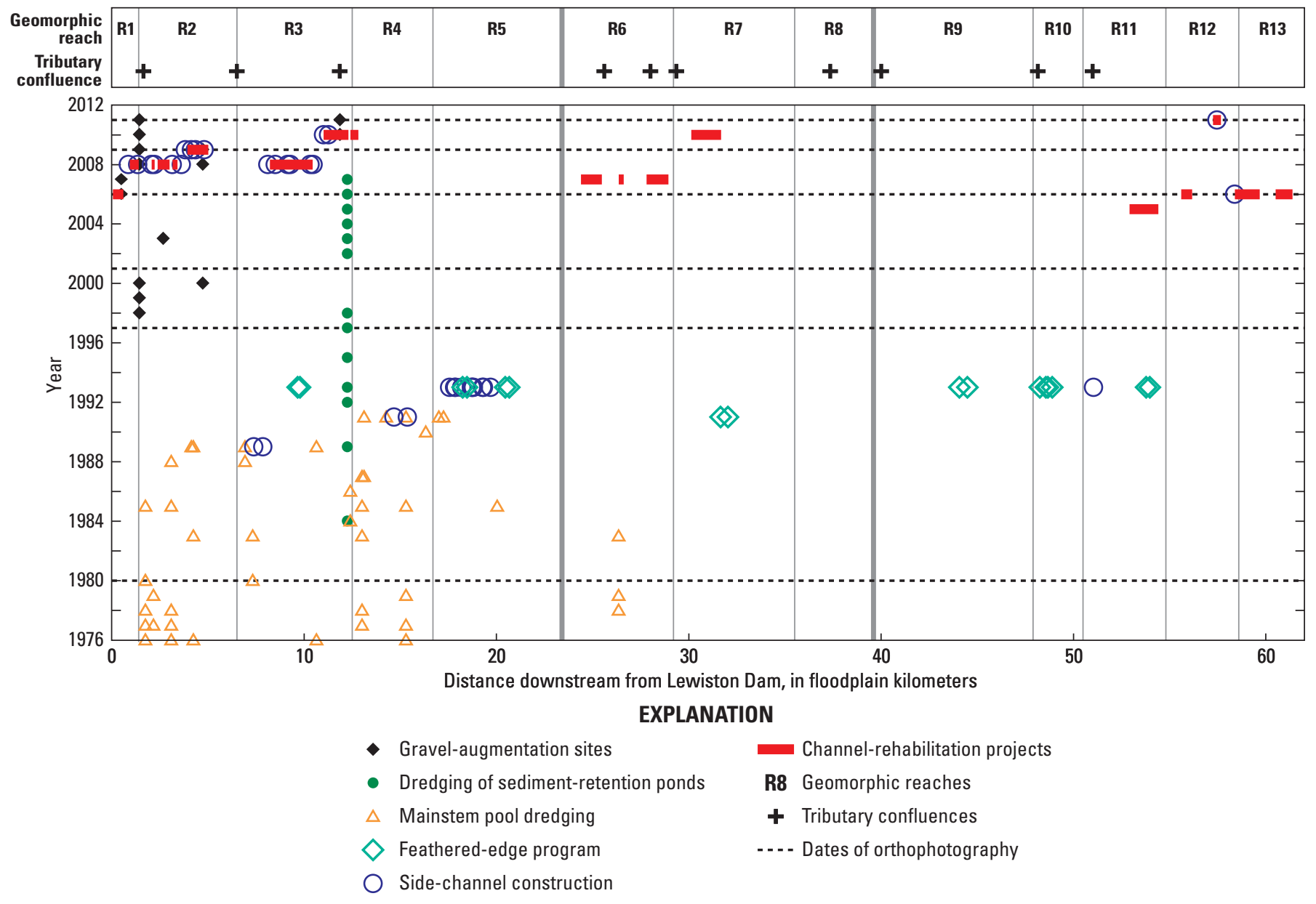

Figure 24. Summary of relevant management actions from 1976 to 2011 along the Trinity River downstream from Lewiston Dam, California. 


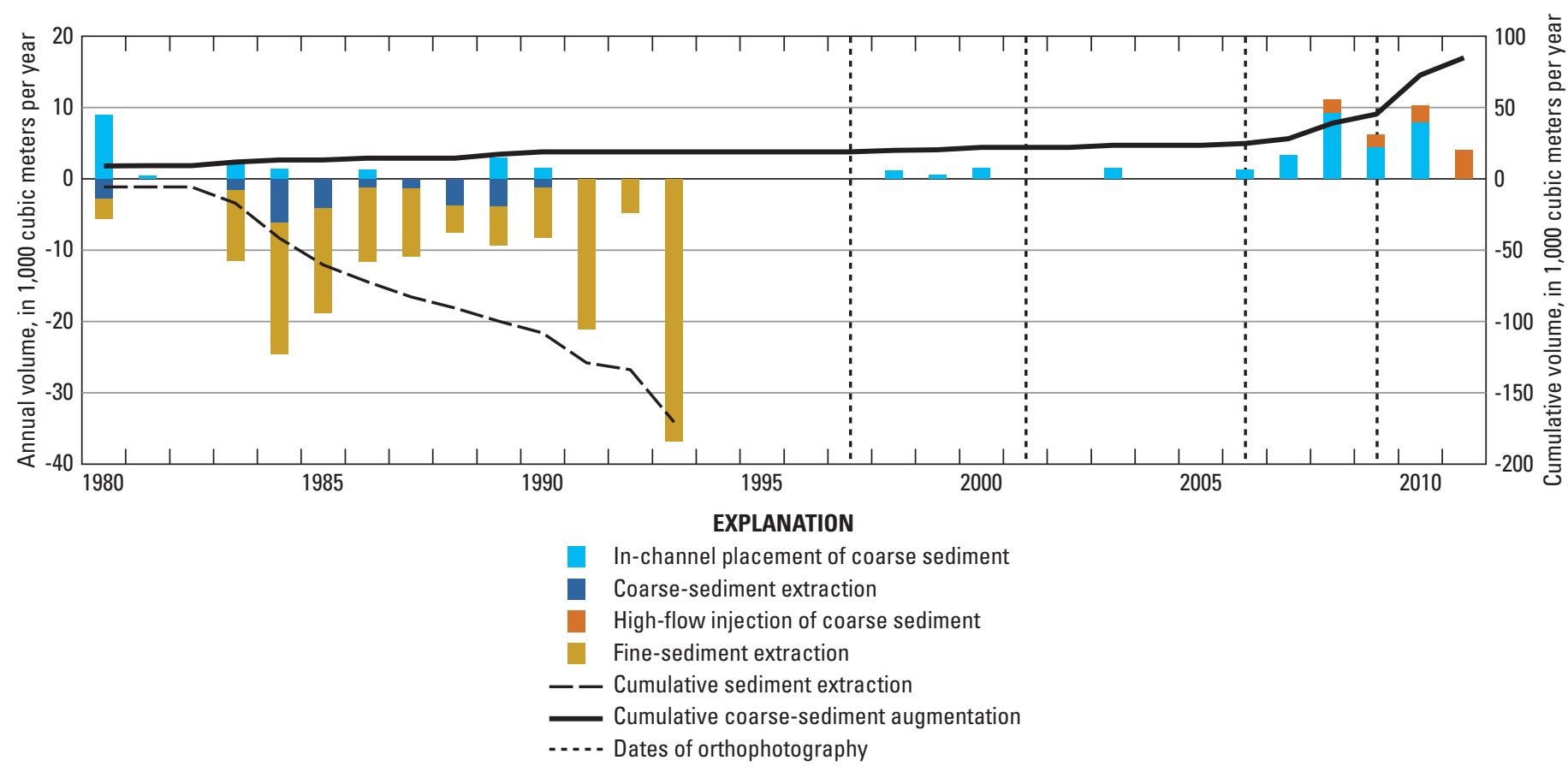

Figure 25. Annual and cumulative volumes of sediment extraction and augmentation for Trinity River downstream from Lewiston Dam, California, from 1980 to 2011 (Krause, 2012b).

A summary of constructed features is presented in figure 26. An emphasis on salmonid rearing habitat began in the 1990s (U.S. Fish and Wildlife Service, 1989), and a series of 18 side channels and 9 bank-rehabilitation projects, referred to as "feathered edges," were constructed to create shallow-water rearing habitat (fig. 24; U.S. Fish and Wildlife Service, 1994). Side-channel construction increased shoreline length and low-velocity off-channel rearing habitat and also created large island features. The "feathered edge" program targeted overly steep channel margins where vegetation had encroached. Riparian vegetation and sediment berms were mechanically removed to create gently sloping, gravelly channel margins intended to function as mainstem rearing habitat.

In 1999, the TRFE determined the lack of rearing habitat continued to be a primary limiting factor for sustainable salmonid populations and made recommendations for prescriptive-flow management, channel rehabilitation, and augmentation of coarse bed-material-sized sediment adopted by the ROD in 2001. The TRFE identified 44 potential channel-rehabilitation sites and 3 potential side-channel sites. Construction of these projects began in 2005 under a phased approach to allow for monitoring and performance assessment (Trinity River Restoration Program and ESSA Technologies Ltd., 2009). From 2005 to 2011, 19 of the proposed rehabilitation projects were constructed (fig. 24).

The design of post-ROD channel-rehabilitation projects evolved over time. Early designs, constructed in 2005 and 2006, were relatively simple channel-floodplain connectivity projects designed to facilitate inundation of channel margins by vegetation removal, riparian berm recontouring, and surface lowering of riparian features. These early projects were in the lower river, where ample in-channel and tributary sediment sources existed and where TRRP partners hypothesized the river would "rehabilitate itself." A lack of geomorphic response at these early restoration sites (Hoopa Valley Tribe and others, 2011b) led to broader hypotheses and the evolution of project designs. More recent projects, constructed from 2006 to 2011, focused on enhancing channel-floodplain connectivity and utilized new design criteria (Hoopa Valley Tribe and others, 2011a) to mechanically increase the diversity and extent of salmonid habitat by incorporating channel complexity features into project designs.

Gravel augmentation to create and maintain spawning habitat in the upper river began in 1972 and continued into the post-ROD period. Gravel augmentation approaches evolved from the pre-ROD strategy of in-channel placement of static gravel features to provide spawning or rearing habitat to the post-ROD strategy of direct injection during the spring peak-flow release (Kondolf and Minear, 2004). In-channel placement of gravel to increase sediment supply and restore dynamic fluvial processes began in 1998. Direct injection during managed high-flow releases, by using front-end loaders or conveyor belts, began in 2008. Although the TRFE recommended gravel augmentation up to 51,000 cubic meters per year $\left(\mathrm{m}^{3} / \mathrm{yr}\right)$, the actual volumes placed each water year varied (fig. 25). At time of writing, recommendations for average annual-injection volumes, based on gravel transport rates and desired bed-surface textures, were about 5,400 $\mathrm{m}^{3} / \mathrm{yr}$ (Gaeuman, 2008). 
A. 1980
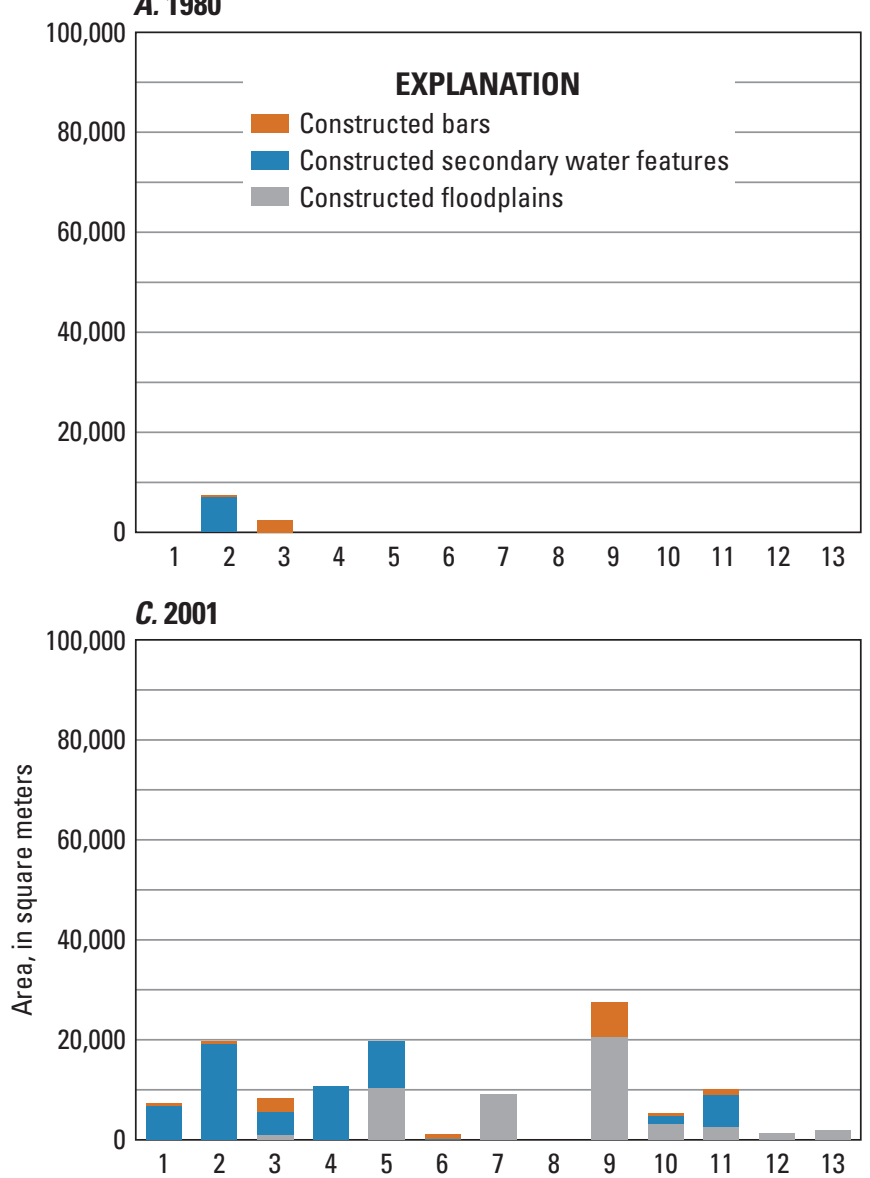

E. 2009

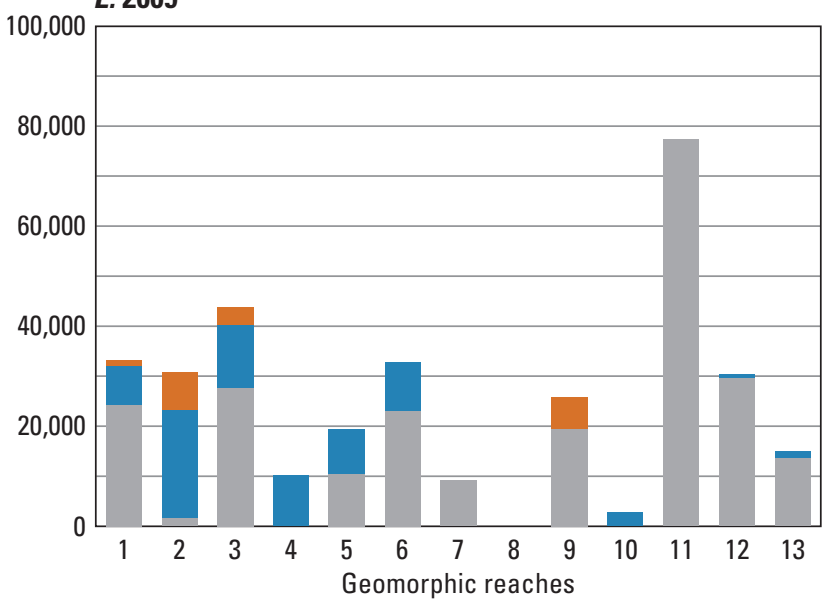

B. 1997
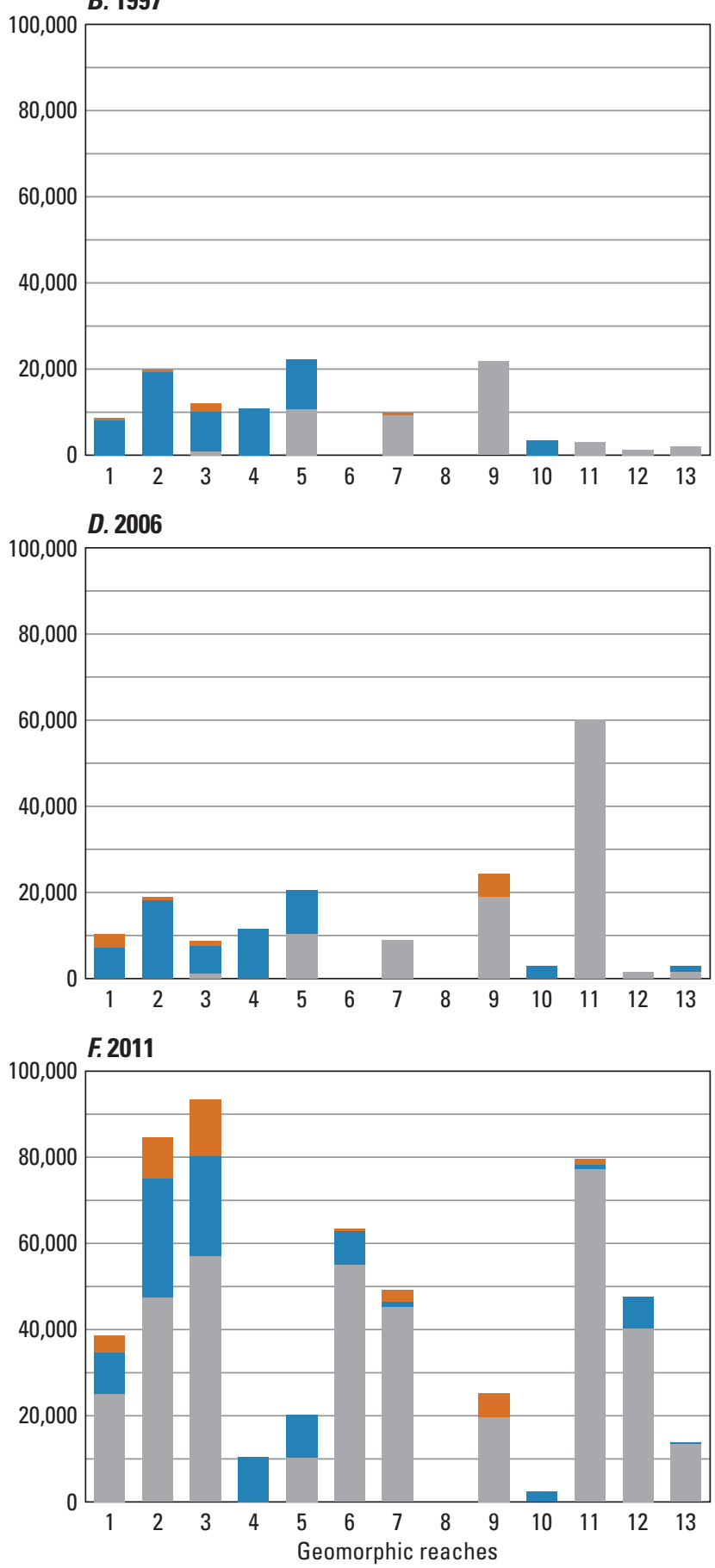

Figure 26. Bar graphs showing a summary of constructed riparian and channel features along the Trinity River downstream from Lewiston Dam, California, in 1980, 1997, 2001, 2006, 2009, and 2011. 


\section{Assessing Geomorphic Change along the Trinity River Downstream from Lewiston Dam, California, 1980 to 2011}

\section{Summary of Bar and Bank Processes}

Lateral changes induced by bar and bank processes were characterized by summarizing change polygons in 1-km subreaches during the five periods of interest. We used conditional statements, as described previously, in a geographic information system (GIS) to estimate scour and accretion by quantifying changes in bar and bank spatial extents.

The first mapping interval, from 1980 to 1997, was dominated by channel widening; 24 percent of the active-channel area showed lateral bank changes compared to about 8 to 10 percent during subsequent periods (table 6). About 7 percent of the active channel showed a change in bar area compared to about 2 to 5 percent during subsequent periods. The combined effects of scour-inducing tributary floods, experimental flow releases, and "feathered-edge" construction resulted in the greatest bank-erosion rates of the study period (fig. 27). There was a small amount of bar accretion, primarily in the vicinity of tributary confluences (fig. 28), and in the lower river, there was scour of bar vegetation (fig. 29). A post-flood assessment (McBain and Trush, Inc., 2000) indicated much of the bank erosion during this period was caused by the 1997 tributary flood (fig. 23), and from 1980 to 1997, mean daily flows at the Lewiston gage exceeded $6,000 \mathrm{ft}^{3} / \mathrm{s}$, the flow threshold designed to mobilize and scour channel features (table 1), for a total of 81 days. Additional management actions that contributed to bank and bar changes included pool dredging and side-channel construction (fig. 24).

The period from 1997 to 2001 was dominated by bar accretion (fig. 28) near Rush Creek (6.5 FPkm), Indian Creek (25.6 FPkm), and downstream from Oregon Gulch (50.5 FPkm). Bank erosion continued (fig. 27), although rates declined slightly (table 6), and bar stabilization by vegetation encroachment ensued throughout the study area (fig. 29). Compared to the previous period, a smaller proportion of the channel underwent bar and bank changes. About 4 percent of the active channel underwent bar scour or accretion, whereas about 10 percent underwent bank erosion or accretion (table 6). The rate of bar accretion was an order of magnitude higher $\left(8,709 \mathrm{~m}^{2} / \mathrm{yr}\right)$ than during the previous period $\left(772 \mathrm{~m}^{2} / \mathrm{yr}\right)$, but the bank erosion rate $(0.24 \mathrm{~m} / \mathrm{yr})$ was similar to the previous period $(0.3 \mathrm{~m} / \mathrm{yr})$. Although there was a large, long duration, tributary-flow event in 1998 (fig. 23), mean daily flows at the Lewiston gage exceeded $6,000 \mathrm{ft}^{3} / \mathrm{s}$ for only 9 days. Management actions were confined to the upper river and included dredging of sediment-retention ponds (fig. 24) and small amounts of gravel augmentation (fig. 25).

Table 6. Summary of bar and bank changes during five study periods for the Trinity River, California, downstream from Lewiston Dam.

[Abbreviations: $\mathrm{m} / \mathrm{yr}$, meter per year; $\mathrm{m}^{2} / \mathrm{m}$, square meter per meter; $\mathrm{m}^{2} / \mathrm{yr}$, square meter per year]

\begin{tabular}{|c|c|c|c|c|c|}
\hline Type of change & 1980 to 1997 & 1997 to 2001 & 2001 to 2006 & 2006 to 2009 & 2009 to 2011 \\
\hline \multicolumn{6}{|c|}{ Bar change } \\
\hline Net change in active-bar area per unit channel length ${ }^{1}\left(\mathrm{~m}^{2} / \mathrm{m}\right)$ & 0.20 & 0.54 & -0.72 & 0.15 & 0.20 \\
\hline Active-channel area experiencing bar scour or accretion (percent) & 7.4 & 3.5 & 5.1 & 2.4 & 4.2 \\
\hline \multicolumn{6}{|l|}{$\begin{array}{ll} & \text { Bank change }\end{array}$} \\
\hline Net change in active-channel area per unit channel length ${ }^{2}\left(\mathrm{~m}^{2} / \mathrm{m}\right)$ & 5.05 & 0.95 & 1.13 & 0.25 & 0.53 \\
\hline
\end{tabular}

${ }^{1}$ Positive values indicate bar accretion, and negative values indicate bar scour. Data normalized by channel length estimated by using the centerline of baseflow channel.

${ }^{2}$ Positive values indicate channel widening and bank erosion, and negative values indicate channel narrowing and bank accretion and riparian vegetation encroachment. Data normalized by channel length estimated by using the centerline of baseflow channel. 


\begin{tabular}{r|r|r|l|l|l|l|l|l|l|l|l|l|l|l|}
$\begin{array}{r}\text { Geomorphic } \\
\text { reach } \\
\begin{array}{r}\text { Tributary } \\
\text { confluence }\end{array}\end{array}$ & R1 & R3 & R4 & R5 & R6 & R7 & R8 & R9 & R10 & R11 & R12 & R13 \\
\hline
\end{tabular}
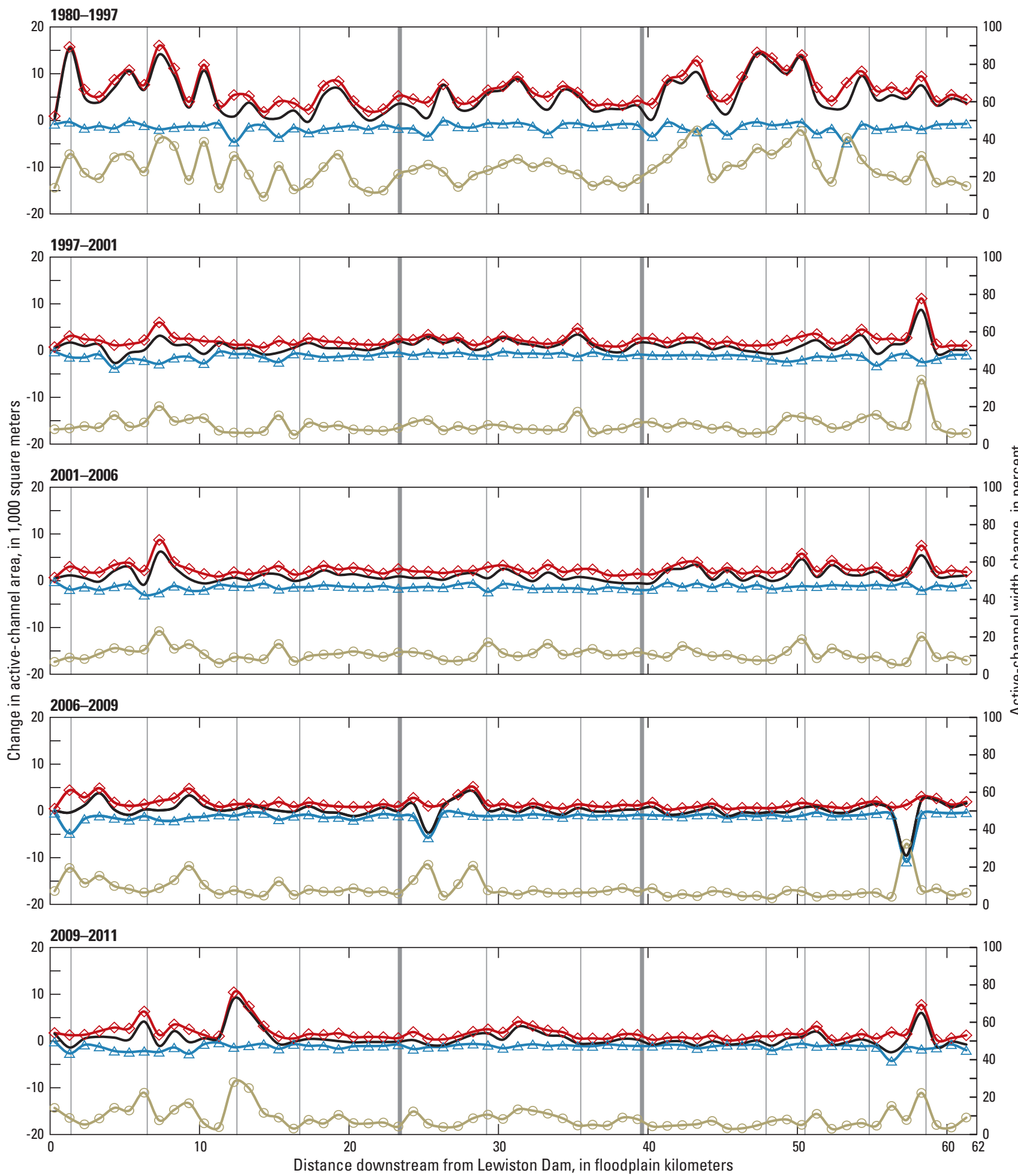

EXPLANATION

$\begin{array}{llc}\triangle \text { Lateral bank accretion (channel narrowing) } & \text { Net change in active-channel area } & \text { R8 Geomorphic reach } \\ \sim \text { Bank erosion (channel widening) } & \sim \text { Change in active channel as percentage of active channel } & +\quad \text { Tributary confluence }\end{array}$

Figure 27. Changes in active-channel area due to bank erosion and accretion along the Trinity River downstream from Lewiston Dam, California, for five periods ending in 1997, 2001, 2006, 2009, and 2011. 


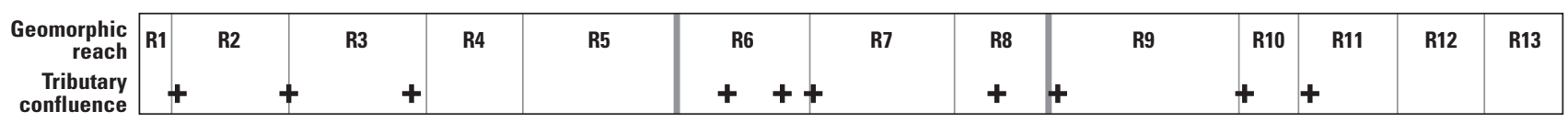
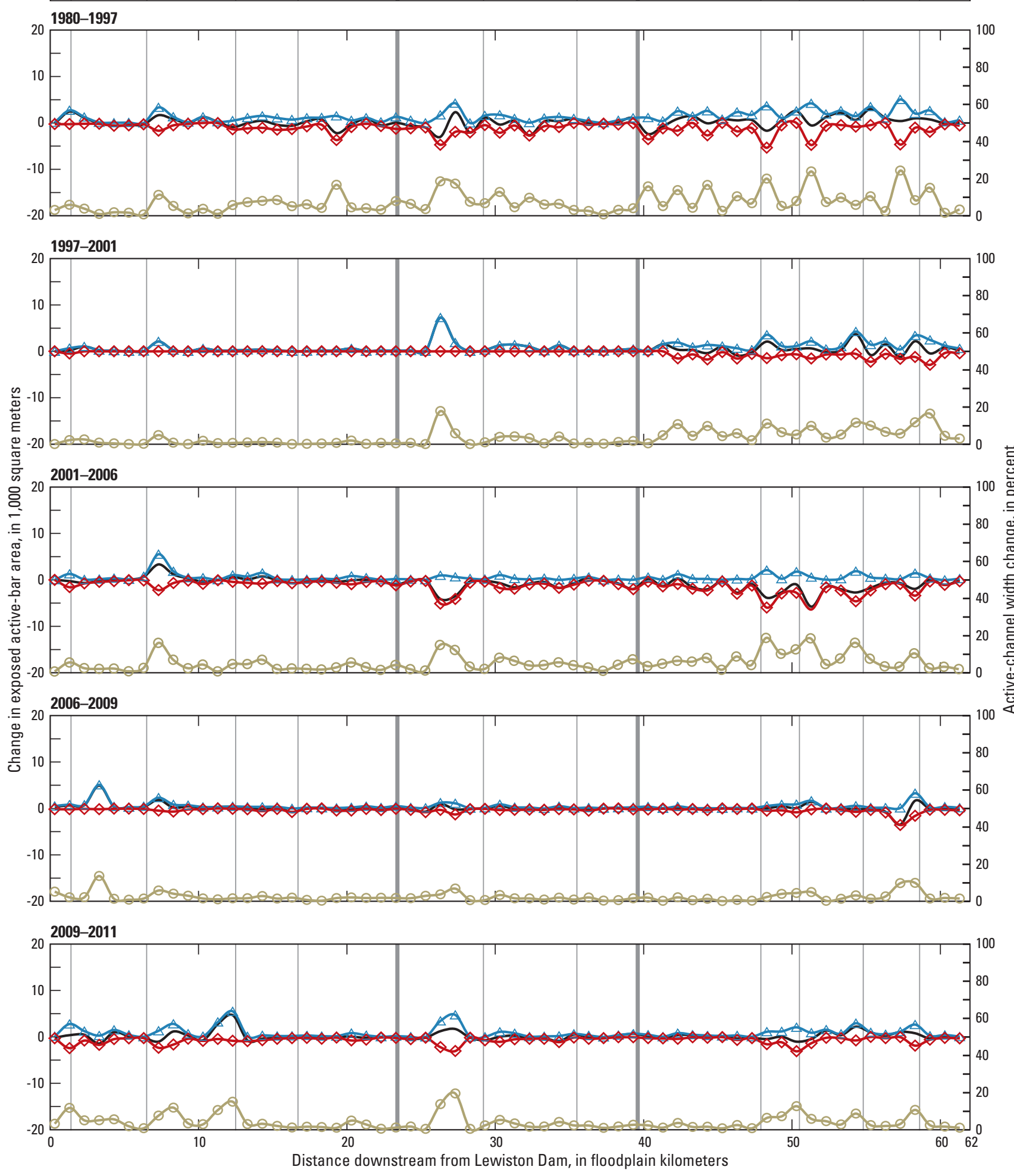

EXPLANATION

$\begin{array}{lll}\triangle \text { Bar accretion } & - \text { Net change in exposed active bar area } & \text { R8 Geomorphic reach } \\ \smile \text { Bar scour } & \smile \text { Change in bar area as percentage of active channel } & + \text { Tributary confluence }\end{array}$

Figure 28. Changes in active-bar area due to bar scour and accretion along the Trinity River downstream from Lewiston Dam, California, for five periods ending in 1997, 2001, 2006, 2009, and 2011. 

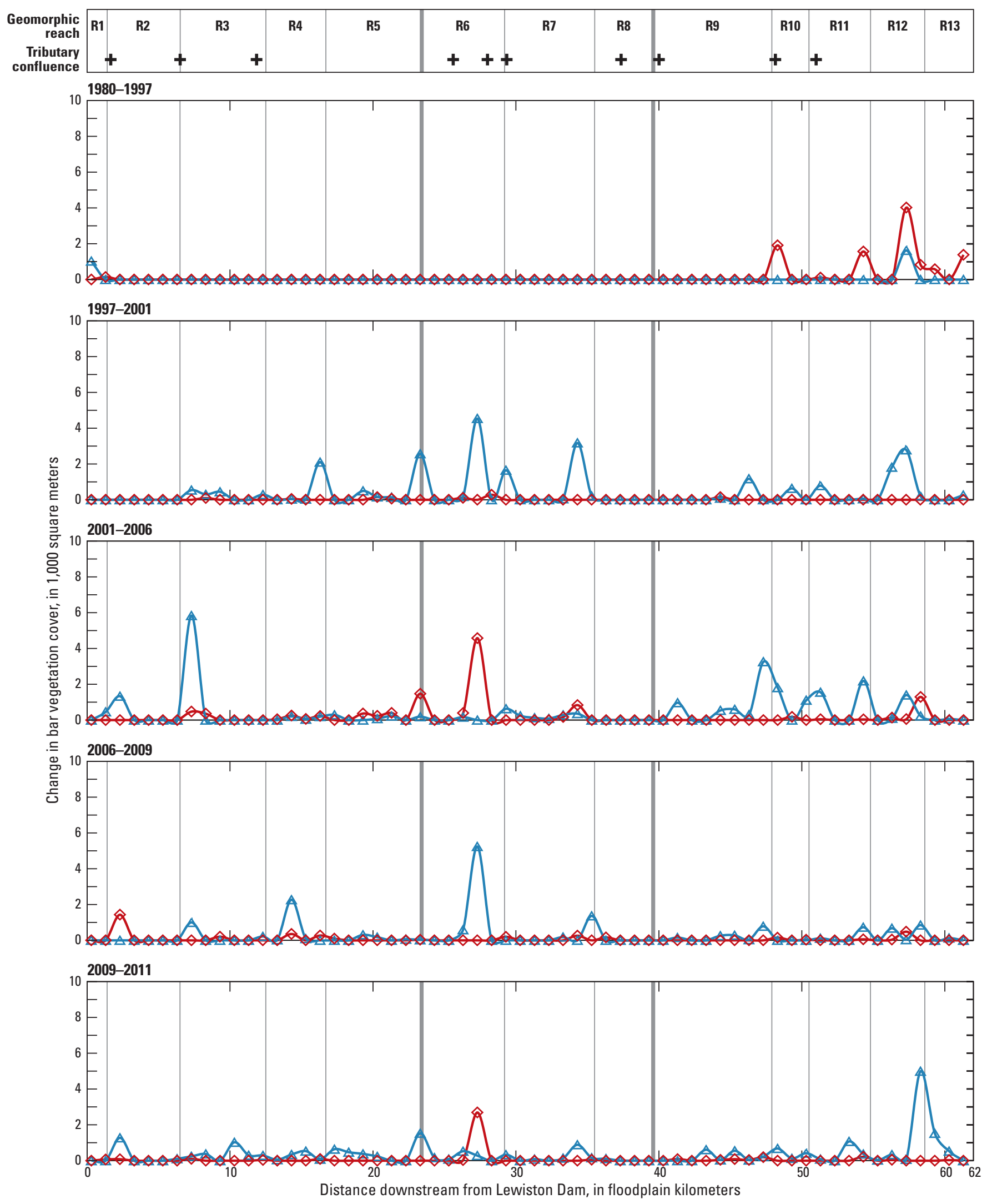

EXPLANATION

$\triangle$ Area of active bar stabilized by vegetation growth $\smile$ Area of stable bar reactivated by scour of vegetation
R8 Geomorphic reach

+ Tributary confluence

Figure 29. Changes in bar vegetation along the Trinity River downstream from Lewiston Dam, California, for five periods ending in 1997, 2001, 2006, 2009, and 2011. 


\section{Assessing Geomorphic Change along the Trinity River Downstream from Lewiston Dam, California, 1980 to 2011}

The period from 2001 to 2006 was dominated by bar scour (fig. 28), and bar stabilization from encroachment of riparian vegetation continued in the upper and lower river (fig. 29). Bar accretion occurred in the upper river downstream of Rush Creek (6.5 FPkm), but bar scour dominated downstream of Indian Creek (25.6 FPkm). System wide, about 5 percent of the active channel showed bar scour or accretion, whereas about 11 percent showed bank change (table 6). Rates of bar scour $\left(9,324 \mathrm{~m}^{2} / \mathrm{yr}\right)$ were slightly greater than bar accretion during the previous period, but the bank erosion rate $(0.23 \mathrm{~m} / \mathrm{yr})$ was similar to the previous period (table 6$)$. There was a significant tributary flood followed by a secondary spring flow release in 2006 (fig. 23), and there were 33 days with flows greater than $6,000 \mathrm{ft}^{3} / \mathrm{s}$ measured at the Lewiston gage. Management activities included small amounts of gravel augmentation in the upper river (fig. 25) and construction of the first large-scale channel-rehabilitation project in the lower river that involved surface lowering and floodplain construction (fig. 24).

From a system-wide perspective, bar and bank changes from 2006 to 2009 were relatively small compared to previous periods (table 6), but stabilization of active bars as a result of vegetation encroachment continued throughout the study area (fig. 29). There was bank erosion in upper river (fig. 27), and the largest amount of bar accretion was near the Sawmill gravel-augmentation site $(1.7 \mathrm{FPkm})$. In the lower river, the Lime Point reach $(54.8 \mathrm{FPkm})$ was the only reach that had notable bar and bank changes. System wide, about 2 percent of the active channel showed bar scour or accretion, whereas about 8 percent of the active channel showed bank changes (table 6). There was net bar accretion $\left(3,267 \mathrm{~m}^{2} / \mathrm{yr}\right)$, but bankerosion rates decreased $(0.08 \mathrm{~m} / \mathrm{yr})$ relative to the previous period $(0.23 \mathrm{~m} / \mathrm{yr})$. Tributary flows were relatively low, and there were only 7 days with flows greater than $6,000 \mathrm{ft}^{3} / \mathrm{s}$ at the Lewiston gage; however, larger volumes of gravel augmentation by direct injection began in 2008 (fig. 25), causing bar accretion in the upper river (fig. 28). Additional management actions included construction of 14 large-scale channel-rehabilitation projects in the study reach (fig. 24). Mechanical restoration included surface lowering to increase channel-floodplain connectivity and construction of channel complexity features.

Bar and bank changes increased from 2009 to 2011. In the upper river, bar accretion and bank erosion occurred near the Lowden Ranch gravel-augmentation site (11.5 FPkm). There was also net bar accretion near Indian Creek (25.6 FPkm) and downstream of Oregon Gulch (48.2 FPkm). The largest amount of bank erosion (fig. 27) was near Grass Valley Creek (11.9 FPkm) and Lime Point (58 FPkm), and stabilization of active bars by vegetation encroachment continued throughout the study area (fig. 29). System wide, about 4 percent of the active channel underwent bar scour or accretion, whereas about 9 percent of the active channel underwent bank erosion or accretion (table 6). The rate of bar accretion doubled $\left(6,505 \mathrm{~m}^{2} / \mathrm{yr}\right)$ compared to the previous period $\left(3,267 \mathrm{~m}^{2} / \mathrm{y}\right)$, and the bank erosion rate $(0.27 \mathrm{~m} / \mathrm{yr})$ increased and was comparable to estimates from 1980 to 2006 (table 6). A moderate tributary-flow event in 2011 was followed by the largest flow release since 1974 in May of 2011 (Krause, 2012a). At the Lewiston gage, there were 12 days with flows greater than $6,000 \mathrm{ft}^{3} / \mathrm{s}$ and 3 days with flows greater than $11,000 \mathrm{ft}^{3} / \mathrm{s}$. Gravel augmentation by direct injection during the flow release increased active-bar area in the upper river (fig. 28), and four large-scale channel-rehabilitation projects were constructed (fig. 24). Mechanical rehabilitation included surface lowering to increase channel-floodplain connectivity and construction of channel-complexity features.

\section{Discussion}

Our assessment of the cumulative changes in active bar and active channel areas are summarized in figure 30, which shows pre-ROD increases in the active-channel area were well distributed downstream, whereas pre-ROD increases in the active-bar area were primarily downstream of Indian Creek (25.6 FPkm). Post-ROD increases in the area of the active-channel and active-bars were primarily in the upper river upstream of Indian Creek. These interpretations are consistent with our contributing area analysis (fig. 21) and a recent sediment budget estimate (Gaeuman and Krause, 2011), which indicated a transition to a sediment surplus condition downstream of Indian Creek (25.6FPkm). In the remainder of this report, we discuss pertinent controlling factors responsible for the documented geomorphic changes.

\section{Channel Change Potential}

The study reach is in an active zone of uplift that provided a tectonic mechanism over geologic time for river incision and development of a bedrock-channel network (Anderson, 2008). Active uplift zones tend to be drained by channels with high transport capacities and low volumes of stored sediment because of the confined setting (Gilbert, 1914; Montgomery and others, 1996; Brierley and others, 2002; Wallick and others, 2010). It follows that sediment storage is often transient and concentrated near point sources or in reaches with erodible channel margins; however, watershed disturbances can result in episodic aggradation and degradation, and such is the case for the Trinity River downstream from Lewiston Dam.

The combined effects caused by the influx of largediameter mining tailings, dam construction, flow diversion, vegetation encroachment, and flood-induced confluence aggradation effectively trapped the modern channel, often against resistant bedrock valley margins, creating conditions that sustain static channel form and stable alluvial features. An unknown amount of historic channel aggradation between 1848 and 1970, as a result of gold-extraction activities, increased the sediment supply by several orders of magnitude 


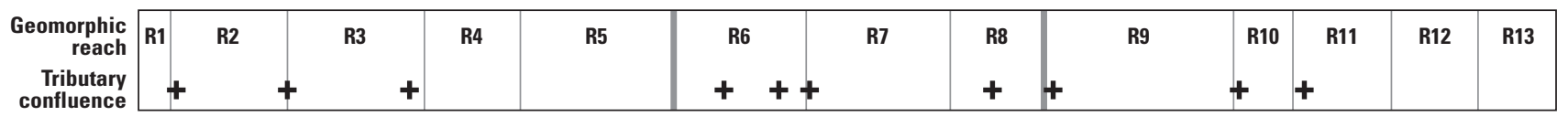
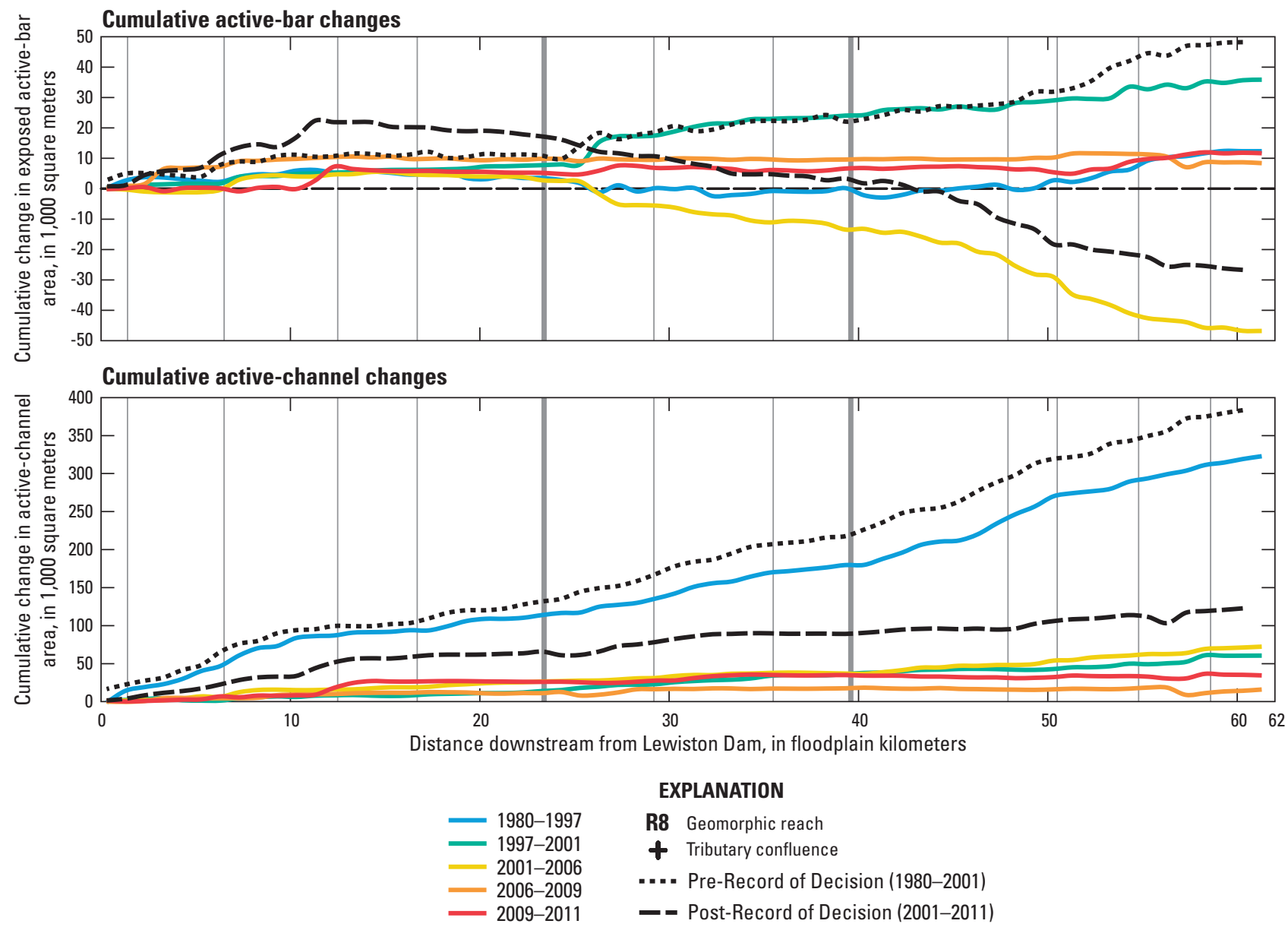

Figure 30. Cumulative downstream change in the areal extent of exposed active bars and of the active channel along the Trinity River downstream from Lewiston Dam, California, for five periods ending in 1997, 2001, 2006, 2009, and 2011.

(Krause and others, 2010; Krause, 2012b). Flow regulation and diversions that began in 1960 effectively decreased the river's transport capacity (U.S. Fish and Wildlife Service and Hoopa Valley Tribe, 1999) and enabled vegetation encroachment and stabilization of channel margins. In 1964, a massive regional flood initiated a new episode of aggradation at all major tributary confluences in the study reach (Ritter, 1968). The combined effects of these disturbances produced a narrower, partially confined, aggraded river. Although riparian encroachment continues to be an issue, the tendency toward a static channel form and stable alluvial features was disrupted by pre-ROD tributary floods and continues to be moderated by post-ROD tributary floods, increases in the size and duration of peak-flow releases, and upper-river gravel augmentation.
The upper river generally has a lower potential for dynamic geomorphic change because it lacks tributary contributions to flow and sediment supply. To resolve the lack of capacity for creating dynamic change, post-ROD channel rehabilitation, gravel augmentation, and alterations in flow management were implemented to increase and maintain active-channel areas and channel complexity. The post2006 increases in gravel augmentation provided additional sediment supply, and regulated flows were increased to support transport capacity. Beginning in 2008, a new phase of channel-rehabilitation began to include channel complexity features, such as bars and secondary water features (split-flow channels, side channels, alcoves, and aquatic wetlands). 
The potential of flow events to create channel change depends on antecedent channel conditions, transport capacity, and sediment supply. In terms of creating system-wide responses, the geomorphic effectiveness of ROD-flows is relatively low compared to tributary flows, which produce larger, longer duration flows with greater sediment delivery. Because the upper river lacked sufficient transport capacity and sediment supply, intensive post-ROD management was required to achieve the TRRP goal of promoting active alluvial processes that create and maintain the quantity and quality of available salmonid habitat. Our analyses indicated that geomorphic change induced by managed-flow releases, with concurrent gravel augmentation, tended to be spatially limited. Although the majority of the pre-2001 active bars were remobilized and scoured by the 2006 tributary flood, subsequent increases in bar vegetation indicated post-ROD flows were not sufficient to scour emergent bar vegetation and to maintain active-bar areas in reaches downstream of Indian Creek (25.6 FPkm). However, post-ROD gravel augmentation and flow management did successfully increase and maintain active-bar area in the upper river.

\section{Trajectories of Geomorphic Response and Primary Controls}

The general trajectory of change during the study period was the conversion of riparian features into channel features and an expansion of the active-channel system. During the pre-ROD period, channel widening dominated from 1980 to 1997 , followed by bar accretion from 1997 to 2001 . Although channel widening continued through the post-ROD period, 2001 to 2006 was characterized by bar scour, and there were relatively small geomorphic changes from 2006 to 2011 related to the implementation of ROD-mandated gravel augmentation, prescriptive flow releases, and channel rehabilitation.

The largest and longest duration tributary floods during the study period occurred in 1997 and 1998. The relatively wet period in the early 1980s likely initiated some of the channel changes between 1980 and 1997, but these effects were undocumented. Effects of the 1997 tributary flood were assessed (McBain and Trush, Inc., 2000), and results from the post-flood survey indicated the 1997 flow event effectively scoured channel margins downstream of the Rush Creek confluence (6.5 FPkm).

The 1980 to 1997 period was dominated by bank erosion and channel widening, and we inferred, on the basis of the post-flood reconnaissance, that much of the expansion of the active-channel area was induced by the 1997 flood. The greatest cumulative downstream increase in exposed active-bar area during the study period was from 1997 to 2001 (fig. 30), primarily downstream of the Indian Creek confluence (25.6 FPkm).

The rapid rate of accretion $\left(8,709 \mathrm{~m}^{2} / \mathrm{yr}\right.$; table 6$)$ during the relatively short period from 1997 to 2001 was facilitated by decreased transport capacity and increased sediment supply. Channel widening from 1980 to 1997 altered the river's hydraulic geometry and effectively decreased available transport capacity. Local sediment supply likely increased after 1997 because of scour of riparian vegetation and bank destabilization. We also inferred that tributary sediment supplies increased during the relatively wetter 1998 water year, when there were two large tributary floods. Gravel augmentation accounted for a relatively small portion of the increase in sediment supply during this period. A total of $3,200 \mathrm{~m}^{3}$ of coarse gravel (fig. 25), or about $800 \mathrm{~m}^{3} / \mathrm{yr}$, was added to the upper river at two locations (1.4 and 4.6 FPkm).

During the period from 2001 to 2006, the study area was dominated by bar scour, again, primarily downstream of the Indian Creek confluence (25.6 FPkm; fig. 30). Bar scour was most likely induced during a relatively wetter period that culminated in the 2006 tributary flood and a $10,400 \mathrm{ft}^{3} / \mathrm{s}$ peak-flow release (fig. 23). Bar scour during this period was slightly greater $\left(9,324 \mathrm{~m}^{2} / \mathrm{yr}\right)$ than bar accretion during the previous period $\left(8,709 \mathrm{~m}^{2} / \mathrm{yr}\right.$; table 6$)$.

Beginning in 2005, large-scale channel rehabilitation began (fig. 24), and there were concurrent increases in the frequency of flows inundating floodplains (fig.19) and gravel augmentation (fig.25). Intensified mechanical rehabilitation increased the connectivity of low-elevation riparian features (post-dam benches and constructed floodplains), and implementation of the post-ROD flow regime increased the frequency of floodplain inundation. Implementation of larger scale channel rehabilitation also increased channel complexity (fig. 8) in the form of exposed active-bar areas (fig. 16) and secondary water features (split-channels, side channels, alcoves, and aquatic wetlands; fig. 17) in the upper and central river.

During the remainder of the post-ROD period, 2006 to 2011, the active-channel area continued to increase (fig. 30), and bar changes were primarily confined to the upper river reaches that had gravel augmentation $(1.4 \mathrm{FPkm}$ and 11.5 FPkm) and downstream of the Canyon Creek confluence (51.0 FPkm). The cumulative results of intensive management in the upper river were increased channel complexity and floodplain connectivity that was maintained with managed-flow releases. Gravel augmentation was the primary factor leading to upper river increases in active-bar area, and the 2006 tributary flood was the primary factor that increased lower river active-bar area. 
During the post-ROD period, large channel changes were spatially limited to reaches that had mechanical restoration or gravel augmentation and to reaches downstream of tributary confluences, where localized excess sediment supplies or transport capacity exist. This observation was supported by earlier studies (Ritter, 1968; Trinity Restoration Associates, Inc., 1993; Hoopa Valley Tribe and others, 2011b). The exception to this generalization was the Lime Point reach (54.8 to 58.2 FPkm). The Lime Point reach was one of the most dynamic reaches during the study period. Although there was a series of rehabilitation projects constructed in this reach in 2006 and 2010, dynamic channel changes were primarily in un-rehabilitated reaches. The greatest bar and bank changes were in the lowermost section of the Lime Point reach $(58 \mathrm{FPkm})$, which is in an incised meander bend that has a relatively small radius of curvature, which produces large bed-shear stresses and high transport capacity.

We constructed a series of figures to show the cumulative pre- and post-ROD changes in representative reaches. Figure 31 shows a portion of the primary spawning reach and the Sven Olbertson rehabilitation site (1.0 FPkm) in the upper river downstream from Lewiston Dam. Intensive management of this reach during pre- and post-ROD periods included gravel augmentation, mechanical restoration, and peak-flow releases that increased the active-channel area, channel complexity, and floodplain connectivity.

Figures 32, 33, and 34 show a series of reaches in the lower river where there was dynamic channel change. Figure 32 illustrates bank erosion and bar accretion near Junction City, Calif. (50.1 FPkm), upstream from the Canyon Creek confluence. Pre-ROD erosion of the left bank and deposition of lateral bars resulted in about $25 \mathrm{~m}$ of channel migration between 1980 and 2001. Post-ROD bank erosion continued to expand the active-channel area, and there was concurrent bar accretion, bar scour, and stabilization of a downstream lateral bar. Channel complexity also increased with the number of bars and secondary water features. Figure 33 shows the upstream portion of the Conner Creek rehabilitation site $(53.8 \mathrm{FPkm})$, where the deposition of large pre-ROD bars increased channel complexity and sinuosity. During the post-ROD period, there was bar scour, bar stabilization, and bank erosion that expanded the active-channel area, and rehabilitation of the channel margin increased riparian diversity with floodplain construction. Figure 34 illustrates Lime Point (58.1 FPkm), where a pre-ROD channel avulsion was accompanied by bar scour and bar deposition, which increased channel complexity and the active-channel area. During the post-ROD period, a large medial bar was stabilized by vegetation encroachment, and the active channel area decreased, but the 1980-era channel continued to function as a side channel, and new bar features formed.

\section{Geomorphology and Habitat Linkages}

To support the TRRP adaptive management program, we evaluated the relative effectiveness of natural and managed controlling factors and the associated cumulative geomorphic response during the five study periods. We also assessed a set of performance measures (channel complexity, shoreline length, and channel-floodplain connectivity) identified by the TRRP as primary metrics for characterizing linkages between geomorphic structure and available salmonid habitat (Trinity River Restoration Program and ESSA Technologies Ltd., 2009).

Measures of channel complexity included exposed active-bar area (fig. 16) and secondary water features (fig. 17). There were greater increases in channel complexity during the pre-ROD period than during the post-ROD period. System-wide channel complexity increased markedly from 1980 to 1997 and then decreased slightly from 1997 to 2001. During the post-ROD period system-wide channel complexity decreased slightly, but there were smaller, yet measurable, increases in channel complexity in the upper river.

An integrated habitat assessment (U.S. Fish and Wildlife Service and others, 2011) of channel-rehabilitation projects constructed from 2005 to 2009 concluded that the only metric well correlated to fish use was the length of the wettedchannel edge, or shoreline length. During the study period, the largest increase in shoreline length (fig. 18A) was during the pre-ROD period, primarily in the upper river, as a result of extensive side-channel construction and bar accretion. There were smaller, but measurable, increases in shoreline length during the post-ROD period, primarily after 2006 , related to channel rehabilitation.

Increases in channel-floodplain connectivity were inferred from the areal extent of constructed floodplains and by increases in the size and frequency of post-ROD flow releases. During the pre-ROD period in the early 1990s, small-scale riparian berm removal and feathered-edge construction increased floodplain connectivity (fig. 24). Extensive scour of riparian vegetation during the 1997 tributary flood resulted in additional increases in floodplain connectivity, primarily downstream from Indian Creek (25.6 FPkm; fig. 29). During the post-ROD period, riparian vegetation was scoured near tributary confluences from 2001 to 2006 (fig. 29), and there was a relatively large increase in constructed floodplain area from 2005 to 2011 (fig. 25). Post-ROD increases in the areal extent of lower-elevation floodplains, inundated by flows greater than about $4,500 \mathrm{ft}^{3} / \mathrm{s}$, and concurrent increases in the frequency of exceedance (table 1) indicated a larger proportion of riparian features were inundated annually during the post-ROD period. 

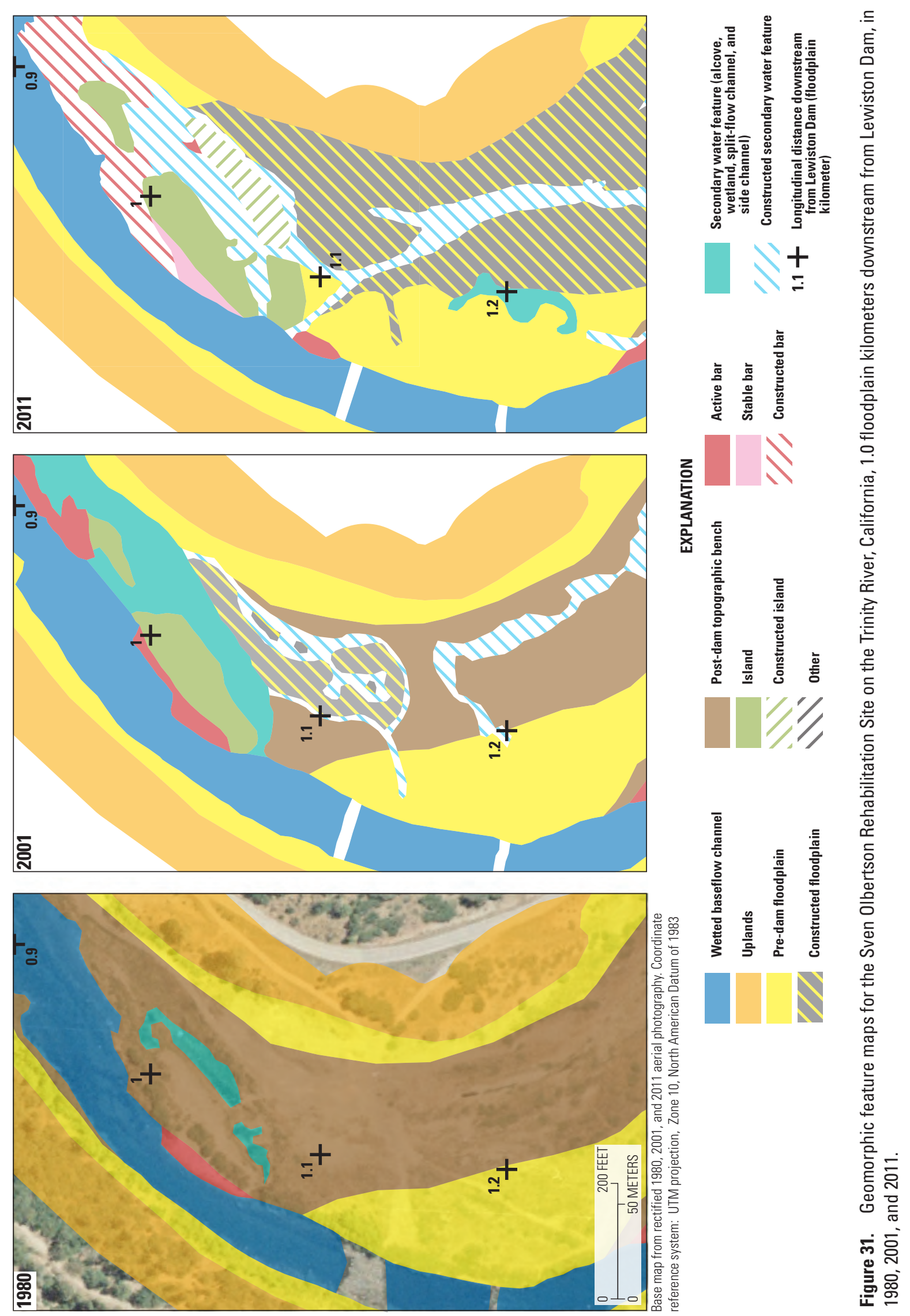

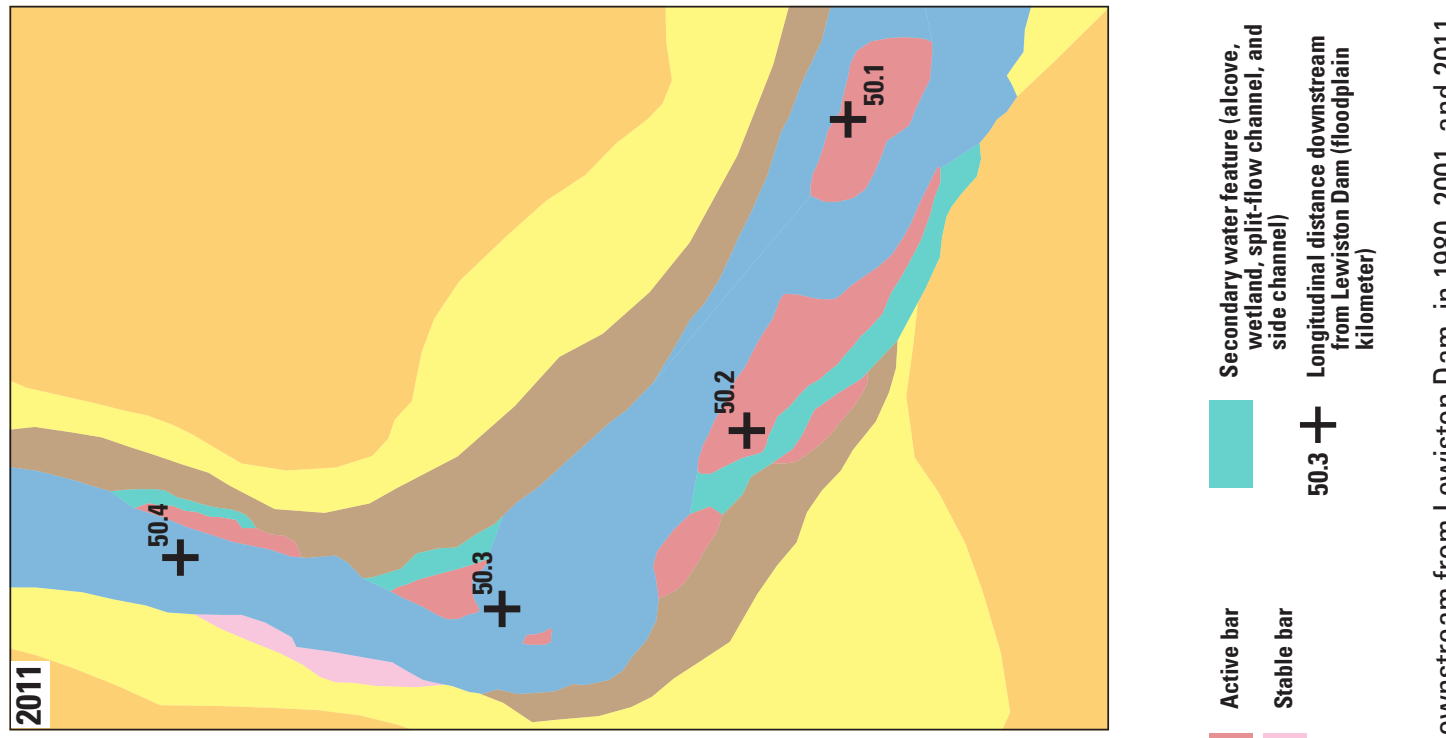



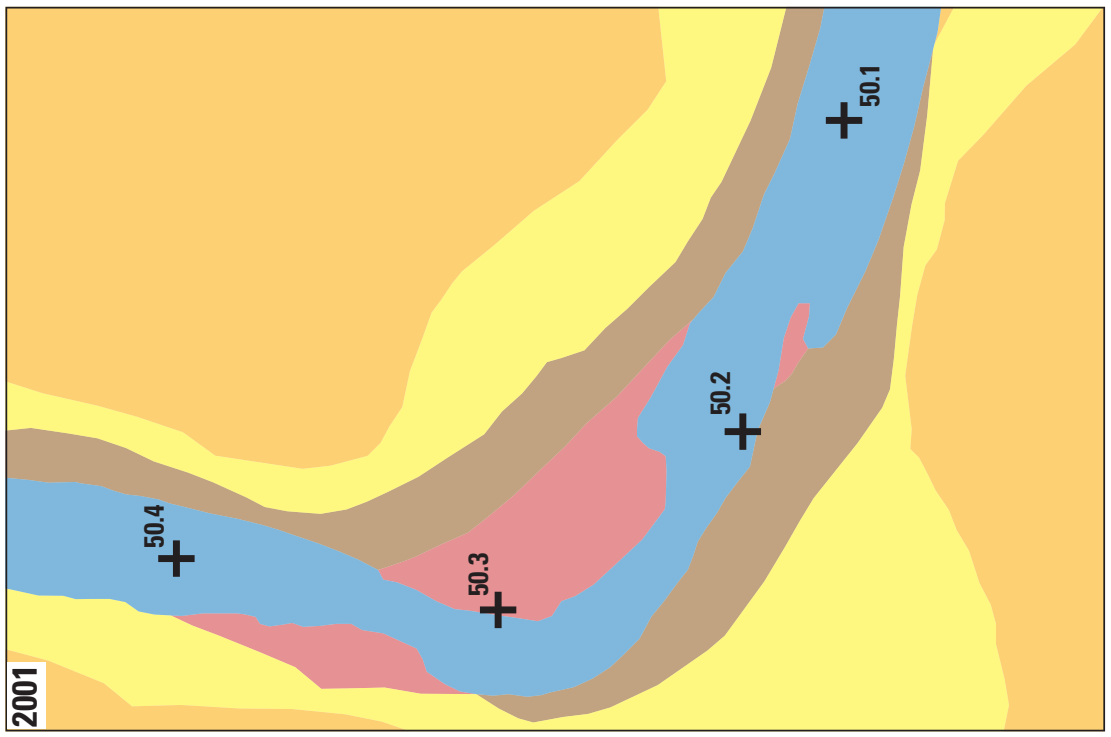

을

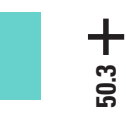

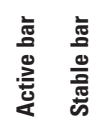



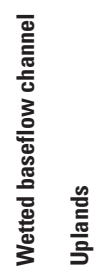

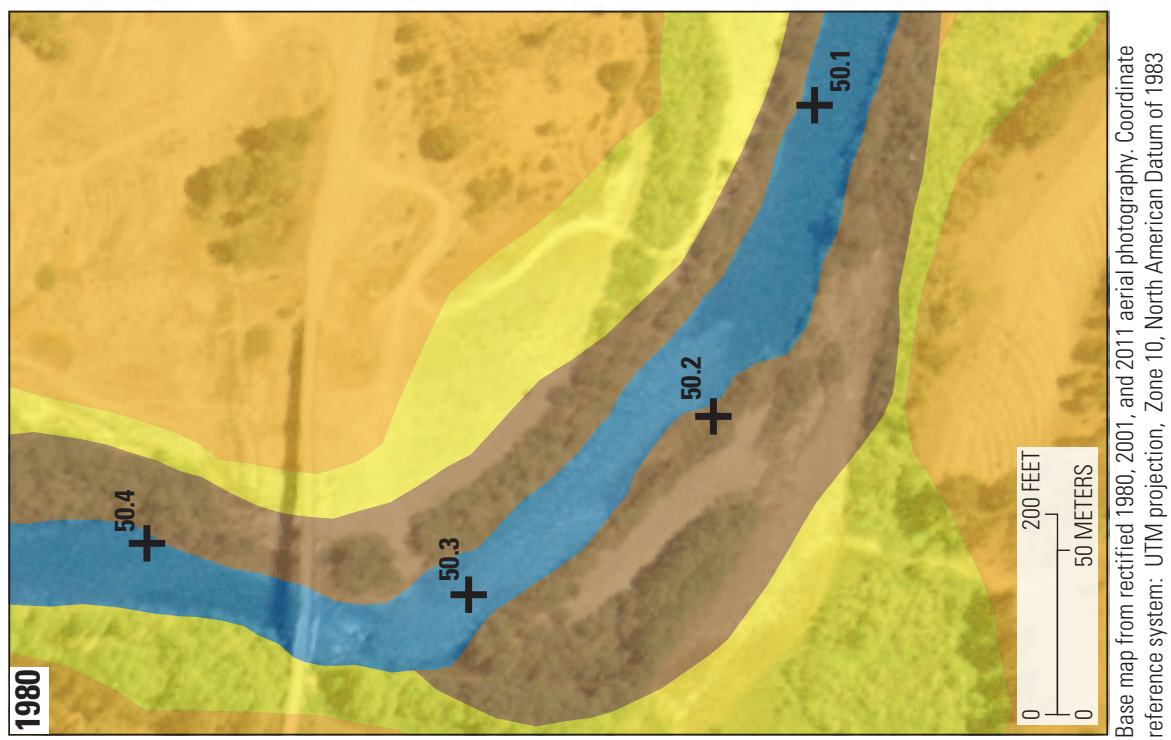



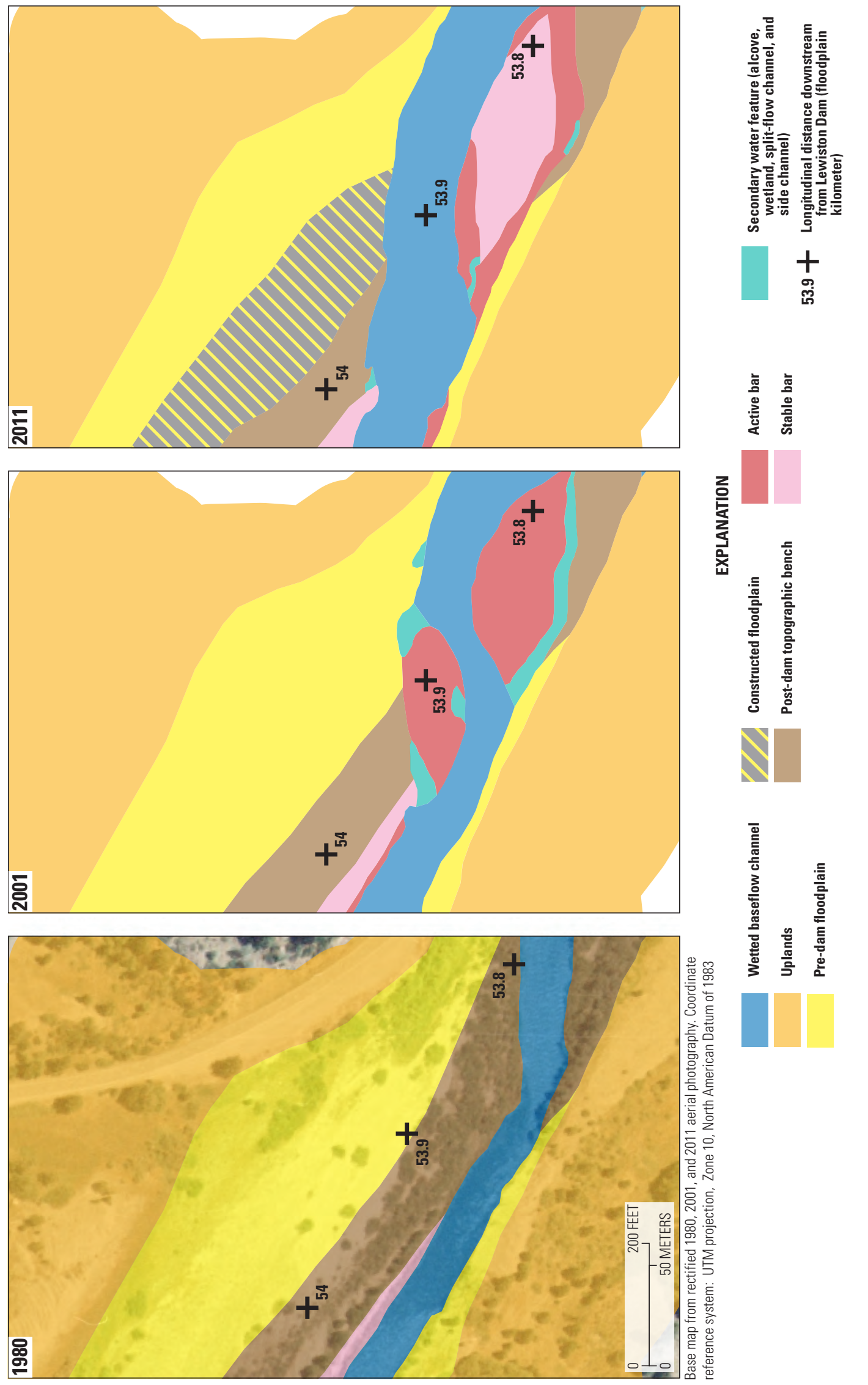

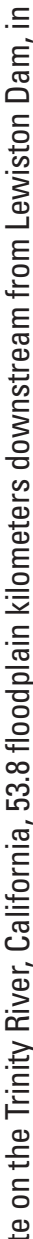
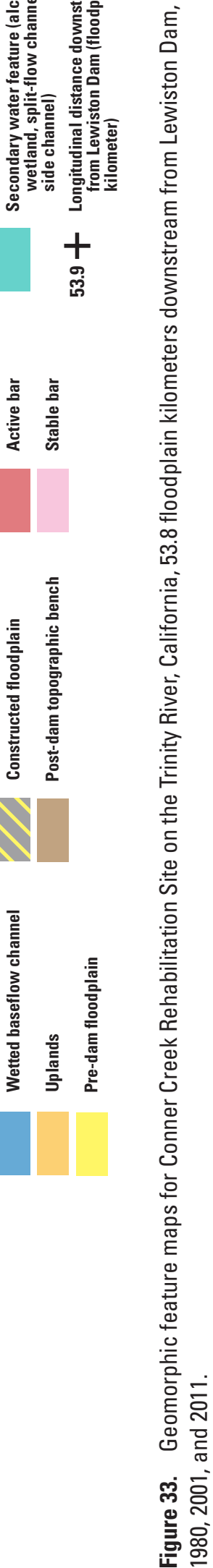

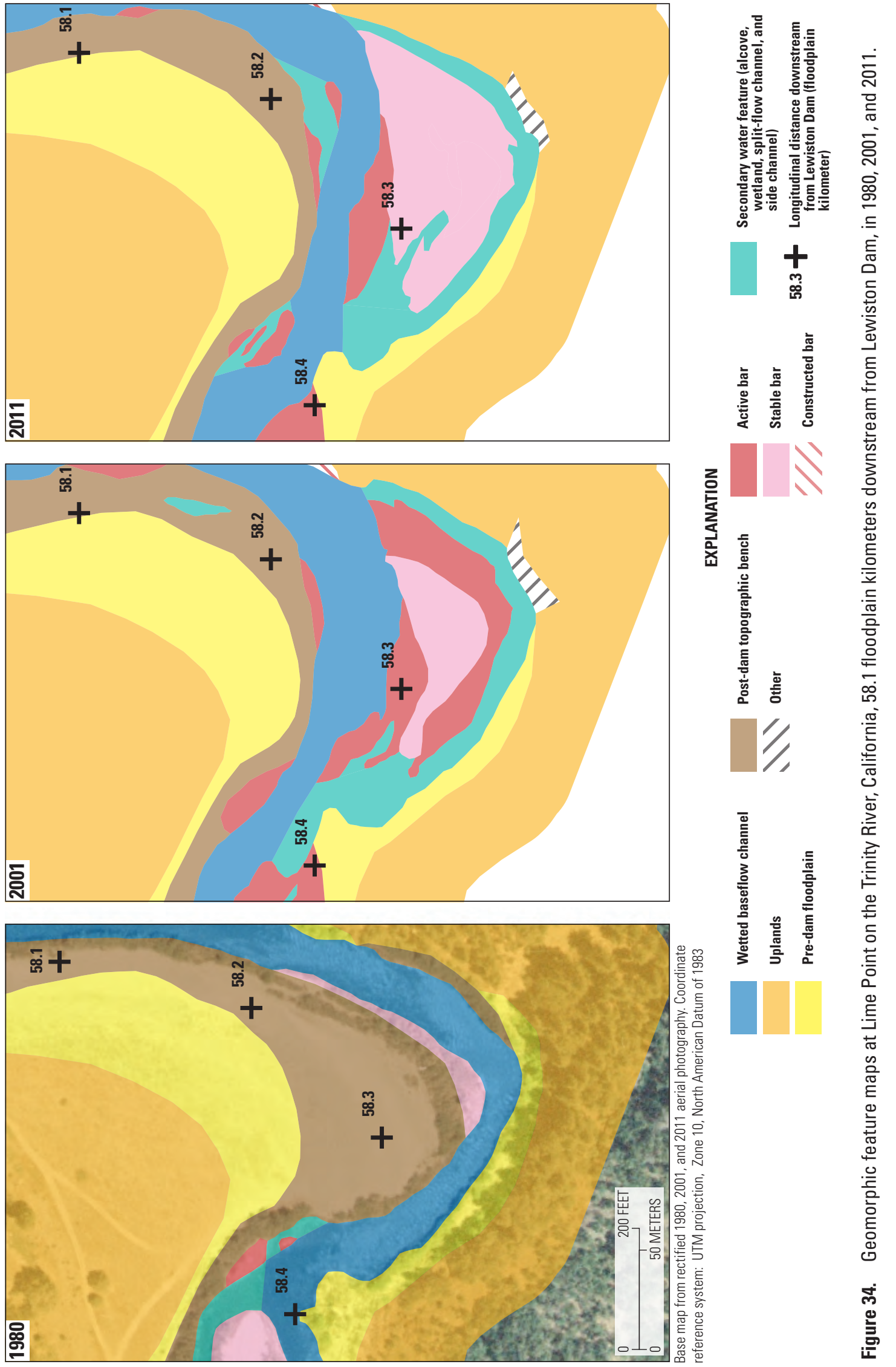


\section{Assessing Geomorphic Change along the Trinity River Downstream from Lewiston Dam, California, 1980 to 2011}

\section{Conclusions}

This report documents a geomorphic assessment of a $65-\mathrm{km}$ study reach along the Trinity River, California, downstream of Lewiston Dam. A series of geomorphic maps were used to characterize trajectories of geomorphic change and to investigate the evolution of geomorphic features and alluvial processes for one of the nation's largest adaptively managed river restoration programs. The maps illustrate a system-wide perspective of evolving geomorphic features governed by natural processes and management actions from 1980 to 2011 . The 1980 to 1997 period was dominated by channel widening, primarily induced by the 1997 tributary flood, and accompanied by smaller increases in active-bar area. This period of channel widening was followed by extensive bar accretion, primarily downstream of Indian Creek, from 1997 to 2001. Bar and channel margins, scoured by large tributary floods in 1997 and 1998, were recolonized by vegetation as early as 2001 . The beginning of the post-ROD period, from 2001 to 2006, was characterized by bar scour slightly greater than bar accretion during the previous period, again, primarily downstream from Indian Creek. From 2006 to 2011, there were smaller, but measurable geomorphic changes, but these were generally limited to gravel-augmentation sites in the upper river, mechanical channel-rehabilitation sites, tributary confluences, and lower river reaches that had sufficient transport capacity and sediment supply.

The general trajectory of change from 1980 to 2011 was a system-wide increase in riparian diversity and conversion of riparian features to channel features, such that the active-channel area and channel complexity increased. During the longer (21 years) and relatively wetter pre-ROD period, increases in active-channel area and channel complexity were 20 and 70 percent, respectively. In 1980, the pre-dam floodplain and post-dam benches were the primary riparian features. Pre-ROD changes in riparian diversity included an increase in constructed floodplain and stable bar areas. The post-ROD period was shorter (10 years), relatively drier, had intensified management, and there were small, but measurable, increases in active-channel area (5 percent) and decreases in channel complexity ( 3 percent). Post-ROD changes in riparian diversity included large increases in constructed floodplain area and smaller increases in stable bar area.

Parsing out responses to individual causal mechanisms is exceedingly complex with numerous and concurrent natural and managed controlling factors operating at the watershed to reach scale. We determined the primary drivers of change during the wetter pre-ROD period were sequential tributary floods in 1997 and 1998 that produced channel widening (1997) following by bar accretion (1998). During the relatively drier post-ROD period, there were measurable increases in channel complexity, shoreline length, riparian diversity, and channel-floodplain connectivity, which can be attributed to the 2006 tributary flood, mechanical restoration, gravel augmentation, and managed flow increases. Since 2006, restoration efforts successfully increased exposed active-bar areas by using gravel augmentation in the upper river, and these active-bars were maintained with managedflow releases. System-wide riparian diversity and floodplain connectivity peaked in 2011, and constructed floodplains were inundated for the first time by the 2011 peak-flow release. Channel complexity peaked in the central and lower river in 2001 and subsequently decreased as a result of natural scour and bar stabilization by vegetation encroachment. In the upper river, channel complexity peaked in 2011 as a result of gravel augmentation and construction of channel-complexity features.

Our analysis of tributary floods and managed peak-flow releases indicated tributary floods have the potential to initiate larger and more extensive geomorphic change than managed peak-flow releases. During the study period, tributary-flows in 1997, 1998, and 2006 delivered an unknown, yet presumably large, amount of flow and sediment to the mainstem study reach. We inferred that increases in transport capacity and sediment supply during these tributary floods resulted in the greatest channel changes during the study period.

The regulated-flow strategy in use at the time of writing largely decouples mainstem flows from tributary flows in terms of timing. The annual peak flow releases from Lewiston Dam begin in May, whereas tributary contributions are distributed through the winter and spring. An alternative strategy for inducing system-wide dynamic bar and bank processes would be to coordinate managed-flow releases from Lewiston Dam to coincide with tributary flooding. Also, the muted and spatially limited physical response to flow releases during the post-ROD period highlights the need for continued monitoring and assessment of the magnitude, duration, and timing of prescriptive flows and associated geomorphic response.

Channel widening from 1980 to 1997 represented a threshold disturbance resulting in a system-wide decrease in transport capacity, which was likely a primary factor governing active-bar deposition from 1997 to 2001. Bed-mobility studies in the mid-1990s determined that 80 percent of the low-flow channel margin was mobilized at 6,000 ft 3 s (Trinity Restoration Associates, Inc., 1993; Wilcock and others, 1995; McBain and Trush, Inc., 1997). After 1997, studies showed that $6,000 \mathrm{ft}^{3} / \mathrm{s}$ did not produce the expected scour, mobility, or channel maintenance targets (Hoopa Valley Tribe and others, 2011b). These observations indicate that pre-ROD channel widening could have altered channel hydraulics, such that flows required to produce targeted geomorphic objectives need to be increased. Achieving the TRRP goal of a downscaled dynamic river could come with the unexpected consequence of a larger active-channel area that requires periodic higher maintenance flows. 
Expansion of the geomorphic feature database (Curtis and Guerrero, 2015; http://dx.doi.org/10.5066/F7TT4P04) to include additional study periods and additional physical attributes would support disturbance-response analyses, interpretation of the linkages between geomorphology and physical habitat, and could be used to refine conceptual models and test hypotheses highlighted as a fundamental component of adaptive management (Trinity River Restoration Program and ESSA Technologies Ltd, 2009). Rectified orthophotography from 1944, 1960, and 1975 exists. Expanding the retrospective mapping to include the pre-1980 orthophotography would enable assessment of legacy influences related to hydraulic and dredge mining and the 1955, 1964, and 1974 floods. More detailed mapping of the type and density of riparian vegetation within the framework of the existing geomorphic feature maps would enable refinement of the active-channel boundary and bar-stability classification. This study used a relatively simple bar classification that included lateral and medial bars. For the more recent periods, the bar classification could be expanded to include additional morphologic and topographic attributes and to include additional field reconnaissance and mapping of hydraulic controls to support the assessment of bar-forcing mechanisms.

Geomorphic change was strongly influenced by the relation between transport capacity and sediment supply, which varied in space and time. The lack of spatially distributed estimates of transport capacity and sediment supply severely hindered the controlling factor analysis. A series of physical models that link tributaries and the mainstem study reach, and characterize flow and sediment flux, would be useful for interpreting the spatial distribution of transport capacity and sediment supply and for developing testable hypotheses regarding potential geomorphic changes under present and future conditions. Spatially distributed estimates of transport capacity and sediment supply would also support a more detailed disturbance-response analysis and assessment of the effectiveness of channel-maintenance flows, gravel-augmentation prescriptions, and channel-rehabilitation design criteria.

\section{References Cited}

Anderson, K.T., 2008, Inferring bedrock uplift in the Klamath Mountains Province, from river profile analysis and digital topography, Master's Thesis, Texas Tech University, Tex., 314 p.

Brierley, G.J., Fryirs, K., Outhet, D., Massey, C., 2002, Application of the river styles framework as a basis for river management in New South Wales, Australia: Applied Geography v. 22 no. 1, p. 91-122. http://dx.doi.org/10.1016/ S0143-6228(01)00016-9.
California Department of Water Resources Northern District, 2007, Trinity River Hydraulic Flow Study North Fork Trinity to Lewiston Dam: Sacramento, California, 85 p., http://odp.trrp.net/FileDatabase/Documents/DWR HydraulicFlowStudyReport_forTRRP_Final_2007071.pdf.

Church, M., 2002, Geomorphic thresholds in riverine landscapes: Freshwater Biology, v. 47, p. 541-557. DOI: 10.1046/j.1365-2427.2002.00919.x.

Curtis, J.A., and Guerrero, T.M. 2015, Geomorphic mapping to support river restoration on the Trinity River downstream from Lewiston Dam, California, 1980-2011: U.S. Geological Survey Open File Report, OFR-5046, xp.

Diller, J.S., 1902, Topographic development of the Klamath Mountains: Washington, D.C., U.S. Geological Survey Bulletin, v. 196, p. 69. http://pubs.usgs.gov/bul/0196/report. pdf.

Draut, A.E., Logan, J.B., McCoy, R.E., McHenry, M., and Warrick, J.A., 2008, Channel evolution on the lower Elwha River, Washington, 1939-2006: U.S. Geological Survey, Scientific Investigations Report 2008-5127, 26 p., http:// pubs.usgs.gov/sir/2008/5127/.

Draut, A.E., Logan, J.B., and Mastin, M.C., 2011, Channel evolution on the dammed Elwha River, Washington, USA: Geomorphology, v. 127, p. 71-87, doi:10.1016/j. geomorph.2010.12.008.

Gaeuman, D., 2008, Recommended quantities and gradation for long-term coarse sediment augmentation downstream from Lewiston Dam: Weaverville, Calif., Trinity River Restoration Program, Technical Report TM-TRRP-2008-2, 16 p. http://odp.trrp.net/FileDatabase/Documents/ TM-TRRP-2008_21.pdf.

Gaeuman, D., and Krause, A.F., 2011, 2010 Bed-material sediment budget update, Trinity River, Lewiston Dam to Douglas City, California: Trinity River Restoration Program Technical Report TM-TRRP-2011-2: Weaverville, Calif., 24 p. http://odp.trrp.net/FileDatabase/Documents/ Gaeuman\%20Krause\%20\%282011\%29\%202010\%20 Bed-material\%20sediment $\% 20$ budget $\% 20$ update... TR-TRRP-2011_21.pdf.

Gallagher, S.P, 1995, Evaluation of the feathered edge restoration projects on the Trinity River: fish use and physical habitat: Sacramento, Calif., U.S. Fish and Wildlife Service, Division of Ecological Services, In-stream Flow Branch, 28 p.

Gilbert, G.K., 1914, The transport of debris by running water: U.S. Geological Survey Professional Paper 86, 263 p. http:// pubs.usgs.gov/pp/0086/report.pdf. 
Graham Matthews and Associates, 2001, Sediment source analysis for the mainstem Trinity River, Trinity County, California, Final Report to Tetra Tech, Inc.: Fairfax, Va., 190 p. http://www.krisweb.com/biblio/trinity_tetratech gma_2001_sediment.pdf.

Graham Matthews and Associates, 2012, Trinity River WY2011 sediment transport monitoring final report, Prepared for the Trinity River Restoration Program: Weaverville, Calif., 144 p. http://odp.trrp.net/FileDatabase/ Documents/GMA\%20\%282012\%29\%20Trinity\%20 River\%20WY2011\%20Sediment\%20Transport\%20 Monitoring1.pdf.

Grams, P.E., and Schmidt, J.C. 2002, Streamflow regulation and multi-level flood plain formation: channel narrowing on the aggrading Green River in the eastern Uinta Mountains, Colorado and Utah: Geomorphology, v. 44, p. 337-360. http://dx.doi.org/10.1016/S0169-555X(01)00182-9.

Grant, G. E. and Swanson, F. J., 1995, Morphology and Processes of Valley Floors in Mountain Streams, Western Cascades, Oregon, in Costa, J.E., Miller, A.J., Potter, K.W., and Wilcock P.R., eds., Natural and Anthropogenic Influences in Fluvial Geomorphology: Washington, D. C., American Geophysical Union. doi: 10.1029/GM089p0083.

Hoopa Valley Tribe, McBain \& Trush, Inc., and Northern Hydrology and Engineering, 2011a, Channel rehabilitation design guidelines for the mainstem Trinity River: Prepared for the Trinity River Restoration Program, Hoopa, Calif., 338 p. http://odp.trrp.net/FileDatabase/Documents/ Trinity $\% 20$ River $\% 20$ Channel $\% 20$ Design $\% 20$ Guide $\% 20$ 1-21-11\%20reduced2.pdf.

Hoopa Valley Tribe, U.S. Fish and Wildlife Service, and Yurok Tribe, 2011b, Integrated habitat assessment of the Upper Trinity River, 2009: Draft Report: Prepared for the Trinity River Restoration Program, Hoopa, Calif., 336 p.

Hughes, M.L., McDowell, P.F., and Marcus, W.A., 2006, Accuracy assessment of georectified aerial photographsImplications for measuring lateral channel movement in GIS: Geomorphology, v. 74, p. 1-16. http://dx.doi. org/10.1016/j.geomorph.2005.07.001.

Ingersoll, R.V., and Schweickert, R.A., 1986, A platetectonic model for Late Jurassic Ophiolite Genesis, Nevadan orogeny and forearc initiation, northern California: Tectonics, v. 5, no. 6, p. 901-912. doi:10.1029/ TC005i006p00901.

Irwin, W., 1972, Terranes of the western Paleozoic and Triassic belt in the southern Klamath Mountains, California: U.S. Geological Survey Professional Paper 800-C, p. 103-111. http://pubs.usgs.gov/pp/0800c/report. pdf.
Irwin, W.P., 1981, Tectonic accretion of the Klamath Mountains, in Ernst, W.G., ed., The geotectonic development of California (Rubey Volume 1): PrenticeHall, Englewood Cliffs, N.J., p. 29-49.

Irwin, W.P., 1994, Geologic map of the Klamath Mountains, California and Oregon: U.S. Geological Survey Miscellaneous Investigations Series Map I-2148, scale 1:500,000. http://pubs.er.usgs.gov/publication/i2148.

Knott, J.M., 1974, Sediment discharge in the Trinity River Basin, California: U.S. Geological Survey Water Resources Investigation 73-49, 56 p. http://pubs.er.usgs.gov/ publication/wri7349.

Kondolf, G.M., and Minear, J.T., 2004, Coarse sediment augmentation on the Trinity River below Lewiston Dam: Geomorphic Perspectives and Review of Past Projects, Report to the Trinity River Restoration Program, 67 p. http:/odp.trrp.net/FileDatabase/Documents/Kondolf, \%20 G\%20and\%20Minear,\%20J\%20\%282004\%29\%20 Coarse $\% 20$ sediment $\% 20$ augmentation $\% 20$ on $\% 20$ the $\% 20$ Trinity\%20River...2.pdf.

Krause, A.F., 2012a, Flow releases and diversions and the Trinity River, CA: Water Year 2011: Weaverville, Calif., Bureau of Reclamation, Trinity River Restoration Program, Technical Report, TR-TRRP-2012-1. http://odp.trrp.net/ FileDatabase/Documents/Krause \%202012\%20Flow\%20 Releases\%20and\%20Diversions \%20on\%20the\%20 Trinity\%20River\%20WY20111.pdf.

Krause, A.F., 2012b, History of mechanical sediment augmentation and extraction on the Trinity River, California, 1912-2011: Trinity River Restoration Program Technical Report, TR-TRRP-2012-2, 49 p. http://odp. trrp.net/FileDatabase/Documents/Krause\%20(2012)\%20 History $\% 20$ of $\% 20$ mechanical $\% 20$ sediment $\% 20$ augmentation $\% 20$ and $\% 20$ extraction $\% 201912 \% 20-\% 20$ 2011.Revised1.pdf.

Krause, A.F., Wilcock, P.R., Gaeuman, D., 2010, One hundred and fifty years of sediment manipulation on the Trinity River, Calif.: In Proceedings of the 9th Joint Federal Interagency Conference on Sedimentation and Hydrologic Modeling, Las Vegas, Nev., June 27, 2010-July 1, 2010. http://acwi.gov/sos/pubs/2ndJFIC/Contents/3D_ Krause_3_1_10.pdf.

McBain \& Trush, Inc., 1997, Trinity River maintenance flow study_Final report: Arcata, Calif., prepared for the Hoopa Valley Tribe, McBain and Trush, Inc., 482 p. http://odp.trrp. net/FileDatabase/Documents/Trinity\%20Maintenance\%20 Flow\%20Study\%20-\%20November\%201997.pdf. 
McBain \& Trush, Inc., 2000, Evaluation of 1997 flood impacts on Riparian Berms along the Trinity River, CaliforniaFinal Report: Arcata, Calif., prepared for the Hoopa Valley Tribe, McBain and Trush, Inc., 27 p. http://odp.trrp.net/ FileDatabase/Documents/MT\%20\%282000\%29\%20 Evaluation\%20of\%201997\%20Flood\%20Impacts\%20 on\%20Riparian\%20Berms1.pdf.

Micheli, E.R., Kirchner, J.W., and Larsen, E.W., 2004, Quantifying the effect of riparian forest versus agricultural vegetation on river meander migration rates, Central Sacramento River, California, U.S.A.: River Research and Applications, v. 20, no. 5, p. 537-548. doi: 10.1002/rra.756.

Montgomery, D.R., and Buffington, J.M. 1998, Channel processes, classification, and response, chapter 2 in Naiman, R., and Bilby, R., eds., River Ecology and Management: New York, N.Y., Springer-Verlag Inc., p. 13-42.

Montgomery, D.R., Abbe, T.B., Buffington, J.M., Peterson, N.P., Schmidt, K.M., and Stock, J.D., 1996, Distribution of bedrock and alluvial channel in forested mountain drainage basins: Nature, v. 381, p. 587-589. doi:10.1038/381587a0 http://www.fs.fed.us/rm/boise/publications/watershed/ rmrs_1998_montomeryr001.pdf.

Mount, N.J., and Louis, J., 2005, Estimation and propagation of error in the measurement of river channel movement from aerial imagery: Earth Surface Processes and Landforms, v. 30, no. 5, p. 635-643. DOI: 10.1002/ esp. 1172 .

O’Connor, J.E., Jones, M.A., Haluska, T.L., 2003, Flood plain and channel dynamics of the Quinault and Queets Rivers, Washington, USA: Geomorphology v. 51, p. 31-59. http:// dx.doi.org/10.1016/S0169-555X(02)00324-0.

Pitlick, J. and Wilcock, P.R, 2001, Relations between Streamflow, Sediment Transport, and Aquatic Habitat in Regulated Rivers, in Dorava, J.M., Montgomery, D.R., Palcsak, B.B, and Fitzpatrick, F. A., eds, Geomorphic Processes and Riverine Habitat: Washington, D. C., American Geophysical Union, p. 185-198. doi: 10.1029/ WS004p0185.

Schmidt, J.C., and Wilcock, P.R., 2008, Metrics for assessing the downstream effects of dams: Water Resources Research, W04404. doi:10.1029/2006WR005092.

Schmidt, J.C., Grams, P.E., and Leschin, M.F., 1999, Variation in the magnitude and style of deposition and erosion in three long $(8-12 \mathrm{~km})$ reaches as determined by photographic analysis, in Webb, R.H., Schmidt, J.C., Valdez, R.A., and Marzolf, G.R., eds., The Controlled Flood in Grand Canyon: Washington, D.C., American Geophysical Union, p. 185-203. doi: 10.1029/GM110p0185.
Stearns, J.G., 1969, Task force report on sediment problems in the Trinity River near Lewiston, State of California: Sacramento, California Resources Agency, 159 p. http:// odp.trrp.net/FileDatabase/Documents/Sediment $\% 20$ Problems\%20in\%20the\%20Trinity\%20River,\%20Near\%20 Lewiston\%2019691.pdf.

Trinity Restoration Associates, Inc., 1993, Trinity River maintenance flow report: evaluation of the $6,000 \mathrm{cfs}$ release: Report to Hoopa Valley Indian Tribe Fisheries Department, 140 p. http://www.fws.gov/arcata/fisheries/reports/technical/ Trinity_River_Channel_Maintenance_Flow_Study_Final_ Report.pdf.

Trinity River Restoration Program and ESSA Technologies Ltd, 2009, Integrated Assessment Plan, Version 1.0September 2009: Draft report prepared for the Trinity River Restoration Program, Weaverville, Calif., 285 p. http://odp. trrp.net/FileDatabase/Documents/IAP_1.01.pdf.

Trinity River Taskforce, 1970, Task force findings and recommendations on sediment problems in the Trinity River near Lewiston and a summary of the watershed investigation: California Resources Agency, 29 p.

Trinity River Taskforce, 1979, Delta formations at the mouths of tributary streams: California Resources Agency, 6 p.

U.S. Bureau of Land Management, 1995, Mainstem Trinity River watershed analysis: Redding Resource Area, 74 p. http:/www.fs.usda.gov/Internet/FSE_DOCUMENTS/ stelprdb5380151.pdf.

U.S. Department of the Interior, 2000, Record of Decision, Trinity River mainstem fishery restoration, Final Environmental Impact Statement/Environmental Impact Report, 43p. http://odp.trrp.net/FileDatabase/Documents/ Trinity\%20River\%20Record\%20of\%20Decision\%2012-1900.pdf.

U.S. Fish and Wildlife Service, 1980, Environmental impact statement on the management of river flows to mitigate the loss of the anadromous fishery of the Trinity River, California, Volume I: Sacramento, California, 229 p. http://odp.trrp.net/FileDatabase/Documents/Enviro\%20 Impact $\% 20$ Statement $\% 20$ Vol.\%201\%201980b1.pdf.

U.S. Fish and Wildlife Service, 1989, Annual report, Klamath River fisheries assessment program juvenile salmonid production monitoring, 1988: Report No. AFF-FAO-89-12: Arcata, Calif., U.S. Fish and Wildlife Service, 19 p. http:// odp.trrp.net/FileDatabase/Documents/Juvenile_Salmonid_ Monitoring_on_the_Klamath_and_Trinity_Rivers_-_19881. pdf. 
U.S. Fish and Wildlife Service, 1994, Restoration of the mainstem Trinity River background report, Trinity River Restoration Program: Weaverville, Calif., U.S. Fish and Wildlife Service, 14 p. http://odp.trrp.net/FileDatabase/ Documents/Restoration $\% 20$ of $\% 20$ the $\% 20$ Mainstem $\% 20$ TR\%20Background\%20Report\%2019941.pdf.

U.S. Fish and Wildlife Service and Hoopa Valley Tribe, 1999, Trinity River Flow Evaluation Study: Final Report, 310 p. http://odp.trrp.net/FileDatabase/Documents/USFWS $\% 20$ HVT\%201999\%20(June\%20FINAL\%20-\%20locked)\%20 Trinity $\% 20$ River $\% 20$ Flow\%20Evaluation $\% 20$ Final $\% 20$ Report1.pdf.

Wallick, J.R., Anderson, S.W., Cannon, Charles, and O’Connor, J.E., 2010, Channel change and bed-material transport in the lower Chetco River, Oregon: U.S. Geological Survey Scientific Investigations Report 2010-5065, 68 p. http://pubs.usgs.gov/sir/2010/5065/pdf/ sir20105065.pdf.

Wallick, J.R., O’Connor, J.E., Anderson, S., Keith, M., Cannon, C., and Risley, J.C., 2011, Channel change and bed-material transport in the Umpqua River basin, Oregon: U.S. Geological Survey Scientific Investigations Report 2011-5041, 112 p. http://pubs.usgs.gov/sir/2011/5041/pdf/ sir20115041.pdf.
Wilcock, P.R., Kondolf, G.M., Barta, A.F., Matthews, W.V.G., and Shea, C.C., 1995, Spawning gravel flushing during trial reservoir releases on the Trinity River: Field observations and recommendations for sediment maintenance flushing flows: Prepared for the U.S. Fish Wildlife Service, Sacramento, Calif., Cooperative Agreements 14-16-000191514 and 14-16-0001-91515, 96 p. http://www.fws. gov/arcata/fisheries/reports/technical/Spawning_Gravel_ Flushing_During_Trial_Reservoir_Releases_on_the Trinity_River_Field_Observations_and_Recommendations for_Sediment_Maintenance_Flushing_Flows.pdf.

Woolpert, Inc., 2010, Trinity River bathymetry, airborne laser data and photogrammetric DTM merging, verification and certification: Report prepared for Trinity River Restoration Program, U.S. Bureau of Reclamation Task Order R10PD40022, 41 p. http://odp.trrp.net/FileDatabase/ Documents/TRRP_2009_DTM\&ORTHO1.pdf.

Zilliani, L. and Surian N., 2012, Evolutionary trajectory of channel morphology and controlling factors in a large gravel-bed river: Geomorphology, v. 173-174, p. 104-117. doi:10.1016/j.geomorph.2012.06.001. 


\section{Appendix A}




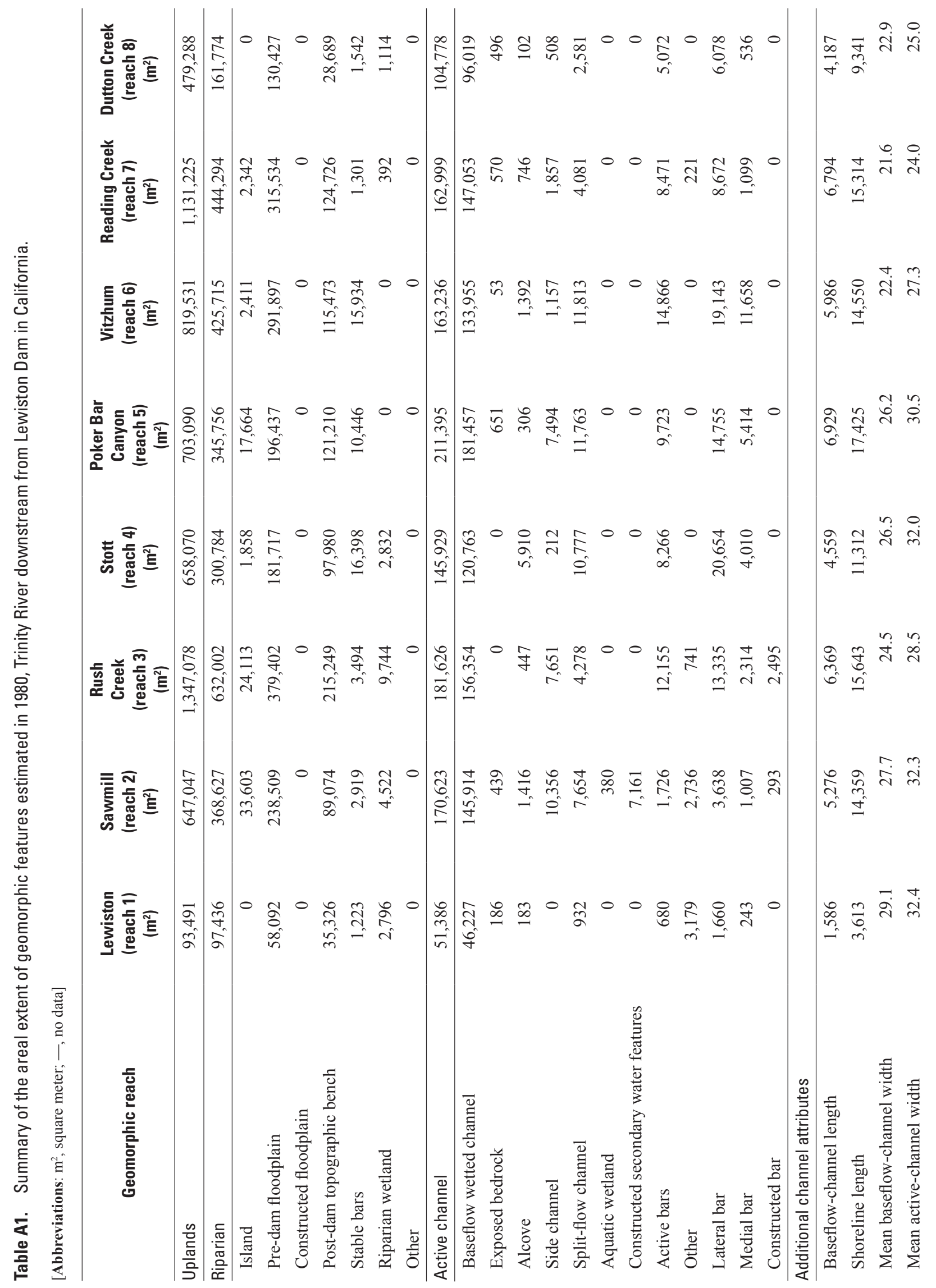




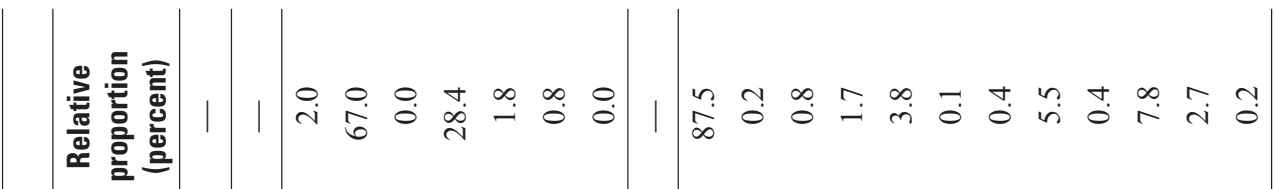

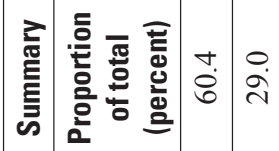

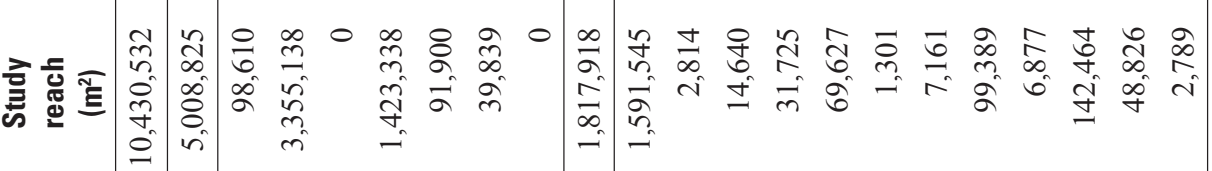

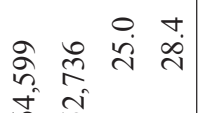

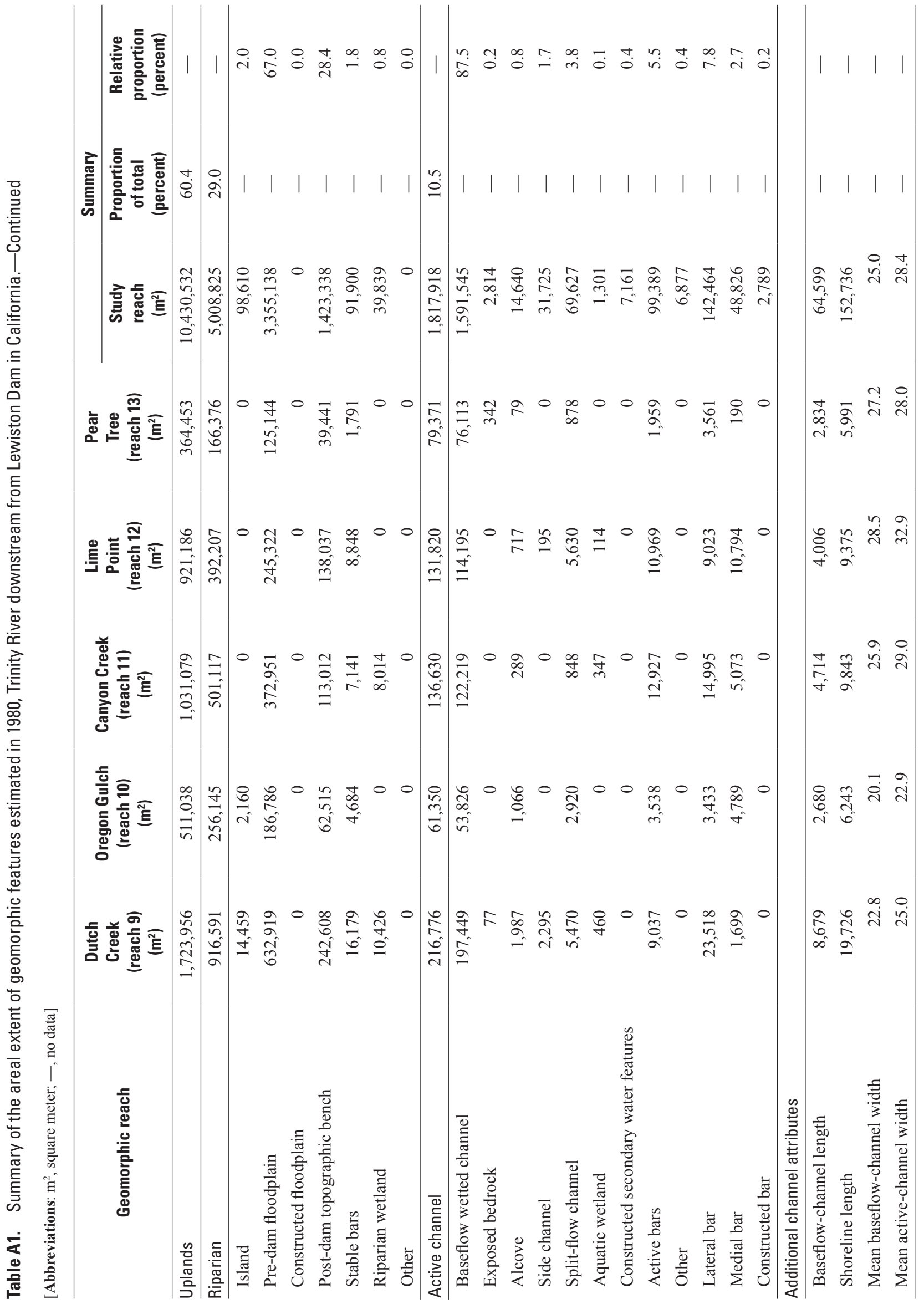




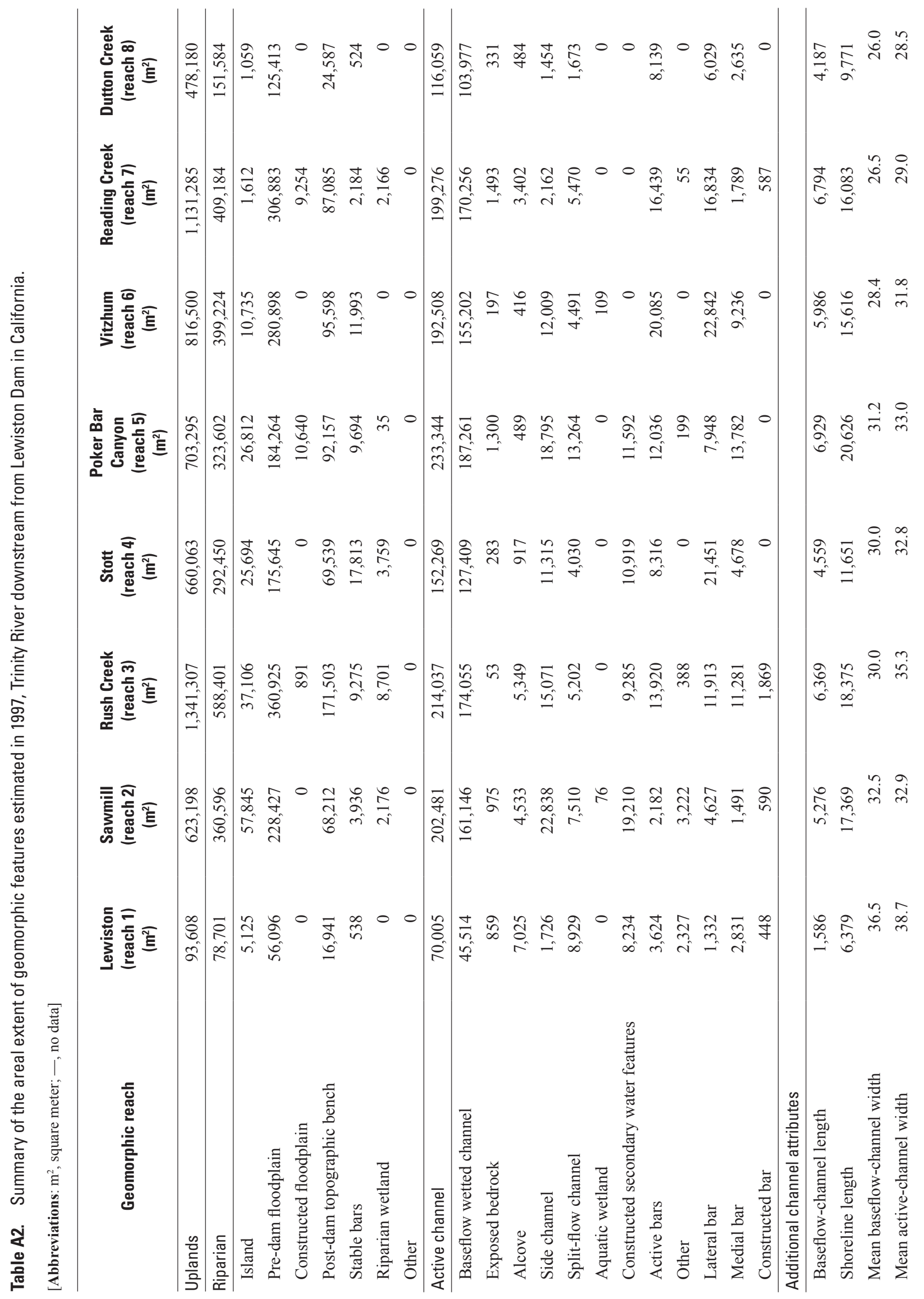




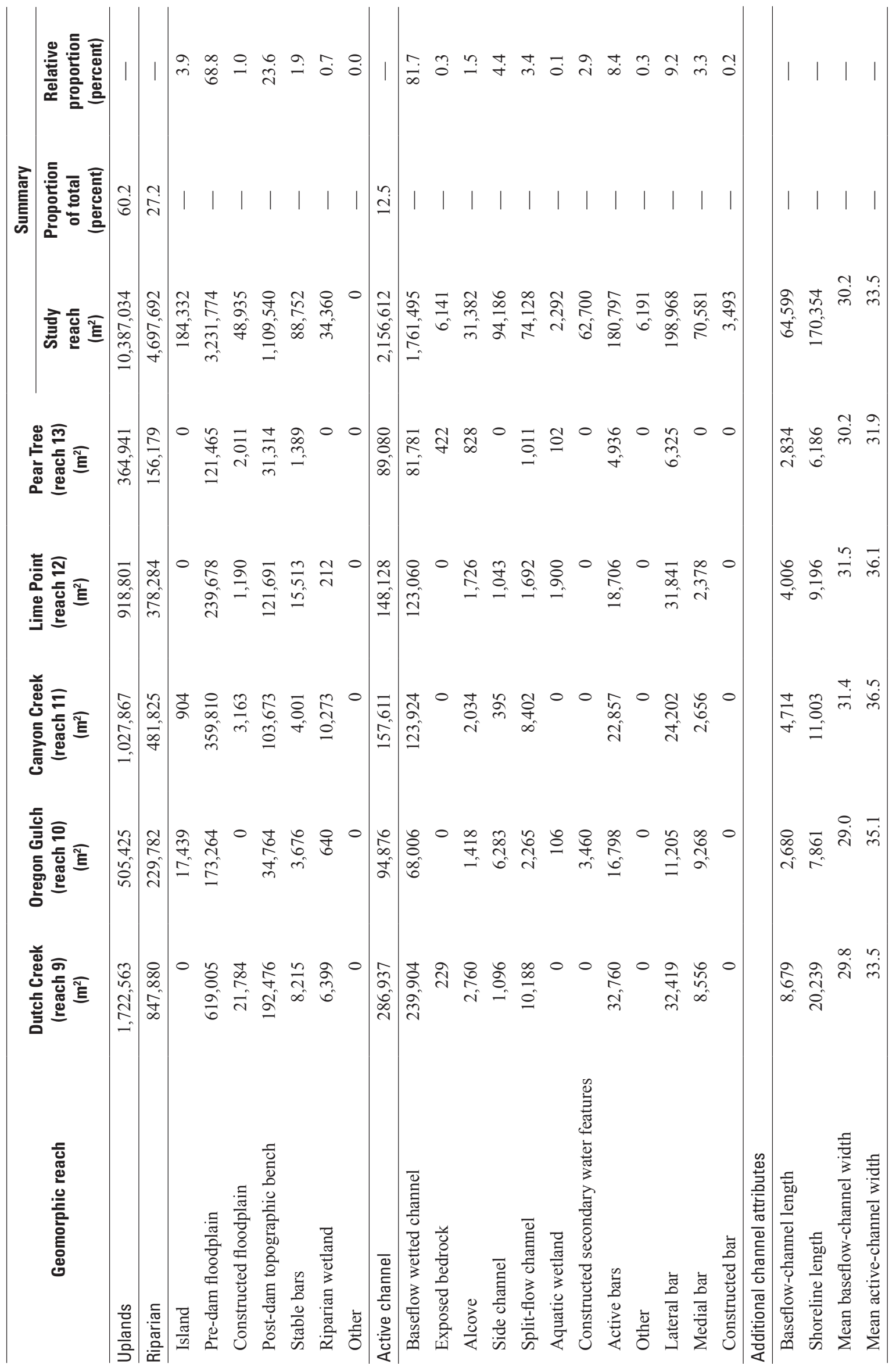




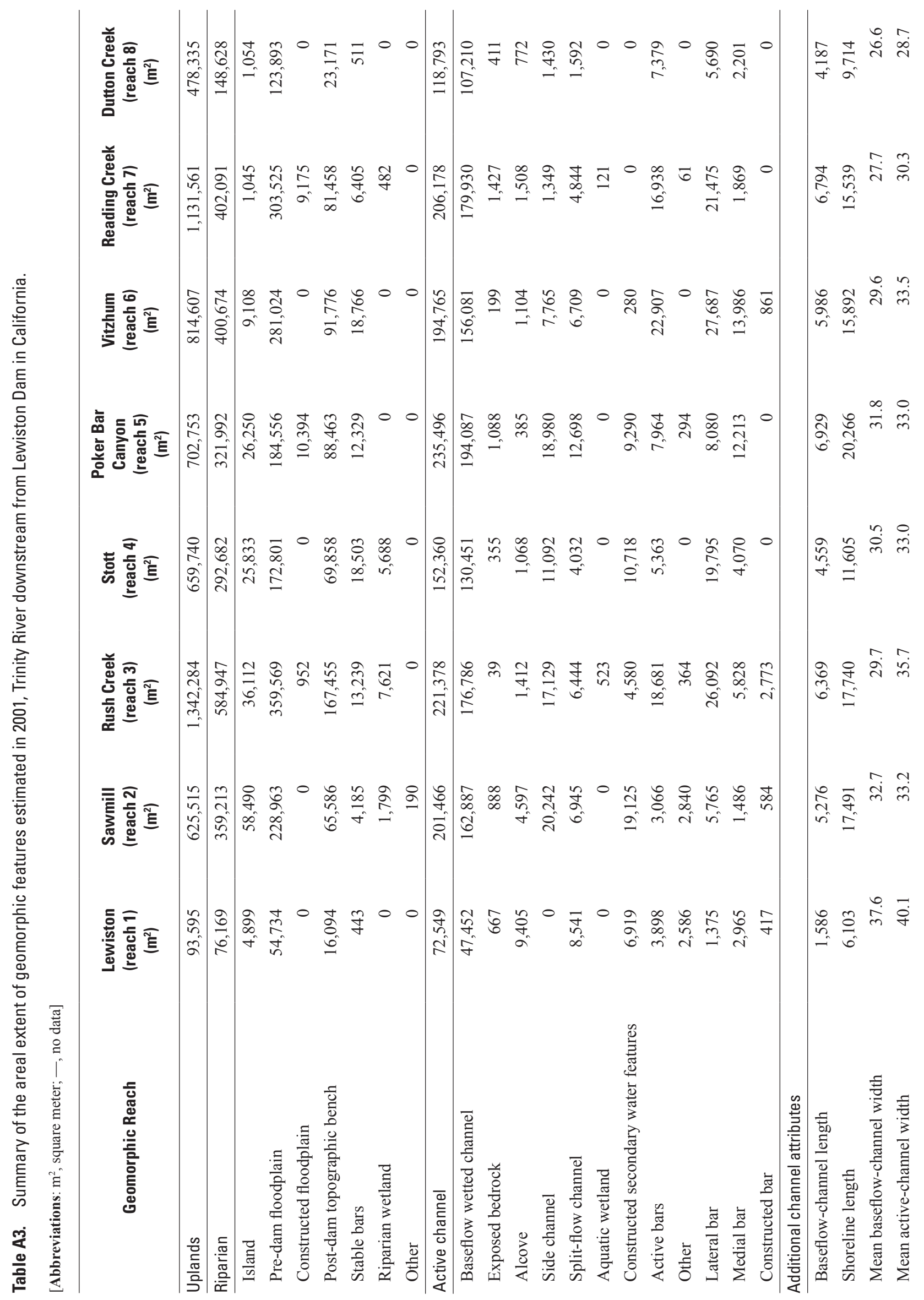




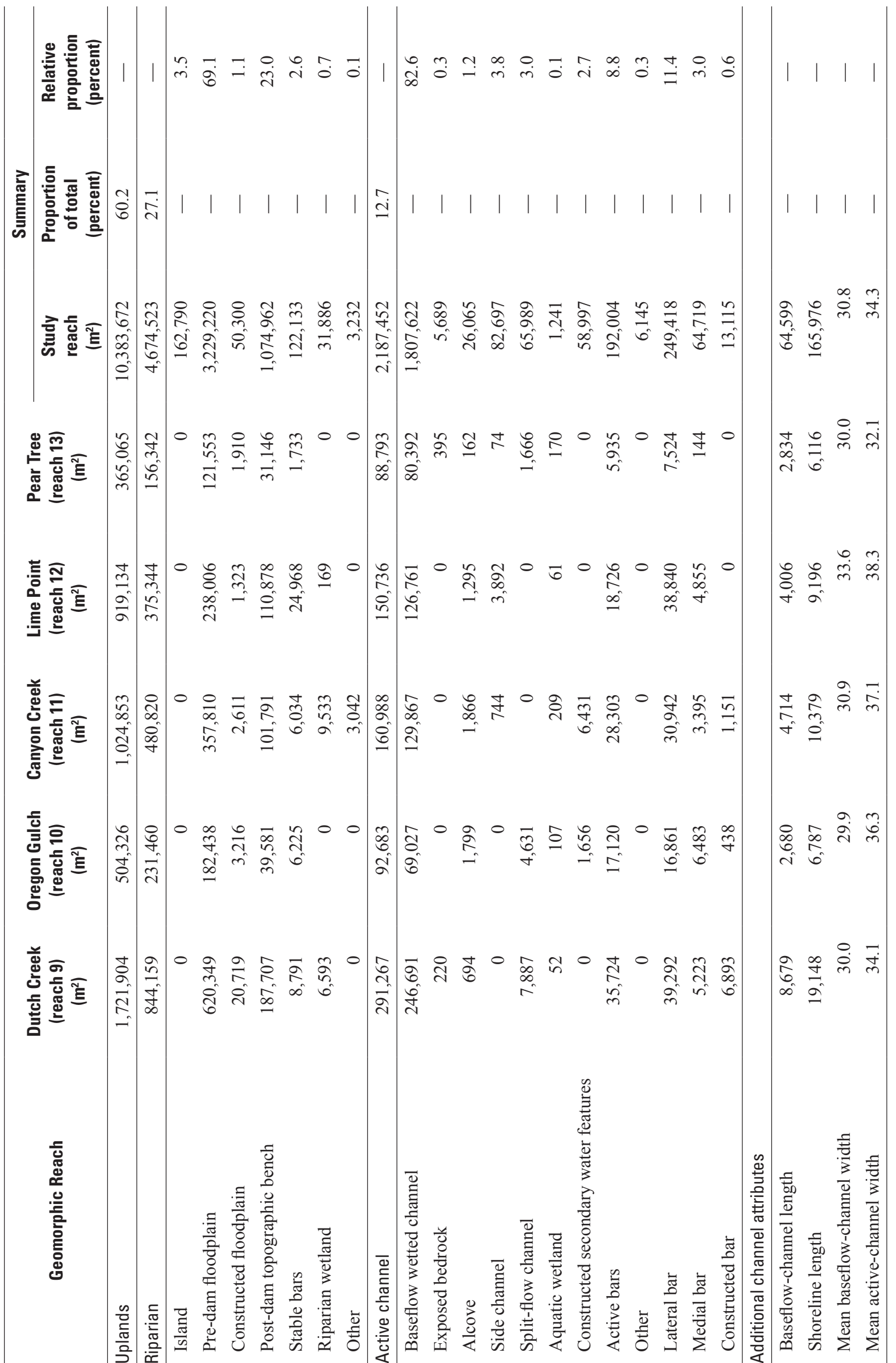




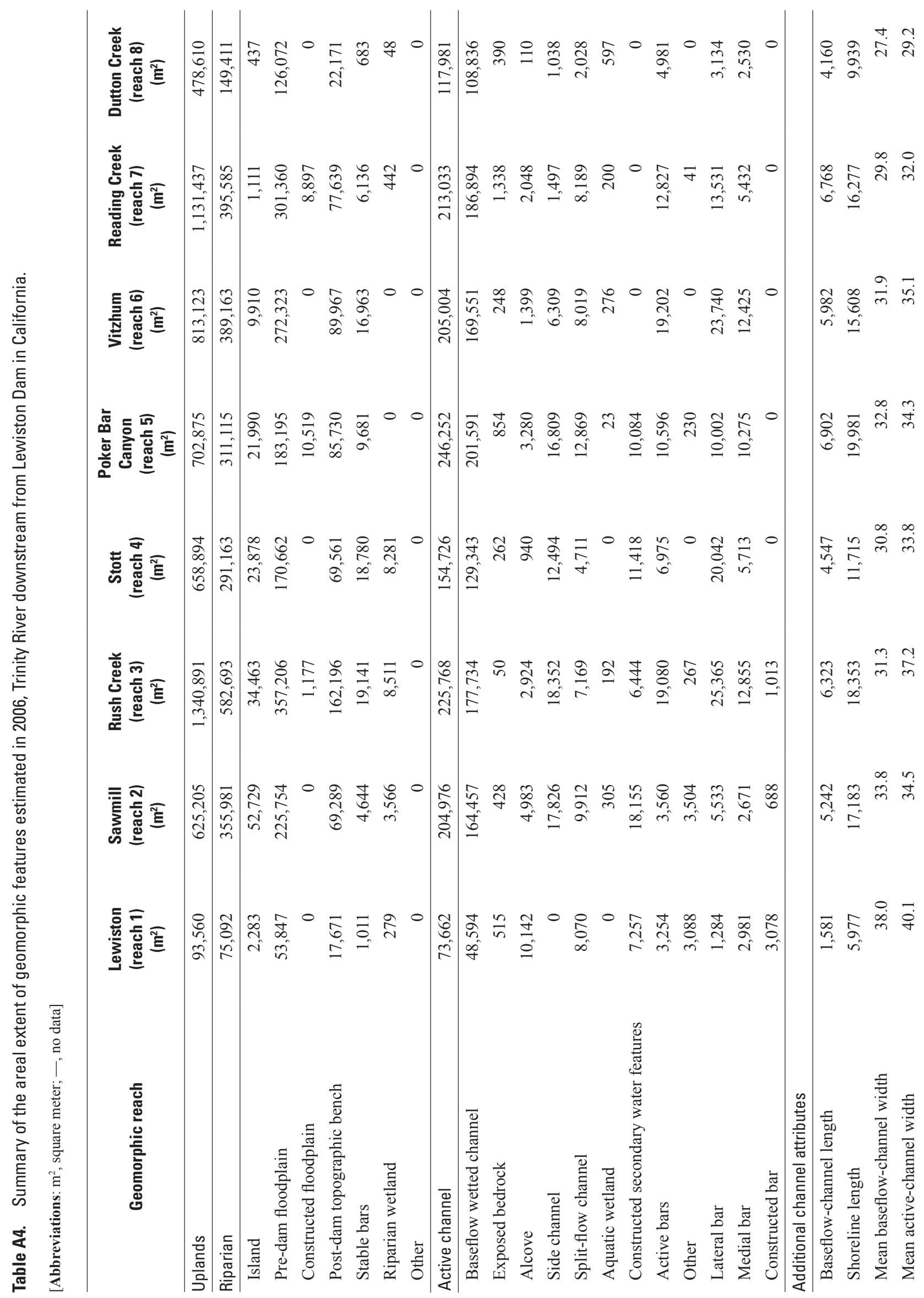




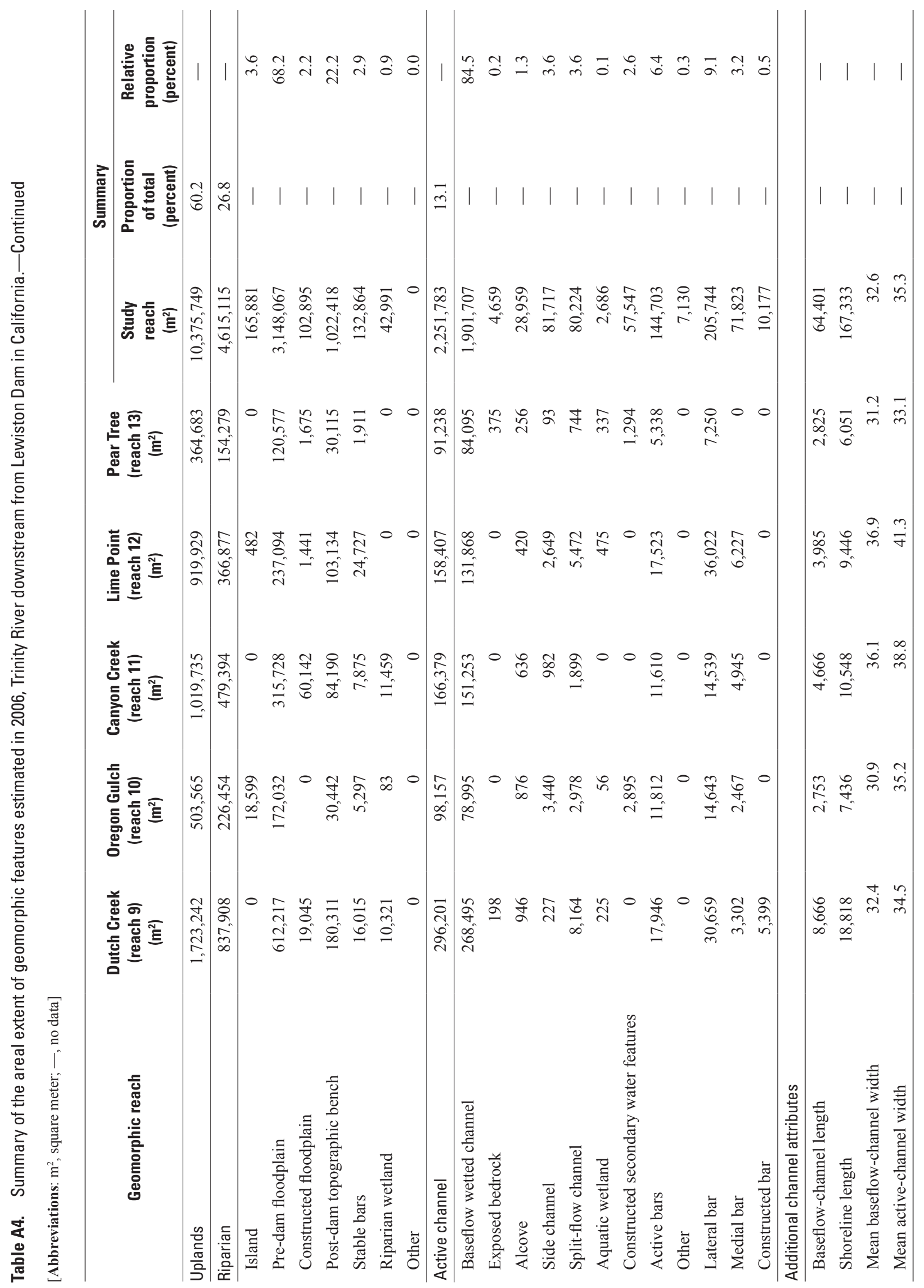




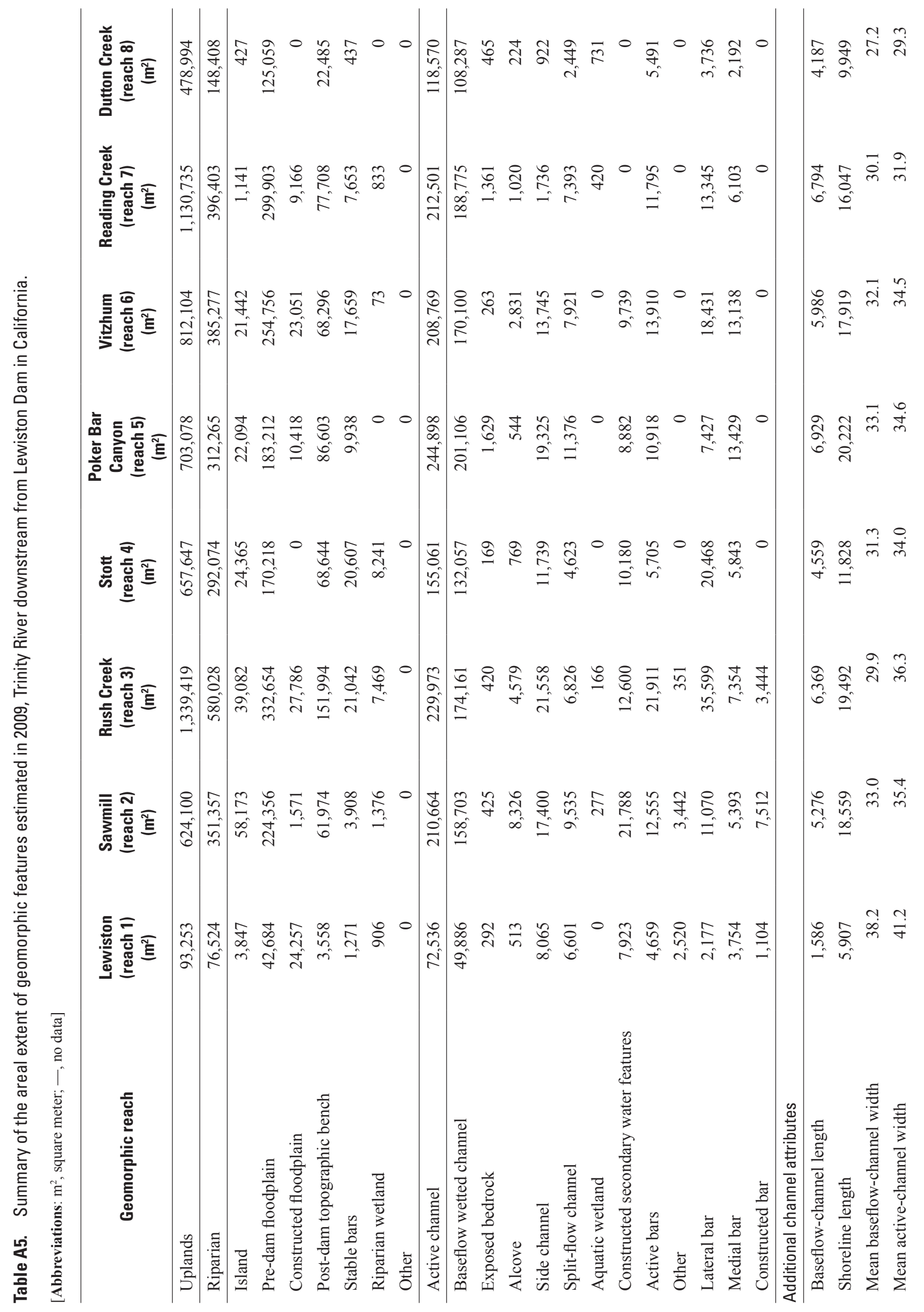




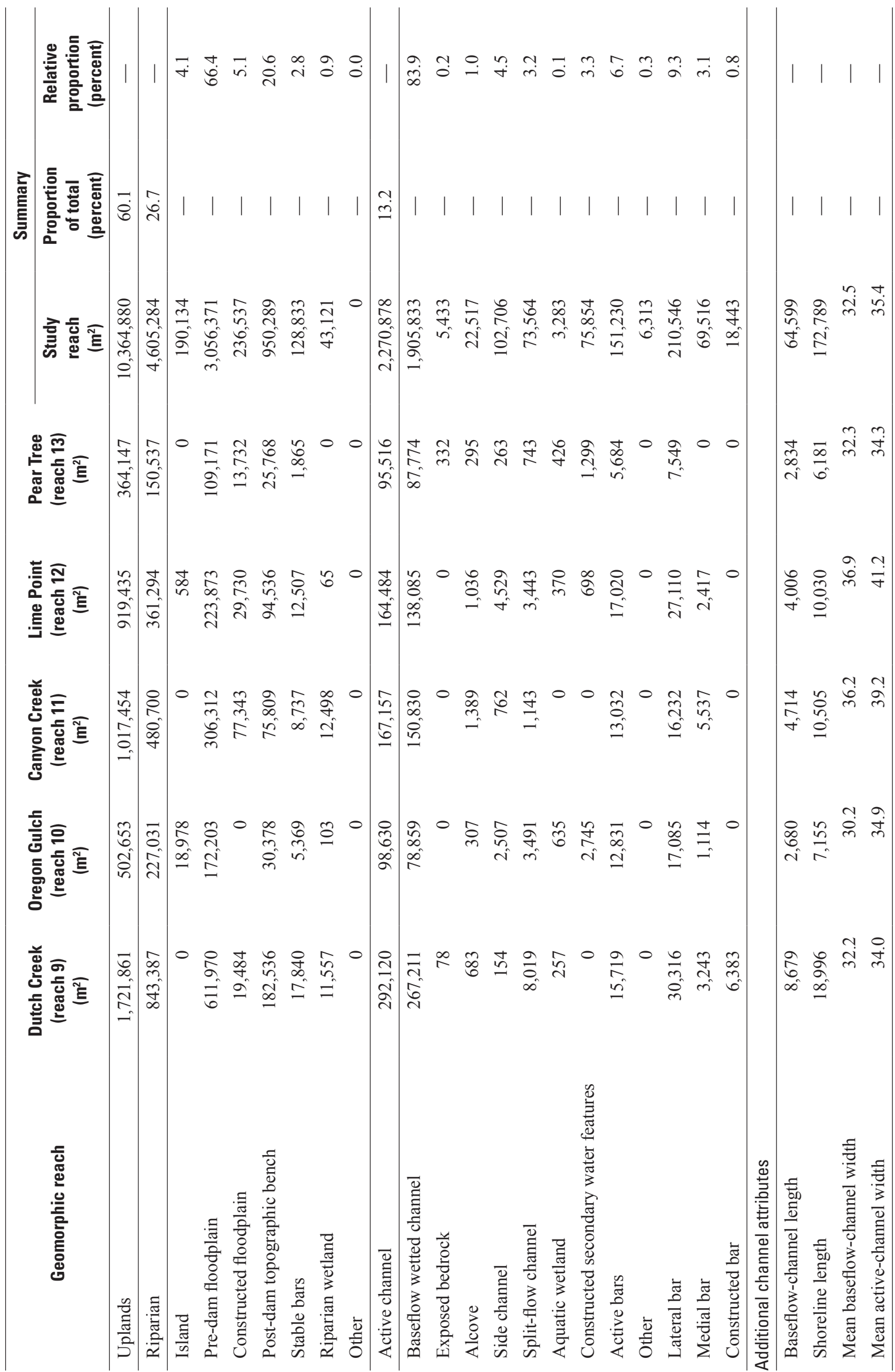




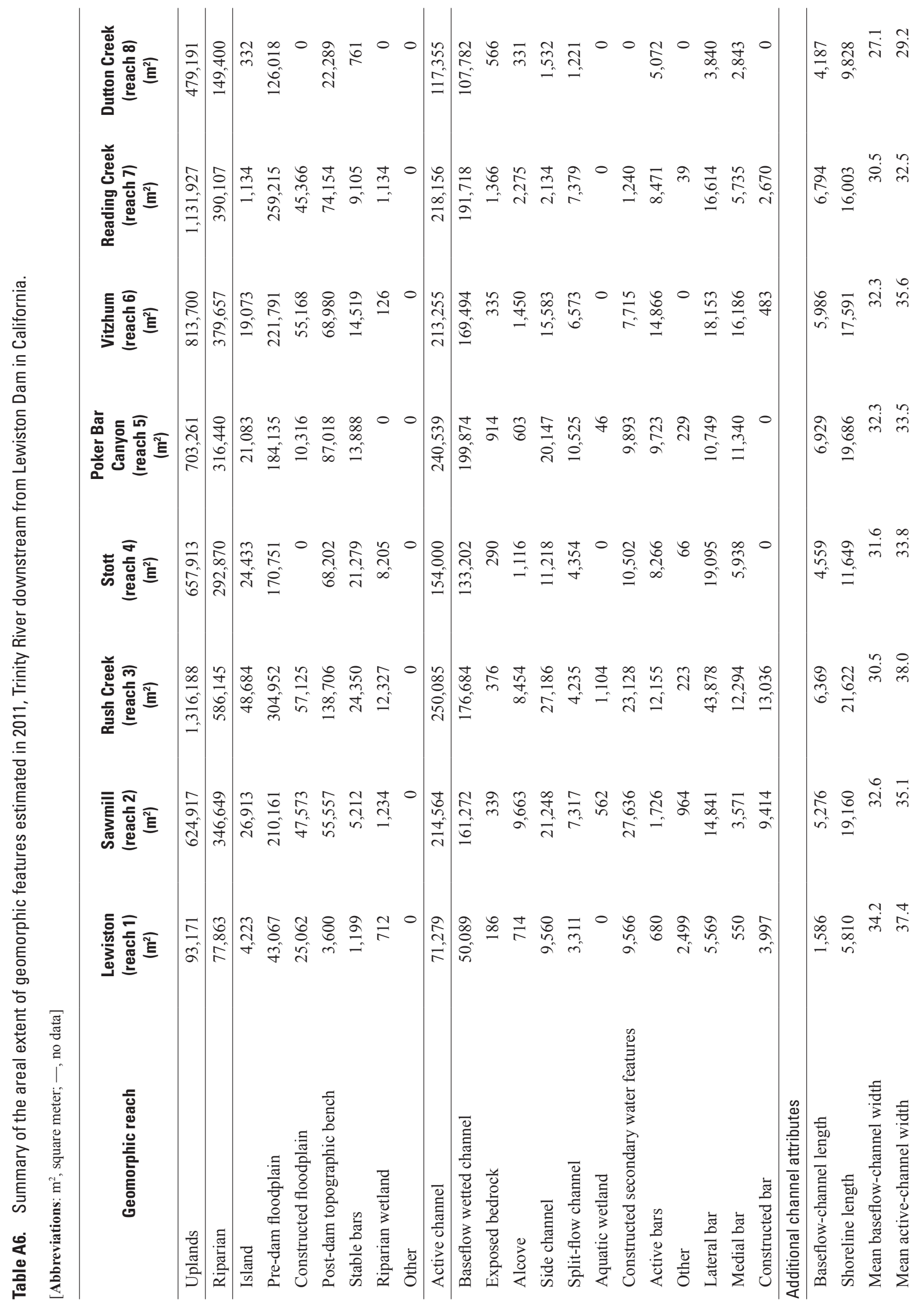




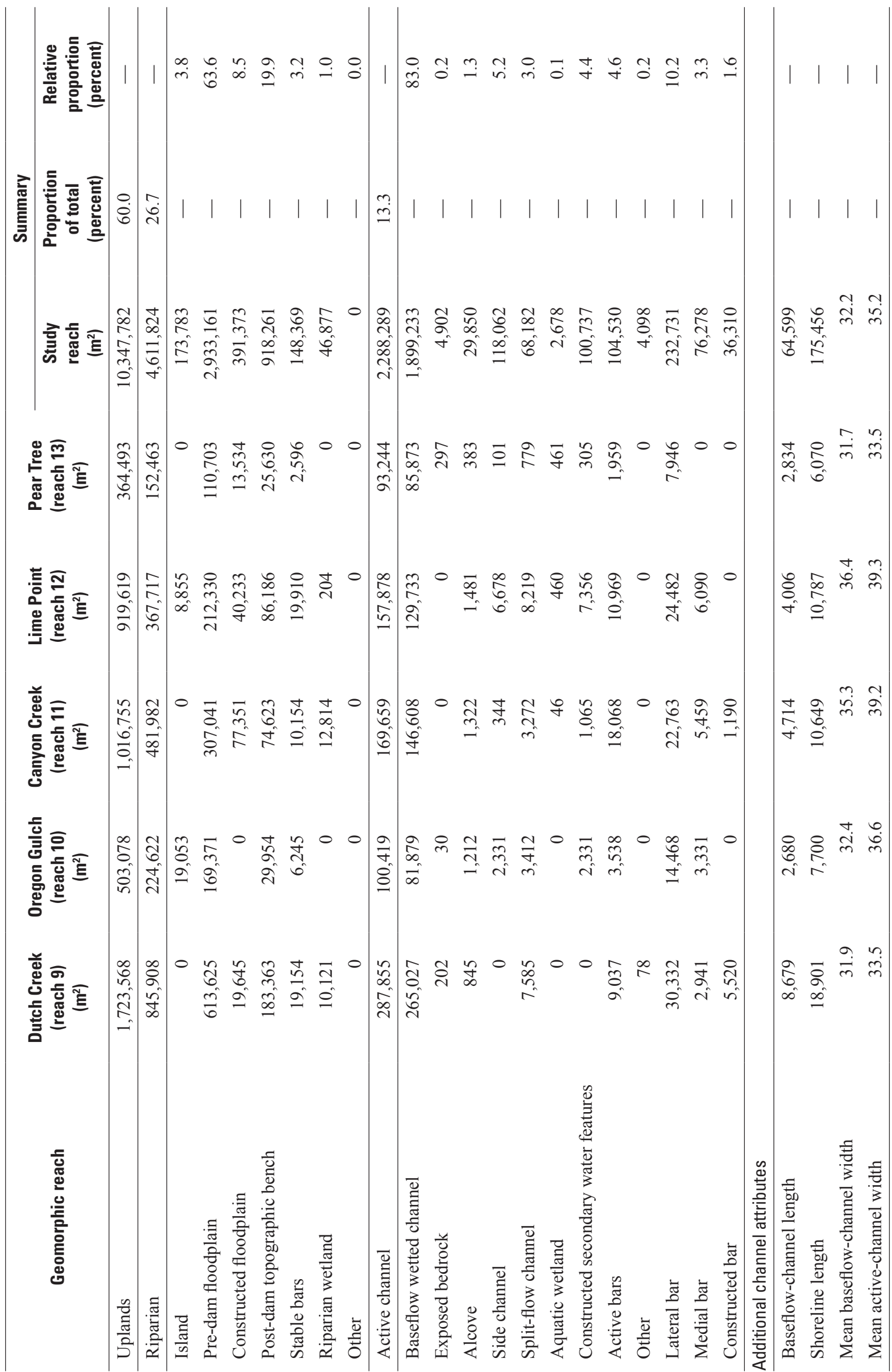



Publishing support provided by the U.S. Geological Survey

Science Publishing Network, Sacramento and Tacoma Publishing Service Centers

For more information concerning the research in this report, contact the

Director, California Water Science Center

U.S. Geological Survey

$6000 \mathrm{~J}$ Street, Placer Hall

Sacramento, California 95819

http://ca.water.usgs.gov 
